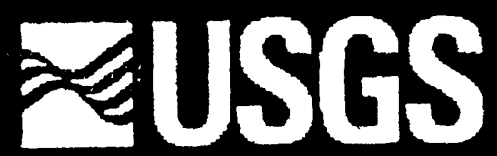

science for a changing world

\title{
A Microearthquake Survey of the Mammoth Mountain Area, Long Valley Caldera, California, Summer 1997
}

By G. R. Foulger 1 , B. R. Julian², D. P. Hill 2 , G. Sharer ${ }^{3}$, L. E. Foulger 4 , R. Perlroth 5 , N. Dotson 6 , A. M. Pitt 2 and E. Brodsky 7

Open-File Report 98-236

1998

This report is preliminary and has not been reviewed for conformity with U. S. Geological Survey editorial standards or with the North American Stratigraphic Code. Any use of trade, product, or firm names is for descriptive purposes only and does not imply endorsement by the U. S. Government.

\section{U.S. DEPARTMENT OF THE INTERIOR}

U.S. GEOLOGICAL SURVEY

' Dept. Geological Sciences, University of Durham, U. K.

2 U.S. Geological survey, Menlo Park, California.

${ }^{3}$ Dept. Geophysics, University of Washington, Seattle.

${ }^{4}$ Liverpool John Moores University, Liverpool, U. K.

5 Tulane University, New Orleans, Louisiana.

6 Dept. Geophysics, Colorado School of Mines, Golden, Colorado.

${ }^{7}$ Seismological Laboratory, Calif. Inst. of Technology, Pasadena, California. 


\section{Introduction and objectives}

This report describes the deployment and operation of a network of 23 digital, three-component seismic stations with closest spacing $\sim 1.5 \mathrm{~km}$ that was deployed on and around Mammoth Mountain, California, from 20 June to 14 Sept., 1997. The primary objectives of the project were twofold. First, to obtain data for tomographic determination of $V_{P}$ and $V_{P} / V_{S}$ around and beneath Mammoth Mountain. A previous tomographic analysis of this volume had been conducted using data collected in 1989 (Julian et al., 1997) on a network of 12 instruments that were deployed opportunistically for a four-day period from 23 to 27 June to monitor an earthquake swarm beneath Mammoth Mountain. This swarm is thought to be associated with the onset of $\mathrm{CO}_{2}$ venting that has killed trees around Mammoth Mountain since 1990. The tomographic analysis revealed a strong negative anomaly in the $V_{P} / V_{S}$ ratio that correlates with the area of surface $\mathrm{CO}_{2}$ venting and may represent the $\mathrm{CO}_{2}$ reservoir. The tomographic analysis for which the current data were collected will be more detailed and of higher quality, will have the power to confirm or otherwise the earlier finding, and yield information on whether the $\mathrm{CO}_{2}$ reservoir has changed size in the intervening eight years.

The second objective was to study the source processes of the long-period (LP) earthquakes that commonly occur about $15 \mathrm{~km}$ beneath the Devil's Postpile, southwest of Mammoth Mountain. These earthquakes may be associated with magma movements, but the existing Northern California Seismic Network (NCSN) data are inadequate for studying source processes because that network is relatively sparse and composed mainly of single-component instruments. The network deployed in the 1997 project remedied these shortcomings.

In addition to these primary objectives, other analyses planned include study of fault-guided waves, anisotropy tomography, accurate relative relocations, and focal mechanisms of highfrequency earthquakes.

\section{Personnel}

The field project was conducted by USGS staff, collaborators and volunteers. In addition, it was greatly extended and enhanced by cooperation with Duke University, which simultaneously deployed a 40-station three-component network immediately to the east of the USGS network. The Duke University group was led by Prof. Peter E. Malin, Division of Earth Sciences, Nicholas School of the Environment, Box 90235, Duke University, Durham NC 27708-0235. 


\section{The equipment}

Table 1 lists the equipment that was used. Each seismic station comprised a seismometer, a Reftek Data Acquisition System (DAS), disk, battery, solar panel and OMEGA or GPS time-code reciever. Of the seismometers deployed, 21 used 2- $\mathrm{Hz}$ Mark Products model L22 sensors, one (Devil's Postpile) used a Guralp 3-ESP broadband seismometer and one (King Creek) used a Guralp 40-T broadband seismometer. The Epson Hand-held Terminals (EHTs) were used to communicate with the DASes, loading parameters into them, starting and stopping data acquisition, and checking instrument status. The palmtop and laptop computers can perform the same functions, and were used as backups in case of EHT failures.

The hand-held GPS reciever was used to check the DAS clocks for rough accuracy and to obtain preliminary station locations. Midway through the experiment, we visited all the stations with the geodetic-quality GPS recievers and recorded radio-frequency phase data, which will be processed to obtain station locations accurate to about one meter.

A Sun workststaion with a 9-Gbyte data disk and a DAT tape drive was installed at the field headquarters. Data were periodically copied from field disks to the computer disk and from there archived to DAT tape and displayed and examined visually for quality control. The Apple Macintosh computer was used for general office tasks such as printing forms and preparing reports.

A 24-bit Reftek DAS was kindly lent by Prof. Paul Davis of UCLA when one of the Caltech DASes malfunctioned. 


\section{Table 1 - Equipment Used}

\section{From the USGS}

30 Mark Products L22 three-component, 2-Hz seismometers

8 10-watt solar panels

35 100-amp hr. lead-acid batteries

2 Ashtech C/A code geodetic GPS receivers

1 Sun Sparcstation 2 workstation with 9 Gbyte data disk and DAT drive

1 Apple Macintosh computer Auxiliary items

From the Natural Environment Research Council (NERC) U. K.

23 Reftek 72A-02 Data Acquisition Systems ( $15 \times 512 \mathrm{~kb}$ RAM, $1 \times 1.5 \mathrm{Mb}, 7 \times 2.5 \mathrm{Mb})$

24 Reftek recording disks $(6 \times 360 \mathrm{Mb}, 1 \times 440 \mathrm{Mb}, 8 \times 540 \mathrm{Mb}, 9 \times 660 \mathrm{Mb})$

3 Reftek 72A-03 Exabyte tape drives

1 Magellan Nav handheld GPS receiver

1 Toshiba T1850 laptop computer

1 Hewlett-Packard Palmtop computer

23 24-watt solar panels

2 Epson EHT-10 handheld terminals

8 Reftek 111A GPS clocks

17 OMEGA preamplifiers and aerials auxiliary cables and items

\section{From Caltech}

2 Reftek 24-bit Data Acquisition Systems

2 Reftek recording disks (170 Mbyte)

2 Reftek GPS clocks

1 Guralp CMG 3-ESP broadband seismometer

1 Guralp CMG 40-T broadband seismometer

1 Laptop computer auxiliary cables

From IRIS-PASSCAL

1 Reftek recording disk (540 Mbyte)

1 SCSI dumping cable

1 GPS clock-DAS cable 


\section{Network design}

Eighteen of the stations were located in an array centered around Mammoth Mountain and having station spacings from about 1 to $2.5 \mathrm{~km}$. Seven of these (Minaret Summit, Boundary Creek, Devil's Postpile, Mammoth Summit, Ski Lifts, North Mammoth Mtn. and Horseshoe Lake) were deployed at or close to sites occupied in the 1989 GEOS deployment, to maintain some similarity between the two networks and facilitate comparison between the 1989 and 1997 tomographic images (Figure 1).

In order to extend coverage of the focal spheres of the deep LP earthquakes, four stations (Thousand Island Lake, Grant Lake, Upper Rock Creek and McGee Moraine) were located at larger distances (up to about $33 \mathrm{~km}$ ) from Devil's Postpile. Access to the area west of Devil's Postpile is legally restricted, so coverage of the corresponding part of the upper focal hemisphere is limited. We enjoyed free exchange of data with the Duke University group, and our networks were each designed to complement each other without overlap or gaps.

One station (Backyard) was operated intermittently next to the field headquarters, primarily for the purpose of testing questionable hardware units.

Two of the stations (Grant Lake and Deadman Creek) were located near stations of the permanent NCSN network, in order to obtain three-component data for comparison with the single-component NCSN records. Of particular interest is determining whether phases routinely identified as $S$ on NCSN records are correctly identified.

\section{Data recording}

Two data streams were recorded at most stations (Table 2).

Stream 1 recorded 100 sps continuously from each of the three sensor components. We recorded continuously rather than in triggered mode because trigger algorithms invariably discard much desirable data. This is particularly true for low-frequency volcanic earthquakes, because they have unusual spectral characteristics and usually lack sudden onsets.

Stream 2 operated in event-triggered mode, recording $10 \mathrm{~s}$ of data at $100 \mathrm{sps}$ from the vertical components. The main reason for recording this stream was not to obtain seismograms, but to obtain a list of times of possible seismic-wave arrivals at each station. These logs were combined after the project and examined for near coincidences, which indicate probable earthquakes. Data for all stations from the corresponding time periods were subsequently automatically extracted from the 80 Gbytes of continuous data. Stream 2 was turned off at a few stations excessive triggering occurred because of cultural or electronic noise. Occasionally, recording was done on DAS channels 4-6 if channels 1-3 malfunctioned.

In addition to conventional seismometer data, we recorded data from the USGS's SacksEvertson borehole dilatometer (stream 3) and the barometer (stream 4) at Devil's Postpile. A separate DAS at Devil's Postpile recorded data at $40 \mathrm{sps}$ from a 2-component horizontal magnetometer and a 2-component horizontal electrical-field sensor. The DAS at Horseshoe Lake also continuously recorded data from a 2-component (horizontal) magnetometer. The magnetometers and the electrical sensor were installed by Sharon Kedar of the USGS, with whom we cooperated. 


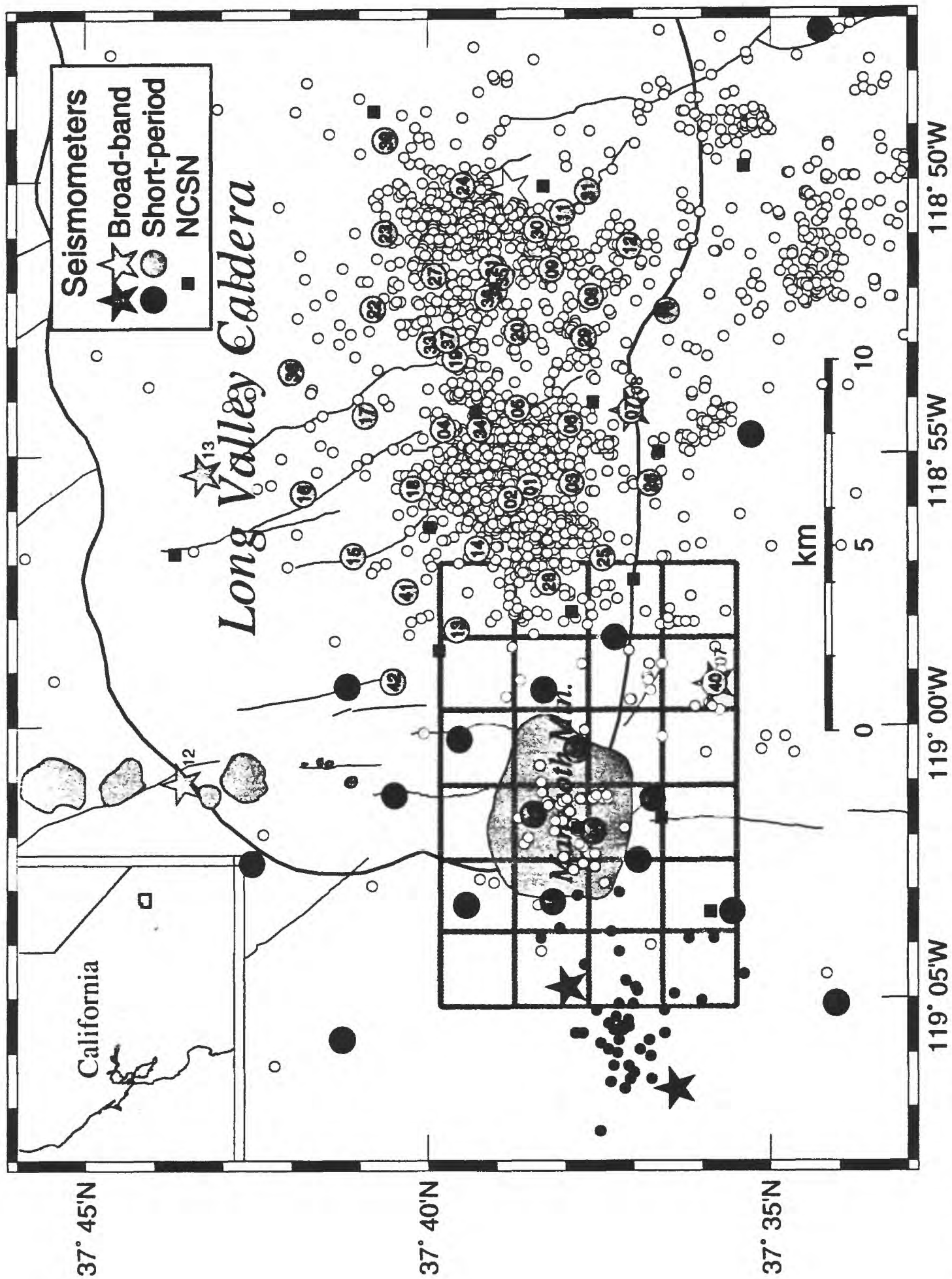

홍

$\stackrel{8}{8}$

iิ่.․․․․․․

통뭉

उ.

कर

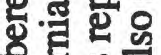

텽 क्षे

之

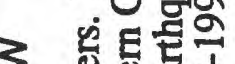

농영

ठ․․ㅇ

증

च

卷记

可放

늘 올

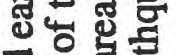

논

ส등

3

ก 웜

$\infty$ 응 녕

들드

홍

통ำ

ํㅝำ

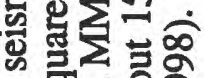

क 명

․ㅇㅁ

3 iूं

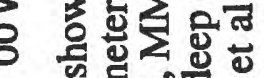

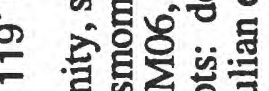

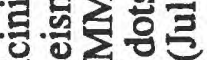

它

등 흥

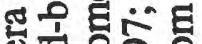

헝영은

궁은드

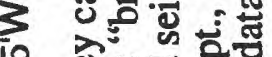

옹 호융

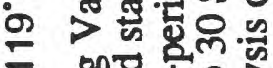

율넌온

용을

통용.

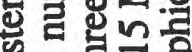

ذiñ

इ क्वे 맹

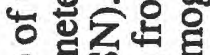

등ํㅇㅇㅇㅇ

运聂至.

$\because$ 幽守

뭉을

일 出

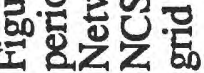


Table 2 - DAS Parameters Used

\begin{tabular}{|c|c|c|c|c|}
\hline \multicolumn{5}{|l|}{ STATION } \\
\hline EXP NUMBR & \\
\hline EXP NAME & & & \multicolumn{2}{|l|}{$\begin{array}{l}\text { MAMMOTH } 97 \\
\text { MAMOT. }\end{array}$} \\
\hline EXP CMMNT & & & \multirow{4}{*}{\multicolumn{2}{|c|}{$\begin{array}{l}\text { different for each site : } \\
\text { different for each site : MM\# }\end{array}$}} \\
\hline STN NUMBR & & & & \\
\hline STN NAME & & & & \\
\hline STN CMMNT & & & & \\
\hline OP MODE & & & \multicolumn{2}{|l|}{$\mathrm{CP} \& \mathrm{SC}$} \\
\hline \multirow{2}{*}{\multicolumn{5}{|c|}{$\begin{array}{l}\text { WAKE UP } \\
\text { START TIM }\end{array}$}} \\
\hline & & & & \\
\hline YEAR & \multicolumn{4}{|c|}{1997} \\
\hline DAY & \multicolumn{4}{|c|}{170} \\
\hline HOUR & \multicolumn{4}{|c|}{00} \\
\hline MINUTES & \multicolumn{4}{|c|}{00} \\
\hline POWER DUR & \\
\hline DAY & \multicolumn{4}{|c|}{99} \\
\hline HOUR & \multirow{2}{*}{\multicolumn{4}{|c|}{$\begin{array}{l}00 \\
00\end{array}$}} \\
\hline MINUTES & \multirow{2}{*}{\multicolumn{3}{|c|}{00}} & \\
\hline \multicolumn{3}{|l|}{ REP INTS } & & \\
\hline \multicolumn{5}{|l|}{ \# OF INTS } \\
\hline \multicolumn{5}{|l|}{ XCK SETUP } \\
\hline LATITUDE & \multicolumn{4}{|c|}{ N37 37} \\
\hline LONGITUDE & \multicolumn{4}{|c|}{ W119 00} \\
\hline CHANNEL & 1 & 2 & 3 & 6 \\
\hline CHAN NAME & $\mathbf{Z}$ & $\mathbf{N}$ & (deactivate) & \\
\hline AZIMUTH & & 0 & 90 & \\
\hline INCLINATN & 90 & $\mathbf{0}$ & 0 & \\
\hline LOCATION & & & & \\
\hline LOCATN X & .1190 & & & \\
\hline LOCATN Y & 3740 & & & \\
\hline LOCATN Z & 2700 & & & \\
\hline UNITS X, Y & $\mathbf{D} \mathbf{M}$ & & & \\
\hline UNITS Z & $\mathbf{M}$ & & & \\
\hline PREAMP & 128 & 128 & 128 & \\
\hline SENS MODL & L22 & $\mathbf{L 2 2}$ & L22 & \\
\hline SENS SERL & different & for eac & site & \\
\hline DATA STRM & 1 & 2 & & \\
\hline STRM NAME & CONT & TRIG & GERS & \\
\hline CHANL \#S & $1,2,3$ & 1 & & \\
\hline SAMP RATE & 100 & 100 & & \\
\hline DATA FORM & 16 & 16 & & \\
\hline TRIG TYPE் & CON & EVT & & \\
\hline TRIG PRMS & & & & \\
\hline TRIG CHS & $\mathbf{1}$ & & & \\
\hline MIN CHIS & & & & \\
\hline TRIG WIND & & & & \\
\hline PRETR LEN & 2 & & & \\
\hline POSTTRG L & & & & \\
\hline RECRD LEN & 1200 & 10 & & \\
\hline NEXT & & & & \\
\hline STA LNGTH & 0.2 & & & \\
\hline LTA LNGTH & 30 & & & \\
\hline MEAN RMVL & 5 & & & \\
\hline TRIG RAT & 4 & & & \\
\hline LTA HOLD & (activate & & & \\
\hline
\end{tabular}




\section{Deployment of the network}

The stations were installed by two field parties working independently, over a period of 13 days. The speed at which the network was installed may be attributed to the close proximity of many stations to our headquarters at Mammoth Lakes (see Table 3 and optional Appendix 1). The sensors were in most cases plastered onto bedrock in the bottoms of shallow pits, covered with dishwashing bowls and buried (Tables 4 and 5). Suitable outcrops were not available at a few stations, and there the sensors were either plastered onto dirt and buried (Corrals, Backyard, McGee Moraine), or a large boulder (Dry Creek) or they were placed on the concrete floor of a shed (Devil's Postpile, Horseshoe Lake). The DAS, disk and battery were covered with twigs, bark and plastic bags for camouflage and protection against the sun and rain. The solar panels were oriented south at small tilt angles. Backyard was installed halfway through the project, primarily as a test site for spares and repaired equipment, though some useful data were recorded there.

The stations that were accessible by vehicle ( 18 out of 23 ) mostly had OMEGA timing and were powered by a single 100-ampere-hr. battery and a 24-watt solar panel. The 6-foot OMEGA whip antennas were clamped to 3-foot lengths of steel reinforcing rod, which had been driven into the ground. The GPS clocks were covered with plastic bags and buried with their antennas exposed above ground level. OMEGA reception was intermittent at some sites amongst trees, and at Earthquake Fault and Red's Lake several antenna sites in the vicinity of the DAS had to be tried before adequate reception was obtained. At Upper Rock Creek, OMEGA reception was never achieved and so the OMEGA DAS deployed there was exchanged for a GPS unit. At no sites did we experience difficulty in receiving the GPS signal.

Driving is forbidden west of Devil's Postpile, most of which is Wilderness area, and access is allowed only by foot or hoof. Because funding was not available for helicopters, we installed and serviced five sites by hiking round-trip distances of up to 16 miles (Boundary Creek, Red Cones, Cold Creek, King Creek and Thousand Island Lake). Pack mules were used when large amounts of heavy equipment had to be taken to the sites, e.g., for the installation and retrieval of the stations. These five hiking stations were each powered by two 100 -amp. hr. batteries and multiple solar panels (see Section 7).

Thousand Island Lake and King Creek were installed at the earliest possible dates, when snow melting rendered the trails open to mules. Thus King Creek was installed on $8 \mathrm{July}$, a week later than the other stations. The trail was only marginally passable then, as a flood had destroyed the crossing of King Creek during the previous winter. It was only with difficulty that the field party

struggled across at a ford downstream, and it was with even more difficulty that the horses and mules crossed at a ford further upstream. 


\section{Table 3 - List of Stations}

3-ESP and 40-T: Guralp broadband seismometers. L22: Mark Products 2-Hz seismometers. Bold type: stations that require substantial hikes for access, and for which mules were hired to pack in the equipment for station installation and retrieval. See optional Appendix 1 for detailed site descriptions.

\begin{tabular}{|c|c|c|c|c|}
\hline Stat \# & Station name & $\begin{array}{c}\text { Sensor } \\
\text { type }\end{array}$ & $\begin{array}{c}\text { Date } \\
\text { installed }\end{array}$ & Accessibility \\
\hline & & & & \\
\hline 1 & Devils Postpile & 3-ESP & 20 June & In shed, $\sim 12$-mi drive, 100 -meter walk \\
\hline 2 & Earthquake Fault & L22 & 20 June & -5-mi drive, 50-meter walk from 4WD trail \\
\hline 3 & Ski Lifts & $\mathrm{L} 22$ & 21 June & -5-mi drive, 10 -meter walk from 4WD trail \\
\hline 4 & Corrals & L22 & 21 June & -4-mi drive, 15-meter walk from dirt road \\
\hline 5 & Minaret Summit & $\mathrm{L} 22$ & 22 June & -5-mi drive, 220 -meter walk \\
\hline 6 & Grant Lake & $\mathrm{L} 22$ & 24 June & 45-min drive, 50 meters from $4 \mathrm{WD}$ trail \\
\hline 7 & Backyard & L22 & 30 July & Down a flight of stairs \\
\hline 8 & Thou. Island Lake & L22 & 2 July & -10-mi drive, 3-hr hike \\
\hline 9 & King Creek & $40-\mathrm{T}$ & 8 July & -12-mi drive, 2-hr hike \\
\hline 10 & Agnew Meadows & $\mathrm{L} 22$ & 24 June & -10-mi drive, 20 meters from dirt road \\
\hline 11 & Crater Flat & L22 & 23 June & -5-mi drive, 50 meters from $4 \mathrm{WD}$ trail \\
\hline 12 & North Mammoth Mtn & L22 & 23 June & -5-mi drive, 50-meter climb from 4WD trail \\
\hline 13 & Reds Lake & L22 & 23 June & -5-mi drive, 20-meter walk \\
\hline 14 & Mammoth Summit & L22 & 26 June & $\sim 5$-mi drive, gondola ride, 500-meter walk \\
\hline 15 & Cold Creek & L22 & 27 June & 40-min drive, 1.25-hr hike \\
\hline 16 & Imaginary station & & & \\
\hline 17 & Red Cones & L22 & 25 June & $\sim 4$ mile drive, 1-hr hike \\
\hline 18 & Horseshoe Lake & $\mathrm{L} 22$ & 1 July & In hut, $\sim 4$ mile drive, 100 meter walk \\
\hline 19 & Boundary Creek & $\mathrm{L} 22$ & 25 June & -4-mile drive, 45-min hike \\
\hline 20 & Laurel Canyon & L22 & 24 June & $\begin{array}{l}\text { 4-mile drive, 3-mile 4WD, 30-meter } \\
\text { scramble }\end{array}$ \\
\hline 21 & McGee Moraine & L22 & 24 June & 100-mile drive, 20 -meter walk \\
\hline 22 & Dry Creek & $\mathrm{L} 22$ & 30 June & $\sim 5$-mi drive, no walk \\
\hline 23 & Upper Rock Creek & $\mathrm{L} 22$ & 26 June & $\sim 1$-hr drive, 30-meter scramble \\
\hline 24 & Deadman Creek & L22 & 22 June & -30-min drive, 20-meter scramble \\
\hline
\end{tabular}

Mule pack stations used for installation of remote stations

Red Cones/Boundary Creek: $\quad$ Mammoth Lakes Pack Outfit, tel. 760/934-2434

Thou. Isl. Lake, King Creek, Cold Creek : Red's Meadow Pack Station, tel. 760/934-2345 


\section{Table 4 - Station Installation Instructions}

\section{STATION SETUP}

**Write down sensor serial number**

\section{VAULT}
a. Dig pit about $1.5 \mathrm{ft}$ deep to bedrock.
b. Pour plaster pad, smooth it and draw magnetic north line.
c. Install seismometer, level it, place stone on cable so seismometer cannot be jerked.
d. Cover with blue plastic basin.

\section{RECORDER}
a. Connect DAS and disk with power and SCSI cables.
b. Connect seismometer to DAS. Use data port labeled 1-3.
c. Set up Omega or GPS timing and connect to DAS.
d. Set up solar panel and connect to battery.
e. Connect DAS power cable to battery.
f. Power up DAS.

\section{LOADING THE PARAMETERS AND STARTUP}

a. Load/check parameters in EHT against those on printed sheet.

b. Add STATION/STN NUMBR, STATION/STN NAME and

CHANNEL/SENS SERL to parameters in EHT.

c. Plug EHT into DAS and perform the following operations:

COMMNCTNS/SEND PRMS/YES

UTILITIES/NEXT MENU/FRMT SCSI/DISK/YES

NEXT MENU/CLEAR RAM/YES

PREV MENU/SYS RESET/YES

TIME

MONITOR/2/ $\{4,5,6\}$
Check time is $O K$

Stomp test

COMMNCTNS/START ACQ/0/0/YES

d. Bury seismometer.

e. Fill in Station Setup Report form before leaving the site. 
Table 5 - Station Setup Report

\section{MAMMOTH MOUNTAIN FIELD PROJECT 1997 \\ STATION SETUP REPORT}

\begin{tabular}{|l|l|l|}
\hline \multicolumn{1}{|c|}{ ITEM } & STATUS & \multicolumn{1}{c|}{ COMMENTS } \\
\hline Station number/name & & \\
\hline Date \& time (GMT) & & \\
\hline Personnel & & \\
\hline Sensor type \& S/N & & \\
\hline GPS/OMEGA S/N & & \\
\hline DAS S/N & & \\
\hline Disk S/N & & meter: \\
\hline Battery voltage & volts: & \\
\hline Label disk: station no. \& name, day & Done? & \\
\hline COMMNCTNS/SEND PRMS/YES & OK? & \\
\hline UTILITIES/FRMT SCSI/DISK/YES & OK? & \\
\hline UTILITIES/CLEAR RAM/YES & OK? & \\
\hline UTILITIES/SYS RESET & OK? & \\
\hline MONITOR/Channel & $1 ? \quad 2 ? \quad 3 ?$ & \\
\hline COMMNCTNS/START ACQ/0/O/YES & & \\
\hline UTC & & \\
\hline ACQ & & \\
\hline EVENTS/MEM US/MEM AV & & \\
\hline UTILITIES/XCLK STAT & & \\
\hline & LAST LK TIME: & \\
\hline Departure time & & \\
\hline
\end{tabular}

STATION LOCATION (Describe, with map if appropriate) \& OTHER COMMENTS: 
Table 6 - Station Service Report

MAMMOTH MOUNTAIN FIELD PROJECT 1997

STATION SERVICE REPORT

\begin{tabular}{|c|c|c|}
\hline ITEM & STATUS & COMMENTS \\
\hline \multicolumn{3}{|l|}{ Station number/name } \\
\hline Date \& time (GMT) & & day of year: \\
\hline \multicolumn{3}{|l|}{ Personnel } \\
\hline \multicolumn{3}{|l|}{ DAS S/N } \\
\hline \multicolumn{3}{|l|}{ Old disk S/N \& size } \\
\hline \multicolumn{3}{|l|}{ New disk S/N \& size } \\
\hline Battery voltage & volts: & meter. \\
\hline \multirow[t]{4}{*}{ Sensor offsets (for Guralps) } & volts/reset? & \\
\hline & V: & \\
\hline & N/S: & \\
\hline & E/W: & \\
\hline UTILITIES/DAS STATE & CP +SCSI? & \\
\hline \multicolumn{3}{|l|}{ UTC } \\
\hline \multicolumn{3}{|l|}{ ACQ } \\
\hline EVENTS/MEM US/MEM AV & & Events/day: \\
\hline \multicolumn{3}{|l|}{ UTILITIES/XCLK STAT } \\
\hline \multicolumn{3}{|l|}{ LAST LK TIME: } \\
\hline COMMUNCTNS/STOP ACQ/YES & ok? & \\
\hline UTILITIES/DAS STATE & ACQ: & \\
\hline \multicolumn{3}{|l|}{ UTILITIES/SCSI STAT } \\
\hline USED/AVAI/TOTL & & $\begin{array}{l}\text { Mbytes/day: } \\
\text { Est. swap date: }\end{array}$ \\
\hline \multicolumn{3}{|l|}{ Swap recording disks } \\
\hline Label disks : station no. \& name, days & done? & \\
\hline UTLLITIES/FRMT SCSIDISK/YES & ok? & \\
\hline UTILITIES/CLEAR RAM/YES & ok? & \\
\hline UTILITIES/SYYS RESET & ok? & \\
\hline \multicolumn{3}{|l|}{ COMMNCTNS/START ACQ/0/0/YES } \\
\hline \multicolumn{3}{|l|}{ UTC } \\
\hline \multicolumn{3}{|l|}{$\mathrm{ACQ}$} \\
\hline COMMUNCTNS/STOP ACQ/YES & ok? & \\
\hline UTILITIES/DAS STATE & ACQ: & \\
\hline \multicolumn{3}{|l|}{ COMMNCTNS/START ACQ/0/0/YES } \\
\hline \multicolumn{3}{|l|}{ UTC } \\
\hline \multicolumn{3}{|l|}{ ACQ } \\
\hline \multicolumn{3}{|l|}{ EVENTS/MEM US/MEMAV } \\
\hline Departure time & & \\
\hline
\end{tabular}

Cont. overleaf? 


\section{Power}

Each station that could be accessed by vehicle was powered by a 100-amp hr. lead acid battery and a single 24-watt solar panel. Station 7 (Backyard) was operated without a solar panel and required battery changes about every four days.

The performance of the solar panels was highly variable. Despite the fact that the weather was very sunny and the skies clear most of the time, in only three cases could the solar panels keep the batteries charged. Battery changes had to be made with frequencies that varied greatly between stations from every five days to never (Figure 2). Comparison with the battery performance at Backyard illustrates that at some stations little was gained by deploying solar panels under our conditions. Much of the explanation for the variability of performance of the solar panels must lie in the facts that some stations were located in forests where trees obscured much of the sky, and cloud cover tended to increase from east to west across the network. However, at some sites these factors did not appear to explain fully the requirement for battery changes. Other reasons, e.g., variability in the solar panels, internal resistance in the solar panel wires, or quality of the batteries (ours were not new) may also have played a part.

Each of the five stations that required hikes was equipped with two 100 -amp. hr. batteries and solar panels rated at a total of 48 watts (except that Boundary Creek was provided with 60 watts and Thousand Island Lake with 44 watts). This was adequate to power those stations without battery changes except in the case of Boundary Creek, which was located in thick forest. At that station a single replacement battery was backpacked in every 22 days.

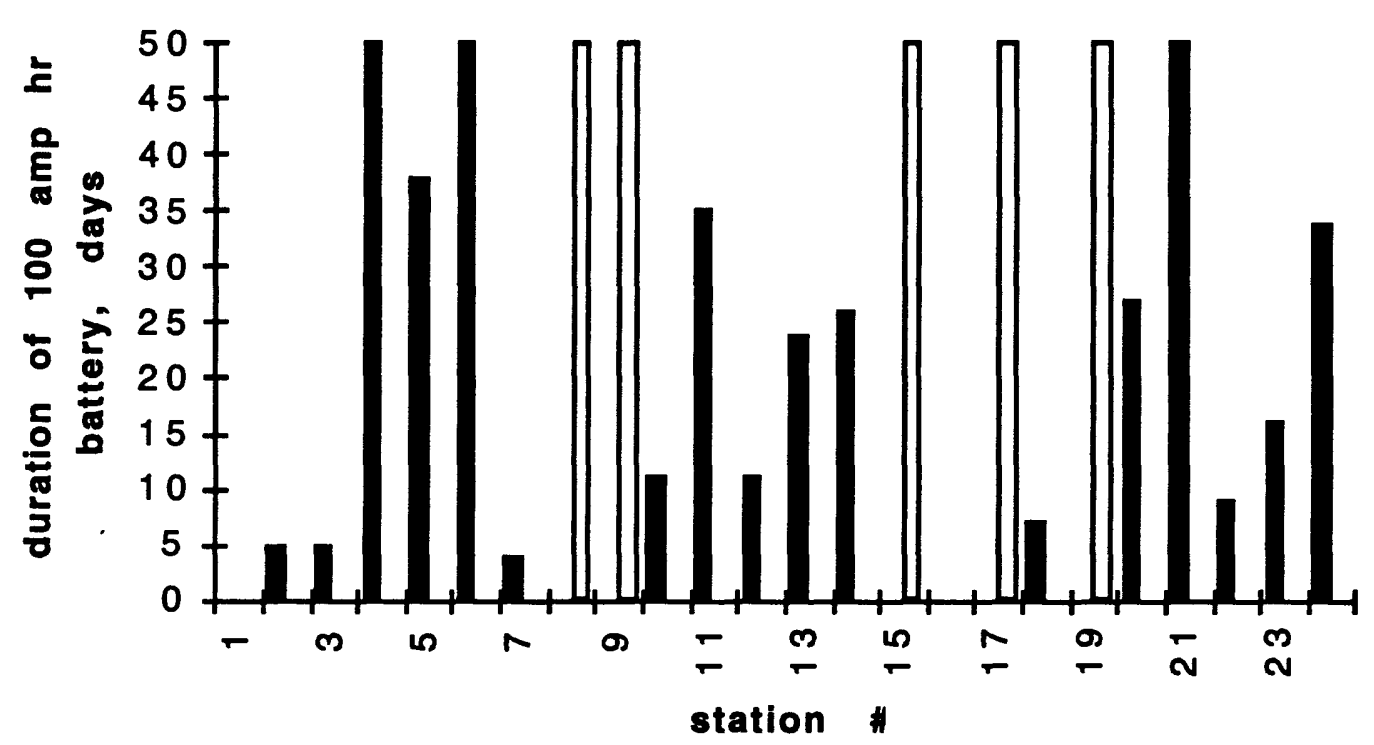

Figure 2: Plot of station \# vs. typical interval between battery changes. Black bars: stations powered by a single 100-amp hr battery and a 24-watt solar panel and station 7 (Backyard). Stations where the solar panels kept the batteries fully charged are indicated as lasting 50 days. Station 1 was powered by mains electricity. Station 7 had no solar panel and provides a useful comparison. Stations 8, 9, 15, 17 and 19 (white bars), which required hikes, were each powered by two 100 -amp hr batteries and two solar panels, which was adequate to avoid battery changes in all cases except station 19, where a battery was occasionally packed in. Station 16 did not exist. 


\section{Servicing the stations}

Each station recorded about 53 Mbytes of data per day. Thus the disks lasted 3-11 days depending on their capacity. Batteries had to be changed as often as every five days, and thus both these factors were taken into account in designing the station servicing schedule.

Servicing a station involved filling out a station service report (Table 6) and performing actions in order as listed there. The functioning of the DAS and time-signal locking was checked, acquisition was stopped and the amount of data recorded noted. The disk was then changed (and the battery if necessary), acquisition was restarted and the correct functioning of the DAS was checked before departing.

Deciding whether a battery should be changed was severely complicated by the fact that we were using solar panels that provided partial power. If the battery voltage was measured when the solar panel was in full sun or had been so recently, a high voltage was measured that did not reflect the true level of charge in the battery. Furthermore, as the disks were of varying size, batteries had to last anywhere between 3 and 11 days between station visits. Lastly, whether or not the solar panels would perform well over the next few days was dependent on the weather, which was sometimes overcast. Confusion over these issues, and our initial expectation that the solar panels would be able to fully power the stations, resulted in some data loss early in the project. We eventually designed the following modus operandi for station-servicing parties, which worked in virtually all cases.

1. On arrival at station, disconnect or cover the solar panel.

2. After stopping acquisition, about 10 mins later, measure the voltage.

3 . If the voltage is $<12.4 \mathrm{v}$, change the battery before restarting acquisition.

4. If the solar panel is in full sun and cannot be covered, change battery if the voltage is $<12.7 \mathrm{v}$.

The station locations were all surveyed using if-phase differential GPS towards the end of the deployment period (Table 7). 
Table 7 - Geodetic Coordinates of Stations (Datum: WGS 84)

\begin{tabular}{lllll}
\hline Code & Latitude & Longitude & $\begin{array}{l}\text { Elev. } \\
(\mathrm{m})\end{array}$ & Name \\
\hline MM01 & $37: 37.9751$ & $-119: 04.7861$ & 2182 & Devils Postpile \\
MM02 & $37: 39.5454$ & $-119: 00.2589$ & 2578 & Earthquake Fault \\
MM03 & $37: 37.8369$ & $-119: 00.4402$ & 3056 & Ski Lifts \\
MM04 & $37: 37.2758$ & $-118: 58.3985$ & 2411 & Corrals \\
MM05 & $37: 39.4470$ & $-119: 03.3179$ & 2886 & Minaret Summit \\
MM06 & $37: 50.0679$ & $-119: 07.7541$ & 2528 & Grant Lake \\
MM07 & $37: 38.3018$ & $-118: 59.3483$ & 2585 & Back Yard \\
MM08 & $37: 43: 48$ & $-119: 10: 11$ & 2982 & Thousand Island Lake \\
MM09 & $37: 36: 23$ & $-119: 06: 38$ & 2546 & King Creek \\
MM10 & $37: 41.2530$ & $-119: 05.7668$ & 2635 & Agnew Meadow \\
MM11 & $37: 40.4903$ & $-119: 01.2433$ & 2572 & Crater Flat \\
MM12 & $37: 38.4734$ & $-119: 01.6206$ & 2554 & N Mammoth Mtn \\
MM13 & $37: 38.1832$ & $-119: 03.2691$ & 2810 & Reds Lake \\
MM14 & $37: 37.6045$ & $-119: 01.8953$ & 3381 & Mammoth Summit \\
MM15 & $37: 34: 03$ & $-119: 05: 05$ & 2060 & Cold Creek \\
MM17 & $37: 35: 34$ & $-119: 03: 25$ & 2677 & Red Cones \\
MM18 & $37: 36.7252$ & $-119: 01.3462$ & 2632 & Horseshoe Lake \\
MM19 & $37: 36: 56$ & $-119: 02: 27$ & 2890 & Boundary Creek \\
MM20 & $37: 35.2857$ & $-118: 54.6615$ & 2647 & Laurel Canyon \\
MM21 & $37: 34.2692$ & $-118: 47.2164$ & 2214 & McGee Moraine \\
MM22 & $37: 41.1754$ & $-118: 59.2696$ & 2904 & Dry Creek \\
MM23 & $37: 26.2999$ & $-118: 44.7207$ & 3211 & Upper Rock Creek \\
MM24 & $37: 42.5695$ & $-119: 02.4973$ & 2594 & Deadman Creek \\
\hline & & & &
\end{tabular}




\section{Problems}

We suffered relatively few breakdowns and recorded $\sim 87 \%$ of our targeted data. The most serious causes of data loss are given in Table 8.

\section{Table 8 - Causes of Lost Data}

A "STRT OFF" is an unexpected cessation of recording before the disk is full, and is often caused by a SCSI failure. We minimised data loss from this cause by monitoring closely the performance of each DAS and disk.

\begin{tabular}{lc}
\hline \multicolumn{1}{c}{ Cause } & \% data lost \\
\hline & \\
Batteries discharging & 3 \\
Failure to receive the OMEGA time signal & 3 \\
STRT OFFs \& SCSI driver errors & 2 \\
DAS breakdown & 2 \\
Sensor malfunctions & 2 \\
GPS clock malfunctions & 1 \\
\hline
\end{tabular}

Other, minor, problems included:

1. The sensor-DAS cables tend to be so short that the DAS and disk could not be placed sufficiently far away from the sensor. The sensor then records a burst of noise when the disk is spun up to receive a RAM dump of data.

2. Some DASes produced low-amplitude (up to a few tens of counts) noise spikes at 1-s intervals on one or more channels. These corrupted the seismic signals to varying degrees and could cause tens of thousands of triggers.

3. The DAS connectors are extremely stiff and since not all of the fieldworkers were endowed with Schwartzenegger-like fists, occasionally a cable would be improperly connected.

4. Some wires were chewed and shorted out by animals.

5. Despite the fact that we deployed in the height of the summer tourist season, and some of the stations were not very well concealed, the only possible vandalism suffered was that a solar panel wire was cut at Grant Lake.

\section{Seismic activity in the area during the project}

After a fairly quiet Spring, the level of seismic activity in the Mammoth Lakes area greatly increased at the beginning of July 1997, at the time when installation of our network was completed. A series of vigorous swarms occurred in the eastern part of our network, with shocks up to $\mathrm{M}_{\mathrm{L}}=3.5$ and up to 250 earthquakes located per day by the permanent NCSN network. This activity was accompanied by accelerated inflation of the resurgent dome (Figure 3).

Since our temporary network is much denser than the NCSN network in the epicentral area, 
and is comprised of three-component stations in contrast to the single-component typically deployed at NCSN stations, several times as many earthquakes will be locatable using our data. This will clearly provide an excellent dataset for the studies planned that require a substantial volume of local earthquake recordings.

About 100 LP events beneath Devil's Postpile were visually identified from the NCSN data whilst our network was operational (Figure 4). These were all recorded on several of our threecomponent stations and provide sufficient data for source mechanism studies of this class of events.

\section{Outreach}

Our project, coupled with fact that there was an unusually high level of seismicity in the area, and accelerated inflation of the resurgent dome, engendered considerable interest among the local residents and the local and state press. Newspaper articles were published by the Mammoth Times, the Review Herald (Mammoth Lakes and Mono County) and the Los Angeles Times that mentioned this project. In addition, we demonstrated a seismic station to a field party from the Sutter Buttes Volcano Observatory and held an Open House for local residents. This latter function was attended by about 15 local residents, to whom we demonstrated the servicing of a seismic station and showed earthquake recordings.

\section{Acknowledgments:}

Most of the equipment was provided by the NERC (U. K.) Geophysical Equipment Pool, loan \# 540. We thank Prof. Paul Davis of UCLA for lending us a DAS on short notice. We are grateful

to the U. S. Forest Service and the National Park Service for cooperation and help in siting and deploying our stations.

\section{References}

Julian, B. R., A. M. Pitt and G. R. Foulger, 1998, Seismic image of a $\mathrm{CO}_{2}$ reservoir beneath a seismically active Volcano, Geophys. J. Int., 133, F7-F10. 


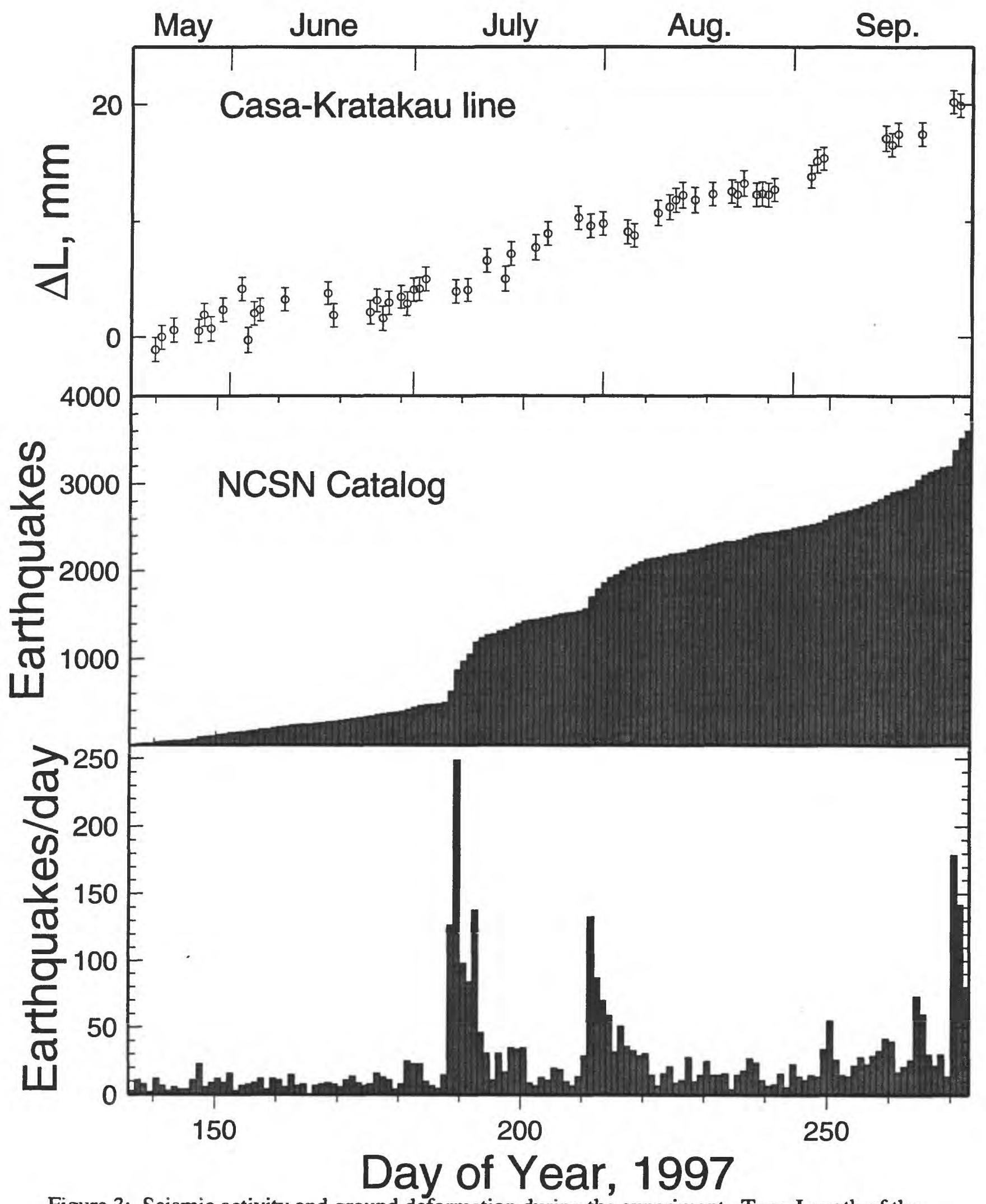

Figure 3: Seismic activity and ground deformation during the experiment. Top: Length of the geodimeter line CASA-KRAKATAU, which crosses the resurgent dome (J. Langbein, personal communication, 1997); middle: cumulative number of earthquakes in the catalog of the Northern California Seismic Network (NCSN); bottom: number of earthquakes per day. 


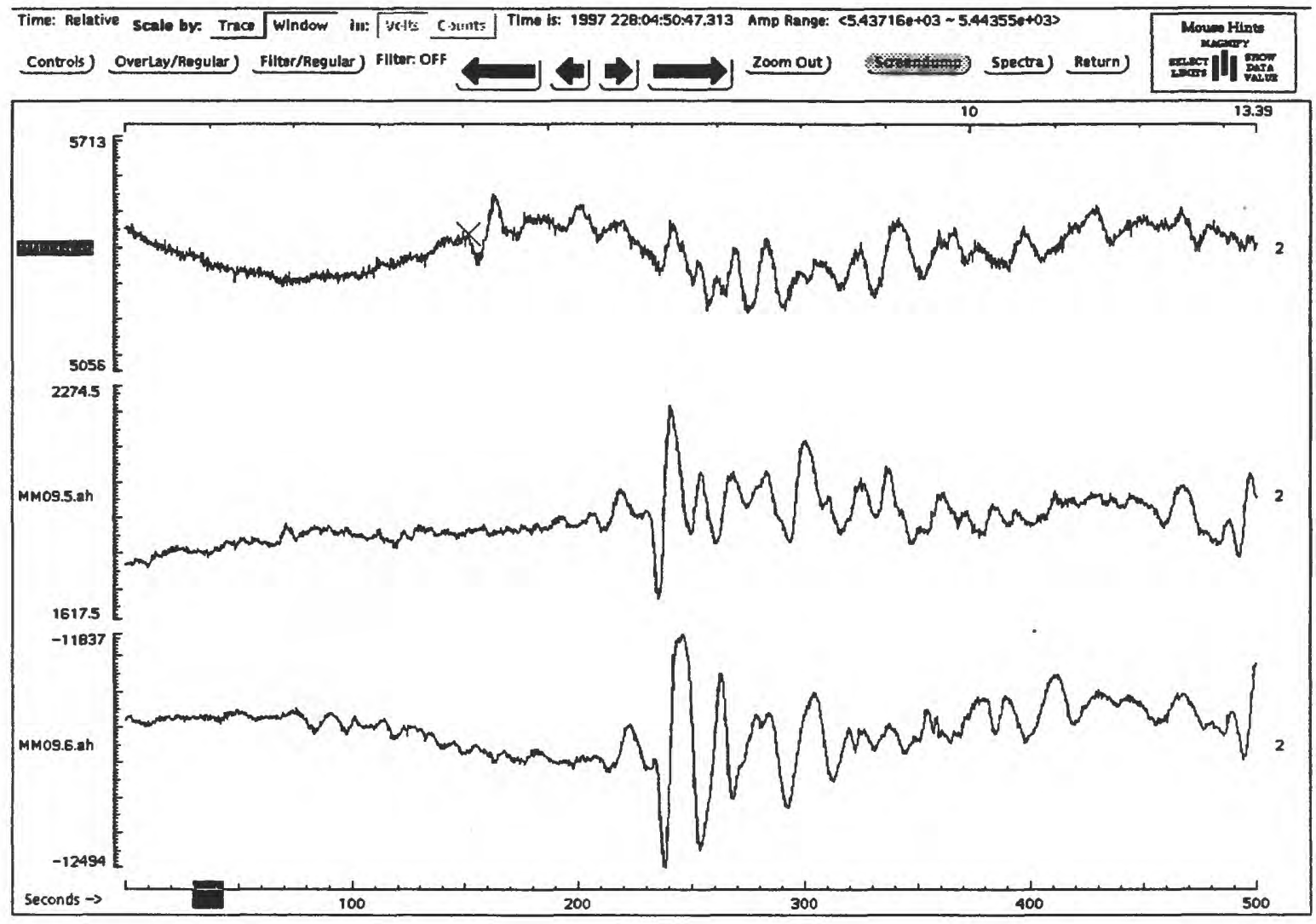

Figure 4: Example of a long-period earthquake recorded at station MM09 (King Creek). 
APPENDIX 1: STATION DESCRIPTIONS 


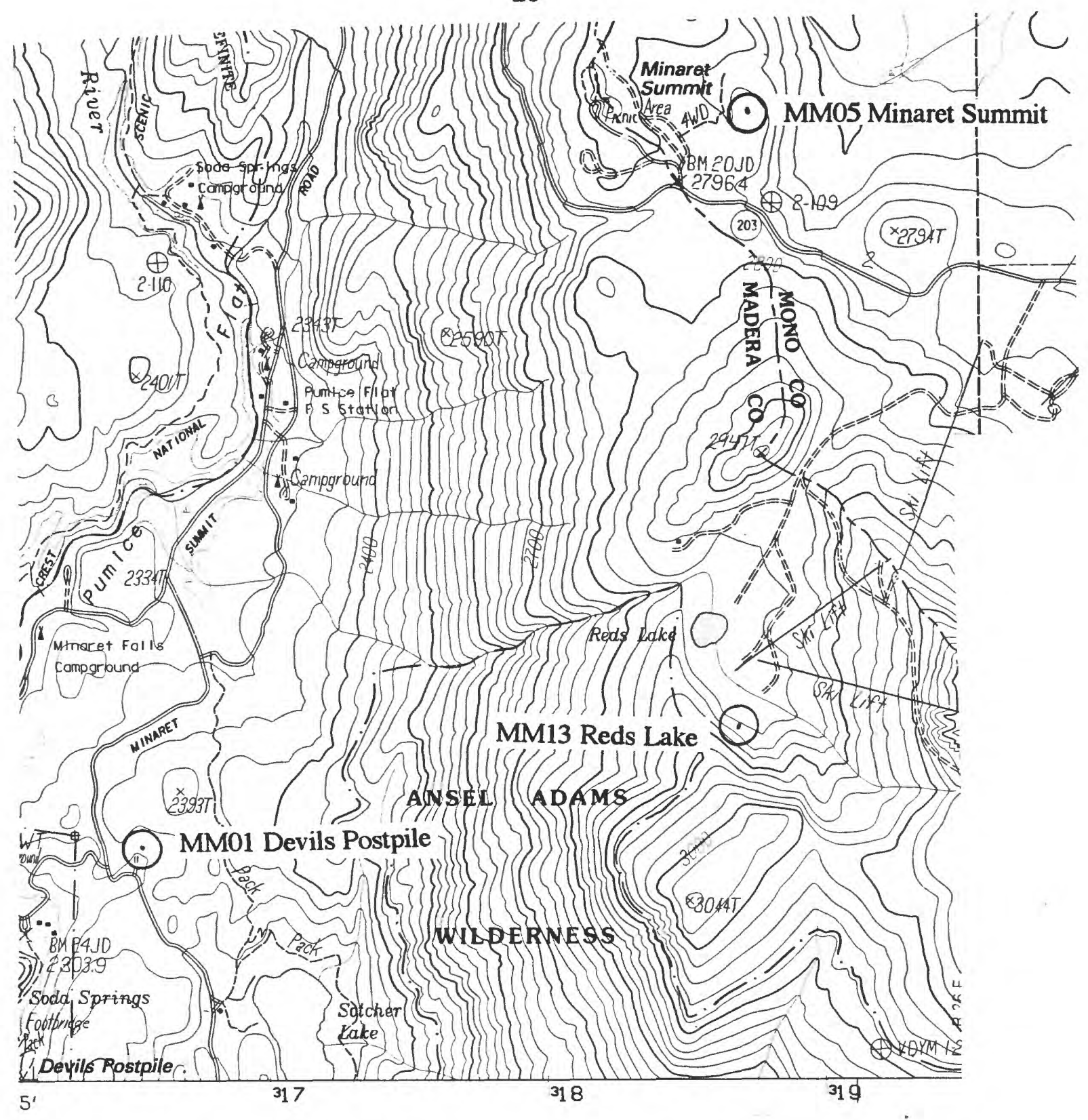

MM01 Devil's Postpile: From turnoff into Devil's Postpile National Monument, go south $0.15 \mathrm{~km}(0.09 \mathrm{mi})$ on SR 203 and turn left (east) onto dirt trail. Station was in USGS dilatometer shed (key required) about 100 meters ahead. Trail was poor in 1997 and we usually walked from the highway. (Photo 1.1) [Mammoth Mtn. 7.5' quad., 1992].

MM05 Minaret Summit: From Mammoth Mountain lodge, go west $2.1 \mathrm{~km}(1.3 \mathrm{mi})$ on SR 203 and turn right (north) into Minaret Summit viewpoint/picnic area. Bear right on dirt roads $0.18 \mathrm{~km}(0.11 \mathrm{mi})$ to USFS barrier at start of bike trail to the NE (4WD on map). Walk 135 meters along this trail until it curves to the left and down. A few meters past this bend, leave the trail and walk 70 meters up the hill to the right (east). The station was on the top of this low hill. (Photos 5.1, 5.2) [Mammoth Mtn. 7.5' quad., 1992].

MM13 Red's Lake: From Mammoth Mountain lodge, go west $0.5 \mathrm{~km}(0.31 \mathrm{mi})$ on SR 203, turn left (south) onto dirt road, and drive SW $1.5 \mathrm{~km}(0.93 \mathrm{mi})$ toward Red's Lake. Turn left (south), drive under ski lifts, and go $0.75 \mathrm{~km}(0.47 \mathrm{mi})$ to the end of the road on the sandy flat below the hillside SSE of Red's Lake. Station was near foot of hillside (Photos 13.1, 13.2). [Mammoth Mtn. 7.5' quad., 1992]. 


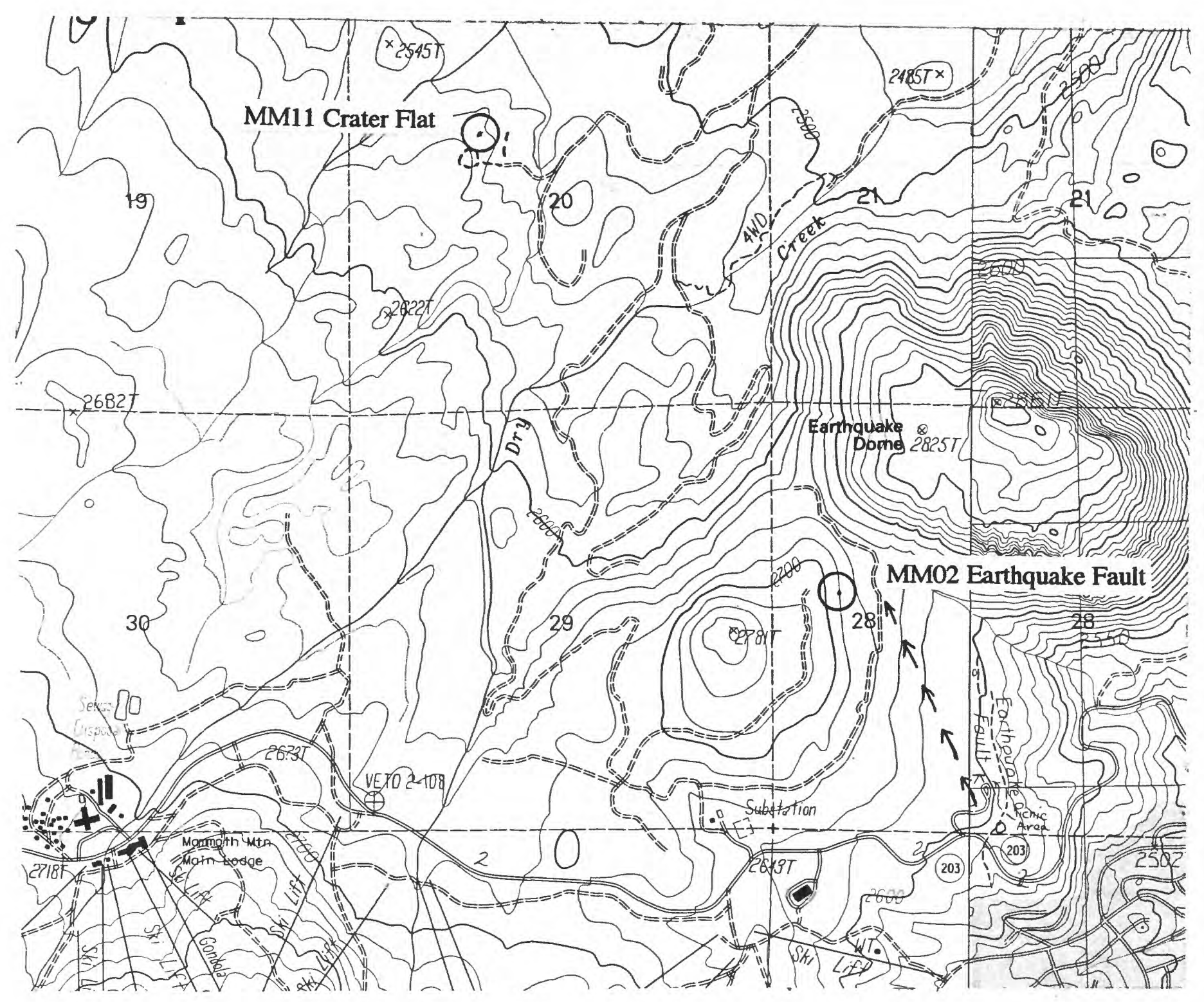

MM02 Earthquake Fault: From junction with Lake Mary Rd. in Mammoth Lakes, go west on SR 203 for $2.9 \mathrm{~km}$ (1.8 mi) and turn right (north) into Earthquake Fault picnic area. After $0.06 \mathrm{~km}$ ( $0.04 \mathrm{mi})$ turn left (north) onto 4WD trail (not on USGS map - see arrows on map above) and drive $1.0 \mathrm{~km}(0.60 \mathrm{mi})$ to a large boulder on the right. The station was on a rhyolite outcrop about 50 meters to the left (SW). (Photos 2.1, 2.2, 2.3) [Mammoth Mtn. 7.5' quad., 1992].

MM11 Crater Flat: From junction with Lake Mary Rd. in Mammoth Lakes, go west on SR 203 for $1.4 \mathrm{~km}(0.9 \mathrm{mi})$ and turn right (north) onto the "Scenic Route" (not on map). After $4.4 \mathrm{~km}$ $(2.75 \mathrm{mi})$, turn left (WNW) on road signposted toward Inyo Craters. Go $1.21 \mathrm{~km}(0.75 \mathrm{mi})$ and turn left (west) on Upper Dry Creek Rd. After another $0.76 \mathrm{~km}(0.47 \mathrm{mi})$ take indistinct right fork onto Forest Road 3S30 (marked by small sign at ground level 15 meters beyond fork). After a further $1.14 \mathrm{~km}(0.71 \mathrm{mi})$ bear right at fork. Go $0.34 \mathrm{~km}(0.21 \mathrm{mi})$ further and bear left at fork. The road ends at a turnaround loop. The station was about 90 meters north of the loop on a small basalt outcrop. (Photos 11.1, 11.2) [Mammoth Mtn. 7.5' quad., 1992]. 


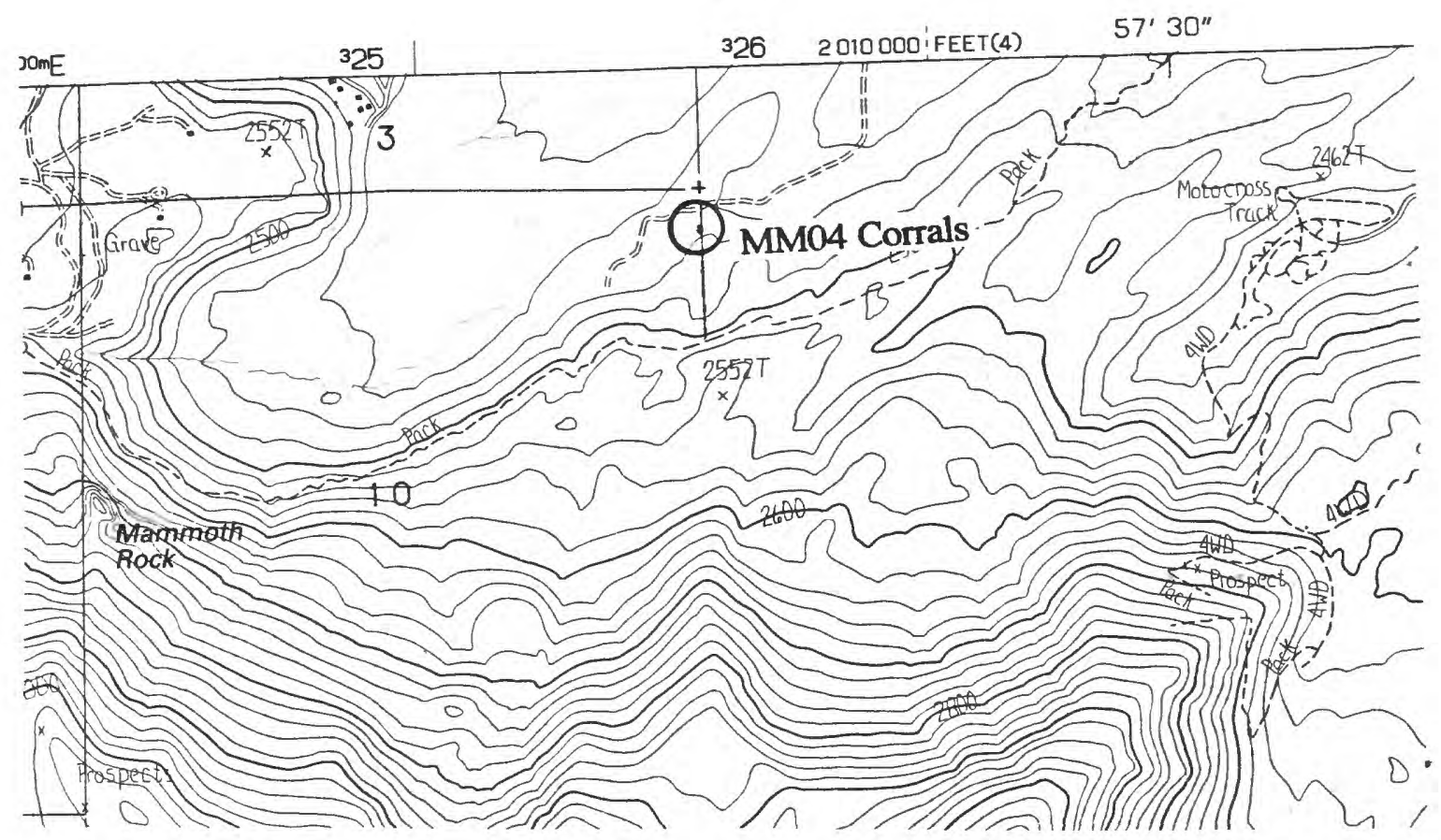

MM04 Corrals: From intersection of Old Mammoth Rd., go SSE $0.43 \mathrm{~km}(0.27 \mathrm{mi})$ on Sherwin Creek Rd. to the USFS and corrals. Turn right through gate onto dirt road, drive south $0.24 \mathrm{~km}(0.15 \mathrm{mi})$, fork right and continue south and then west $1.34 \mathrm{~km}(0.83 \mathrm{mi})$ to a wire section-line fence with wooden gate posts on left. The station was about 15 meters left (south) of the road along the wire fence (Photo 4.1). [Bloody Mtn. 7.5' quad., 1990].

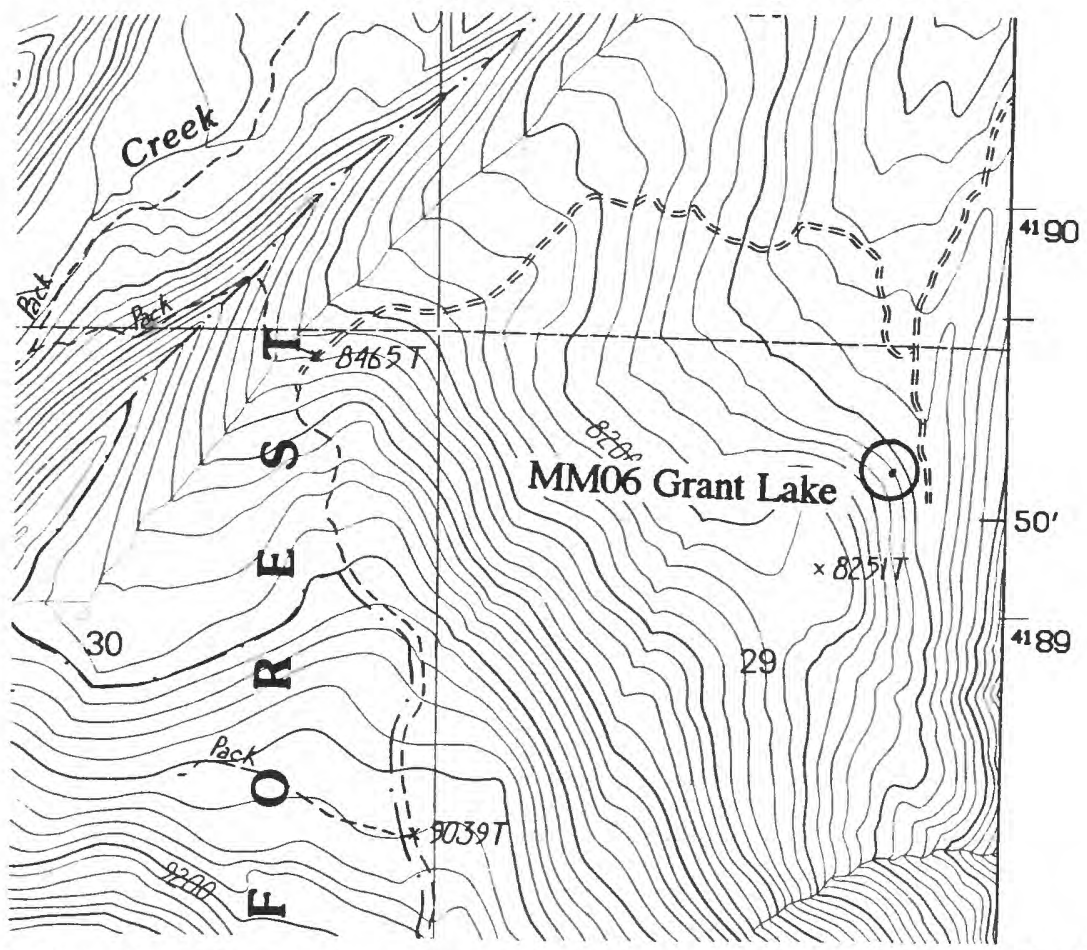

MM06 Grant Lake: From its northern junction with US 395, go $2.40 \mathrm{~km}$ (1.49 mi) SW on SR 158 (June Lake Loop) and turn right onto road signposted to Walker and Parker Lakes. After another $2.16 \mathrm{~km}(1.34 \mathrm{mi})$, turn left onto a dirt road and go $3.00 \mathrm{~km}(1.86 \mathrm{mi})$ to a fork at a sign about fire safety. Turn left and go $0.16 \mathrm{~km}(0.10 \mathrm{mi})$ until a grove of trees on the right meets the road. The station was about 100 meters west of the road, through the grove at the base of a granite outcrop. NCSN/UNR station SLKR is on top of the outcrop at the end of the ridge. (Photos 6.16.3) [Koip Peak 7.5’ quad., 1992]. 


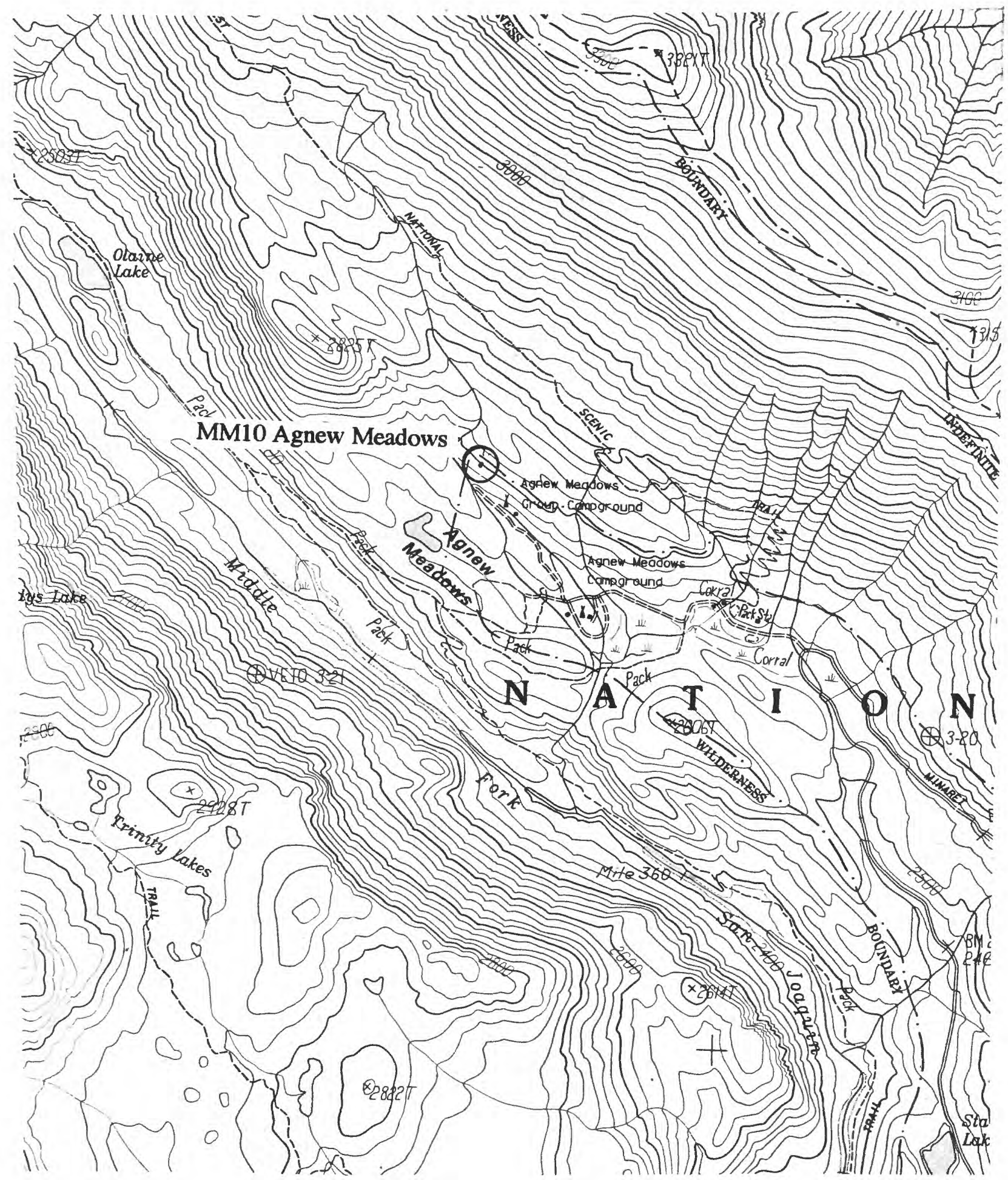

MM10 Agnew Meadows: From SR 203, drive NW into Agnew Meadows and follow "Group Campground" signs for $1.68 \mathrm{~km}$ (1.04 mi) to the very end of the road. Station was on shoulder of granite outcrop north of end of road. (Photos 10.1, 10.2) [Mammoth Mtn. 7.5' quad., 1992]. 


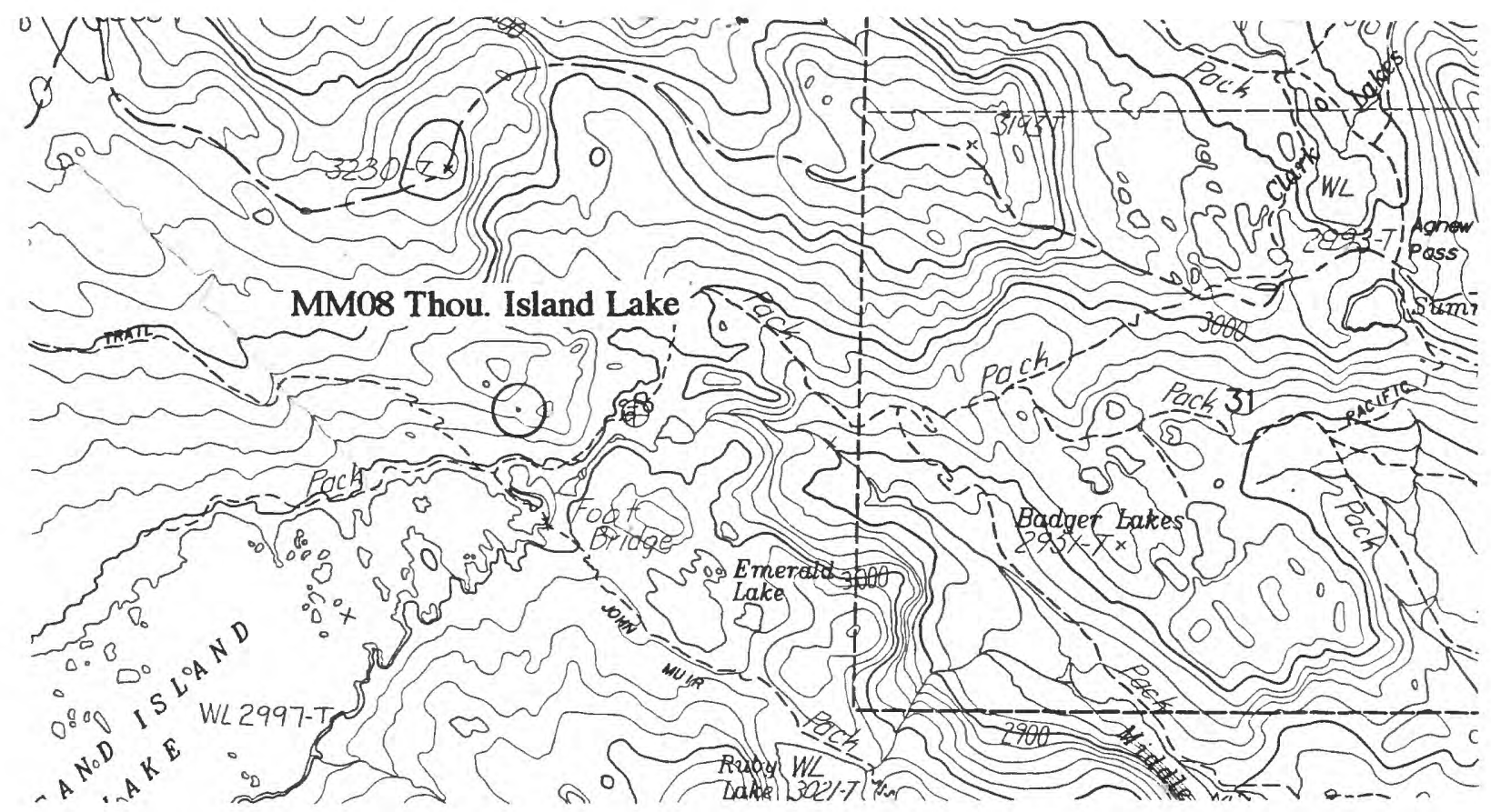

MM08 Thousand Island Lake: From Agnew Meadow pack station, walk NW along the River Trail about $11 \mathrm{~km}(7 \mathrm{mi})$ until a small footbridge across the outflow from Thousand Island Lake comes into view. Ascend the broad rocky gully to the right (NNW), gaining about 50 meters of elevation, cross a saddle and descend a few meters to the station site (Photos 8.1-8.3) [Mt. Ritter 7.5' quad., 1992].

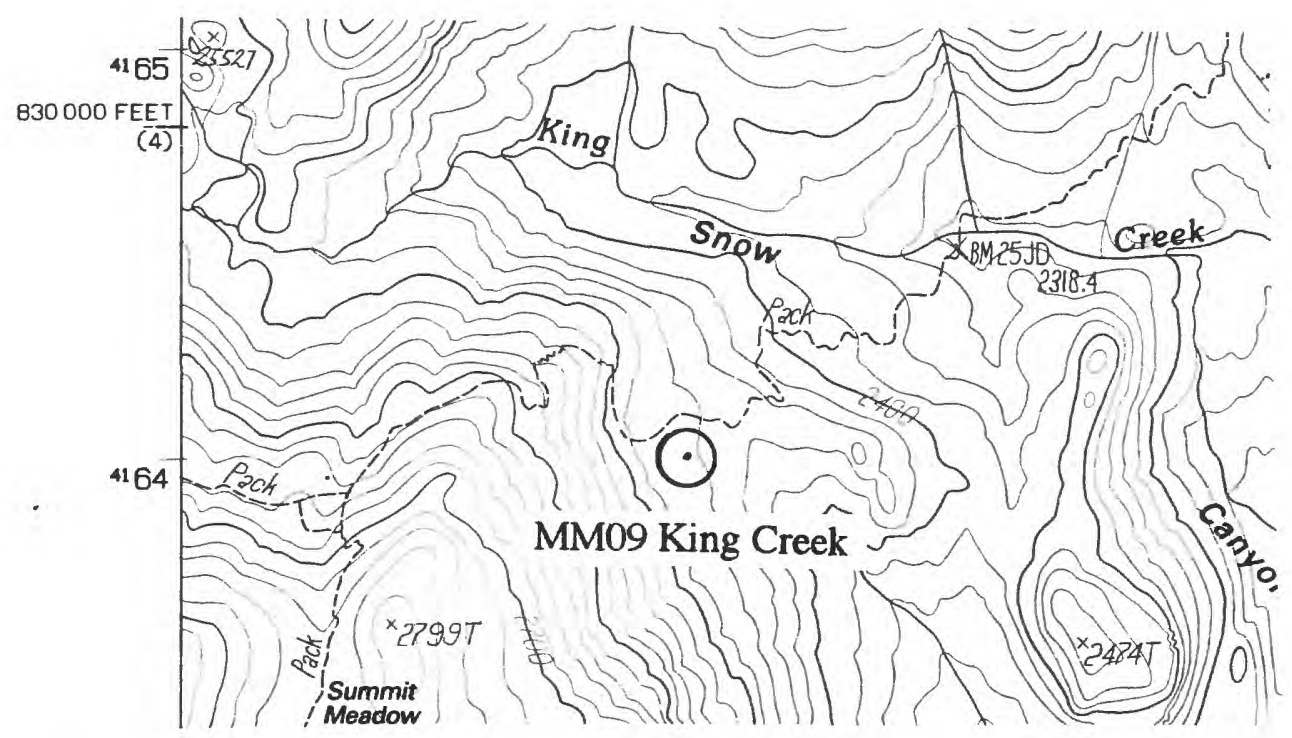

MM09 King Creek: The bridge across the Middle Fork of the San Joaquin River near the Devil's Postpile parking lot was out in 1997. The following route uses a bridge $0.9 \mathrm{mi}$ to the south: From the Rainbow Falls trailhead at Red's Meadow, go south $0.3 \mathrm{~km}$ to trail junction, turn right (west) and go $0.7 \mathrm{~km}(0.4 \mathrm{mi})$ to bridge. Cross river and continue west and then north 1.8 $\mathrm{km}(1.1 \mathrm{mi})$ to a fork signposted to King Creek and Devil's Postpile. From here on, the two routes are the same. Take the left (King Creek) fork SW for $2.4 \mathrm{~km}$ (1.5 mi). Wade across King Creek and follow the trail SW for $1.5 \mathrm{~km}(0.9 \mathrm{mi})$. Near the station, the trail climbs steeply, curves left (south) onto a shoulder, then right (west then north) around an outcrop. The station was on the outcrop, within the loop of the trail (Photo 9.2). Note: The map is wrong; the trail passes south, not north, of the station. (Photos 9.1. 9.2) [Crystal Crag 7.5' quad., 1984]. 


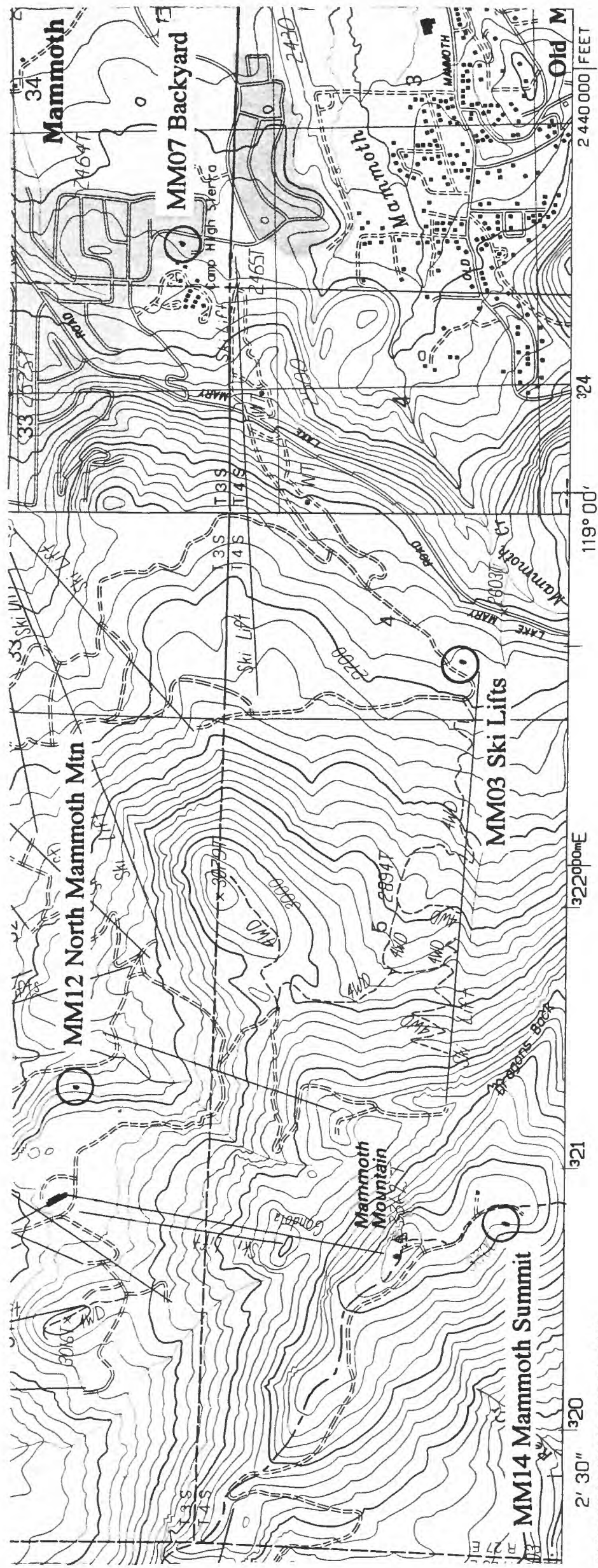

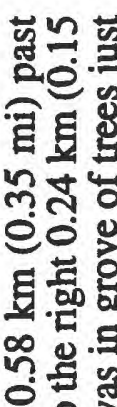

. 3

귱ำ

보붕

ஸู่芯

焉

g용.

nov

ले

는훈온혼

\% 등

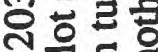

$\propto 00 \%$

ง.․ㅡㄹ

든ํํㄹㄹㅗ

萌

ఖํํำ

สิ

- \&

मे ปู

둰융

త.

踏

ช $\mathrm{0}=$

西此

령요요

తี त्न

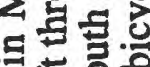

흉유

조은

롤

矛喝

$\sum$ 홀

ข้ำ

구으.

렁

독.을 은

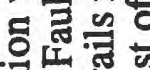

인

竘造

두ㅇㅝㅝ

은을

圷出융

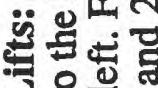

월

ชี

๓

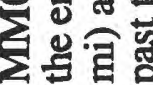

$\because 70$

융

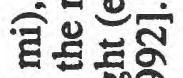

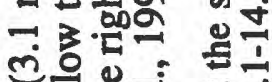

드용

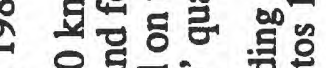

오 들

n

ᄂ.

m:

스류

뜽:=

ㄷㅇ용

원

荡品

켜ํㅇำ

E

웅

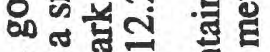

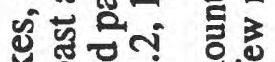

ปั

- బ寻官

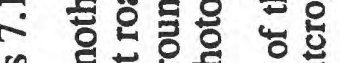

을.녕혈 응

帘 $E$ a

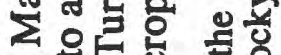

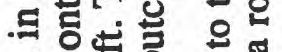

ग

电可

들ํํㄹ

焉寻要

ฮึ่

สำ

월

돌

ธี

열률ㄹㄹㄹ

巧 3

르를

현 跑造

敋递

로용

폻

쳑올을

응ㅎㅍ흥

递

흉 ్ㅕㄴ눈

톨돈

링

运菏

졸

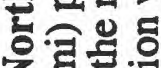

뚱

웅

옹

응

o

द्य

งీ-

으 흥

巨ี

$\Sigma 8$

융

틀

토용

$\sum 5$

บ

토유

음음

语

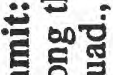

중을

जs in

독ำ

흥요

태ㄹㅠㅠㄹ

乙

Nํํํ웛

究。융

$\sum$ 㱐

$\pm$

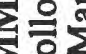




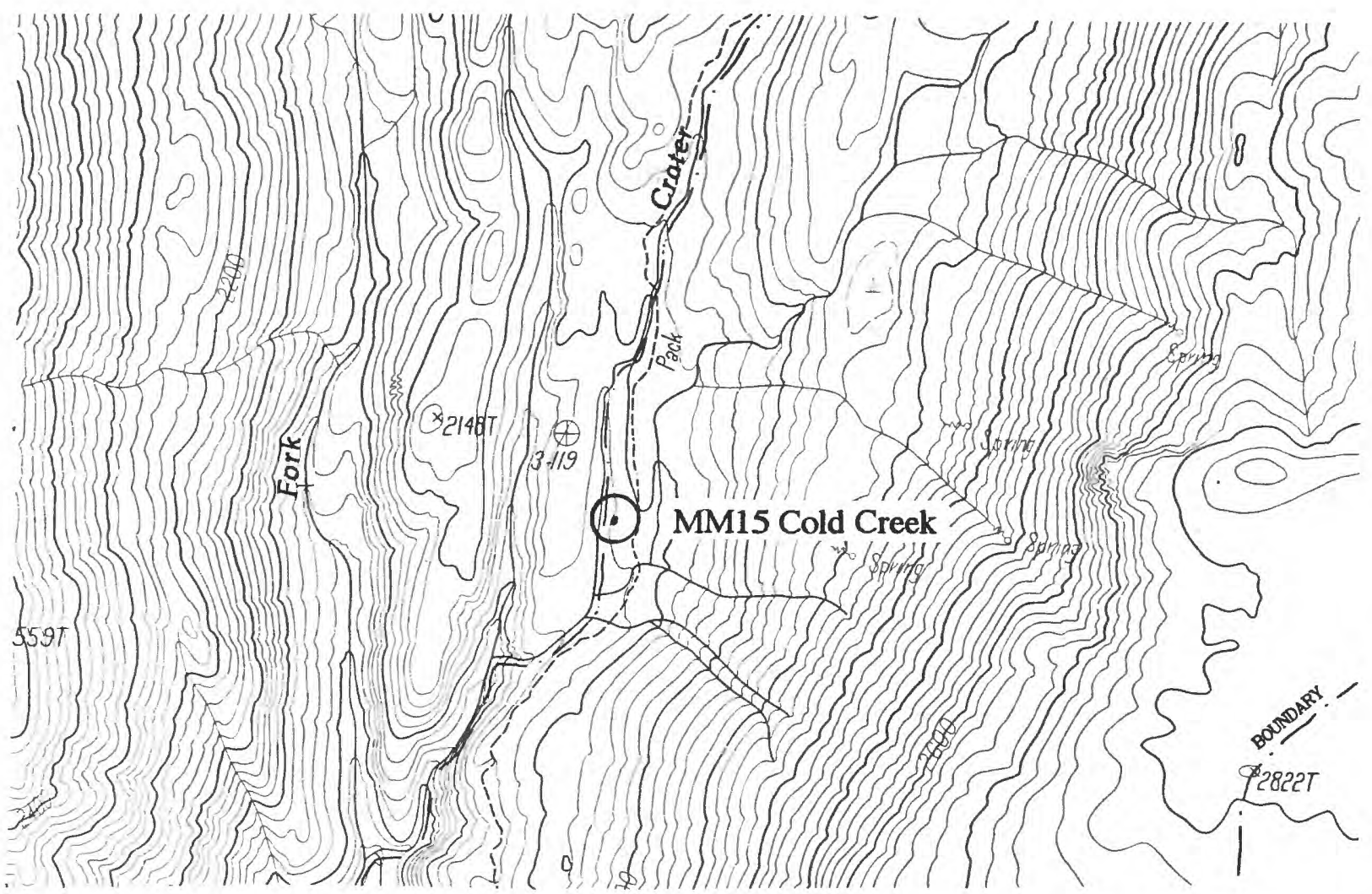

MM15 Cold Creek: From the Rainbow Falls trailhead parking lot at Red's Meadow, hike south $5.8 \mathrm{~km}(3.6 \mathrm{mi})$, following signs for Fish Creek. The station was $0.63 \mathrm{~km}(0.39 \mathrm{mi})$ south of the crossing of Cold Creek and about 60 meters west of a large fallen tree by the trail. (Photos 15.1, 15.2) [Crystal Crag 7.5' quad., 1984].

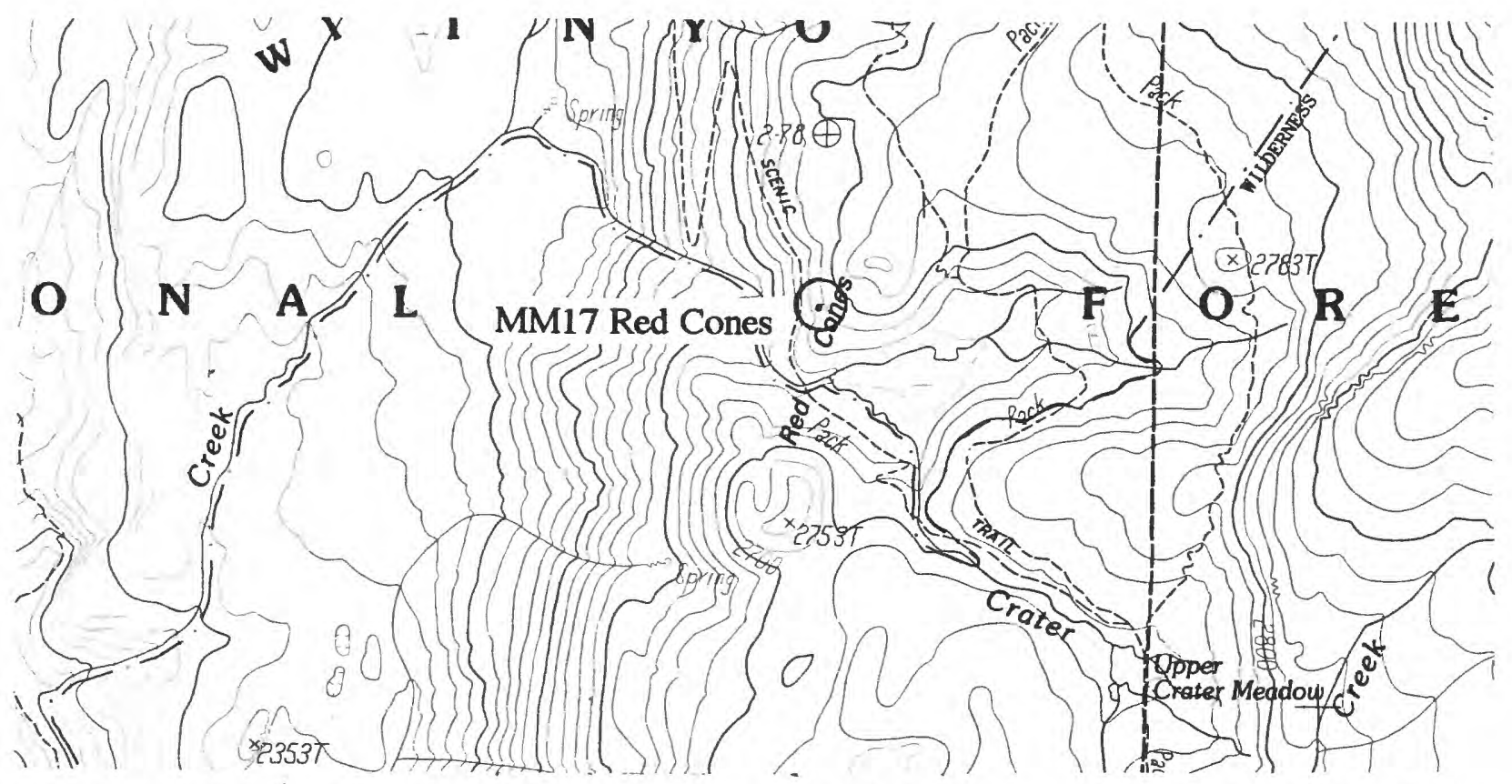

MM17 Red Cones: From the parking lot at Horseshoe Lake, follow signposted trail WSW past McCloud (sometimes McLeod or McLead) Lake, over Mammoth Pass and then SW for a total of $4.1 \mathrm{~km}(2.5 \mathrm{mi})$, following signs for Red Cones, until you see the northern red-capped cinder cone. Turn right off the trail, and cross the north (right) shoulder of the cone and contour left to the station site on the SW side of the cone. (Photos 17.1-17.3) [Crystal Crag 7.5' quad., 1984]. 


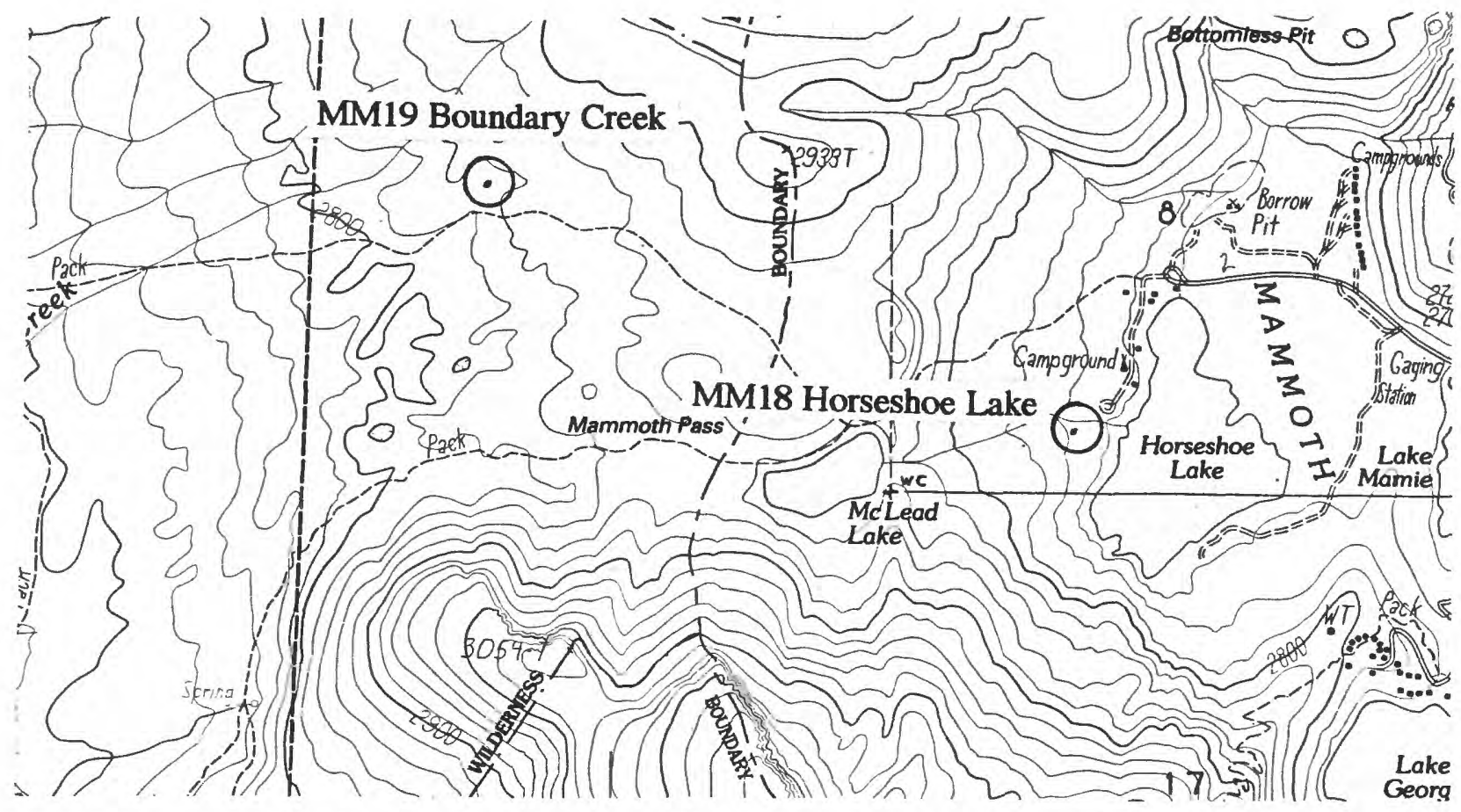

MM18 Horseshoe Lake: Station was in small, broken-down, green-roofed Forest Service cabin in dead trees, about 70 meters SW of public toilets at the Horseshoe Lake parking lot. (Photo 18.1) [Crystal Crag 7.5' quad., 1984].

MM19 Boundary Creek: From parking lot at Horseshoe Lake, follow signposted trail WSW $1.0 \mathrm{~km}(0.6 \mathrm{mi})$ to McCloud (sometimes McLeod or McLead) Lake. As soon as the lake is visible, turn right (NW) onto an indistinct trail uphill. Continue for $1.3 \mathrm{~km}(0.8 \mathrm{mi})$. Station was on basalt outcrop about 70 meters north of the trail (Photos 19.1-19.4) [Crystal Crag 7.5' quad., 1984].

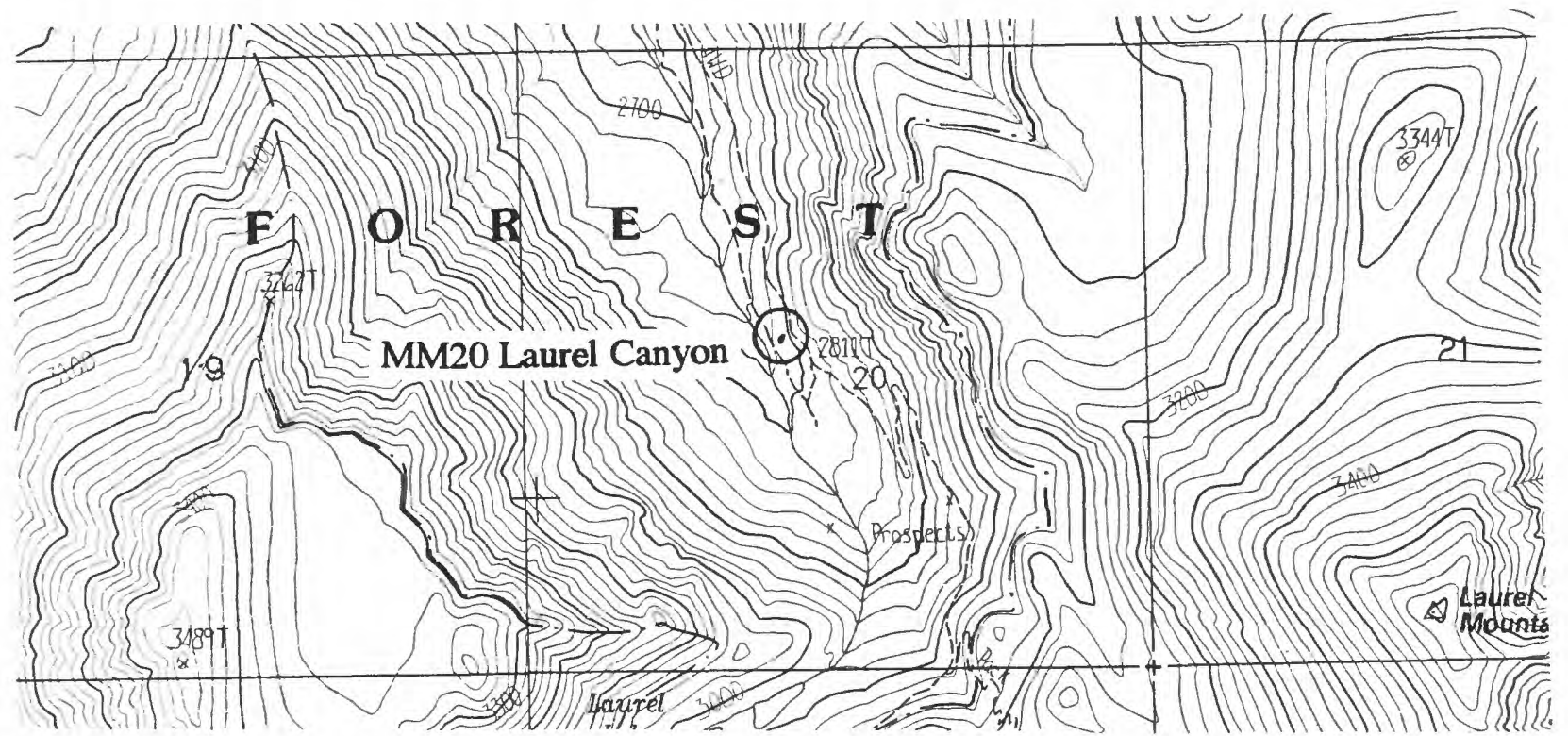

MM20 Laurel Canyon: From Sherwin Creek Road, drive south on rocky 4WD road up Laurel canyon toward Laurel Lakes. The following landmarks should be passed: cattleguard, $0.18 \mathrm{~km}$ (0.11 mi); small brown hut on right, $1.91 \mathrm{~km}(1.19 \mathrm{mi})$; campfire sign on right, $3.12 \mathrm{~km}$ (1.94 $\mathrm{mi})$; cable gate, $3.91 \mathrm{mi}(2.43 \mathrm{mi})$. Cross a red talus slope. The station was at $5.08 \mathrm{~km}(3.16 \mathrm{mi})$, on a black outcrop about 30 meters below the road on the right (west). There is a passing place about 70 metdrs south of the station. (Photos 20.1-20.3) [Bloody Mtn. 7.5' quad., 1990]. 


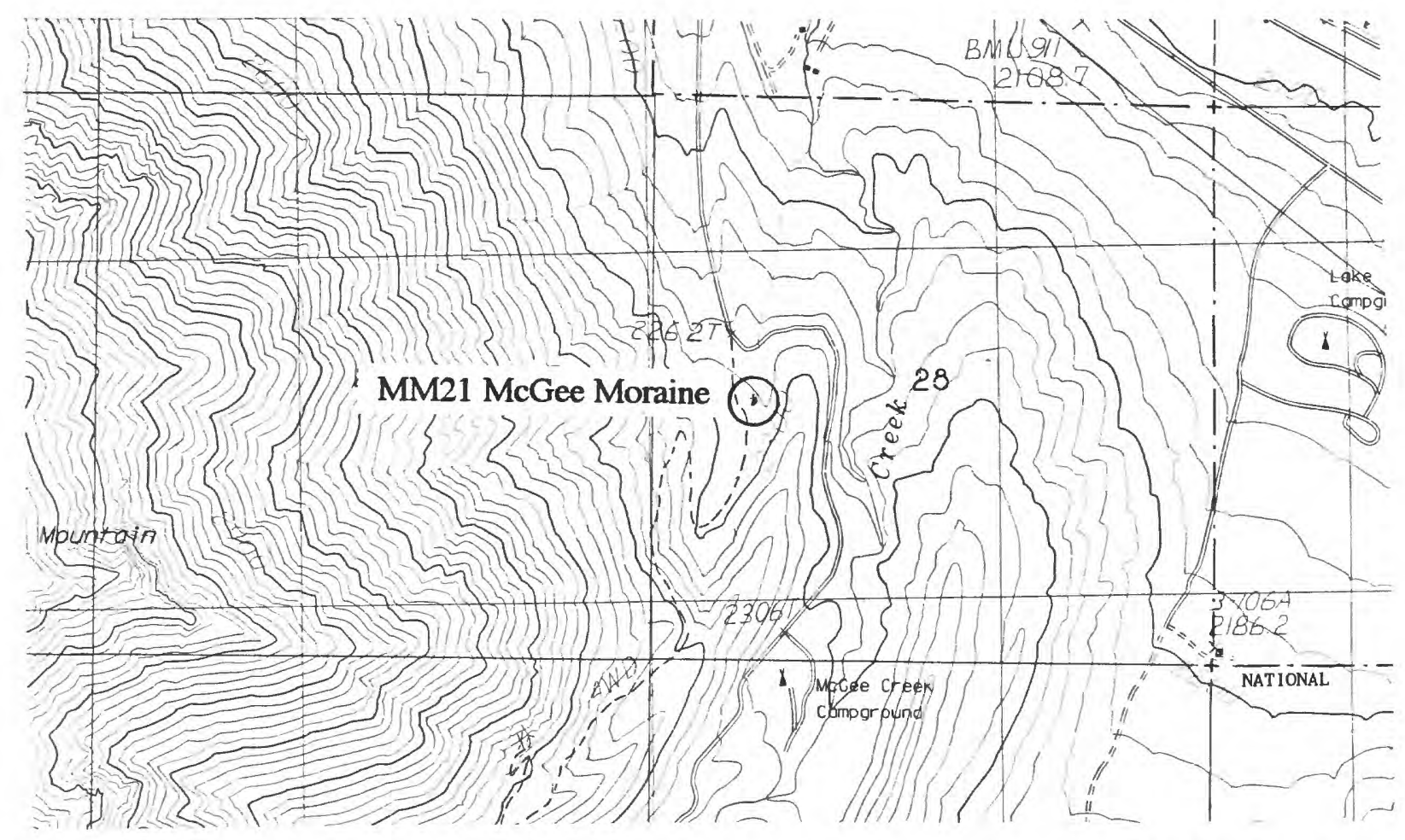

MM21 McGee Moraine: From US 395, drive south on paved road towards McGee Creek campgrounds and pack station. Turn right on a dirt road $1.85 \mathrm{~km}(1.15 \mathrm{mi})$ from US 395 , and continue $0.18 \mathrm{~km}(0.11 \mathrm{mi})$. Station was in sagebrush-covered alluvium about 20 meters left (east) of the road. (Photos 21.1-21.3) [Convict Lake 7.5' quad., 1983].

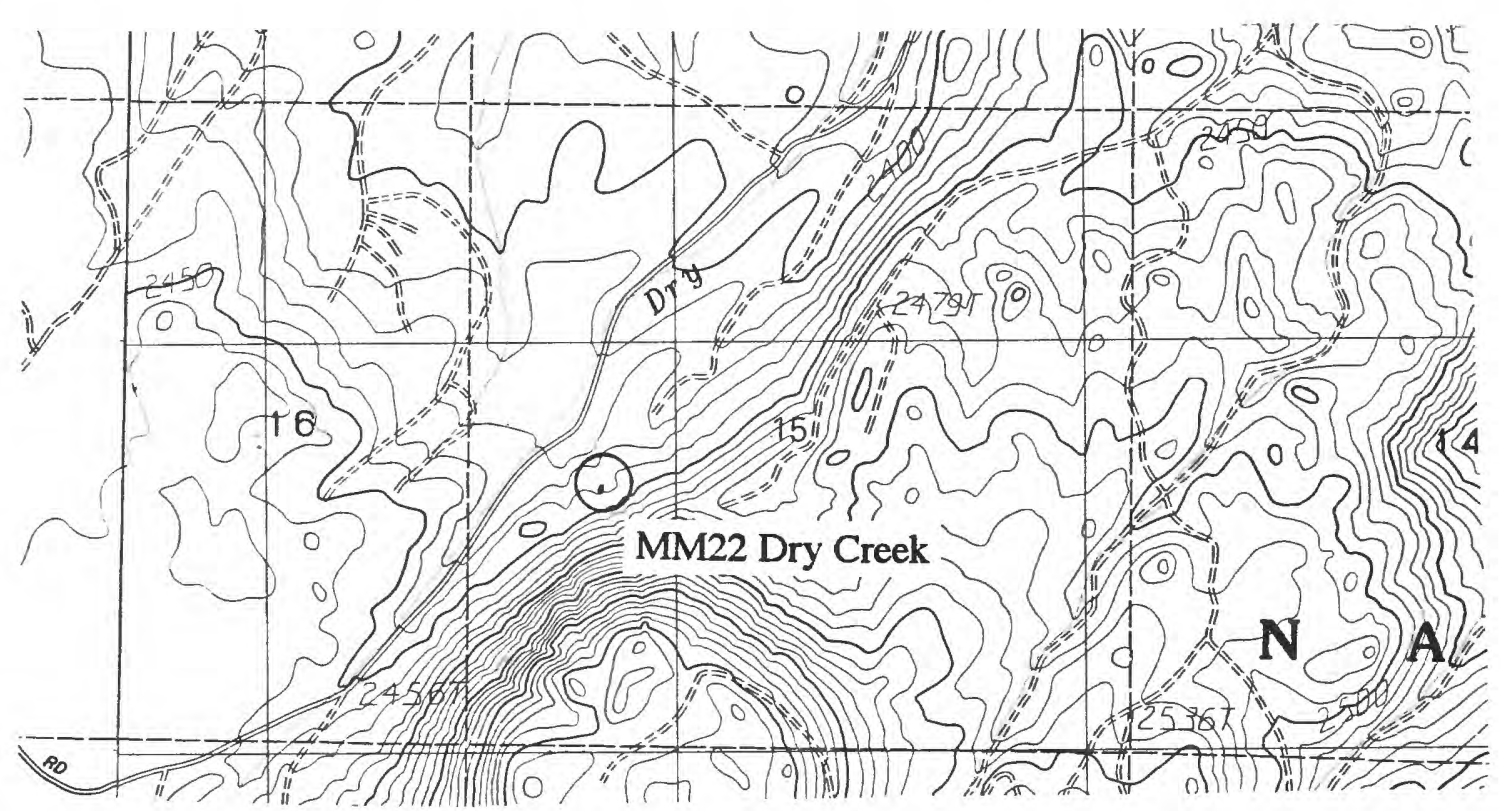

MM22 Dry Creek: From junction with Lake Mary Rd. in Mammoth Lakes, go west on SR 203 for $1.4 \mathrm{~km}(0.9 \mathrm{mi})$ and turn right (north) onto the "Scenic Route" (not on map). Go north 8.00 $\mathrm{km}(4.97 \mathrm{mi})$ and turn right on a dirt road. Go $\mathrm{SW}$ about $1.1 \mathrm{~km}(0.7 \mathrm{mi})$ along this road, go straight (SW) at an indistinct fork (Do NOT go left up steep hill) and continue for $0.16 \mathrm{~km}(0.1 \mathrm{mi})$ to the station location at the end of the road. (Photos 22.1-22.3) [Old Mammoth 7.5' quad., 1983]. 


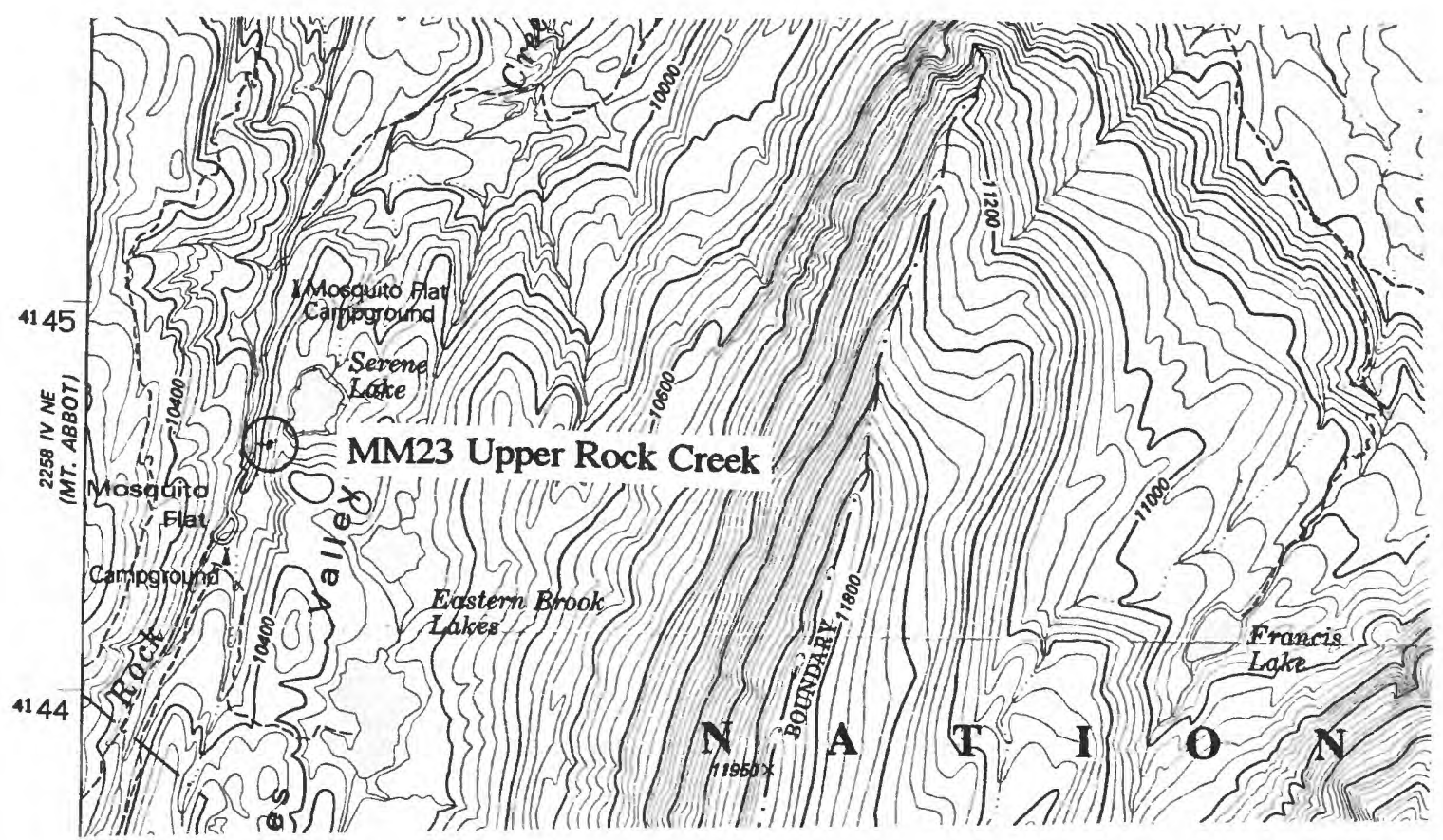

MM23 Upper Rock Creek: From Tom's Place on US 395, drive south about 17 km (10.5 mi) along Upper Rock Creek road to its end. Turn around and drive back $0.24 \mathrm{~km}(0.15 \mathrm{mi})$. Immediately after crossing the creek, park on the right (east). If you put the truck close enough to the bridge you can obscure the "No Parking any time" sign and avoid complaints from citizens. The station is about 30 meters above the road on the east, up a steep slope. (Photos 23.2-23.3)[Mt. Morgan 7.5' quad., 1982].

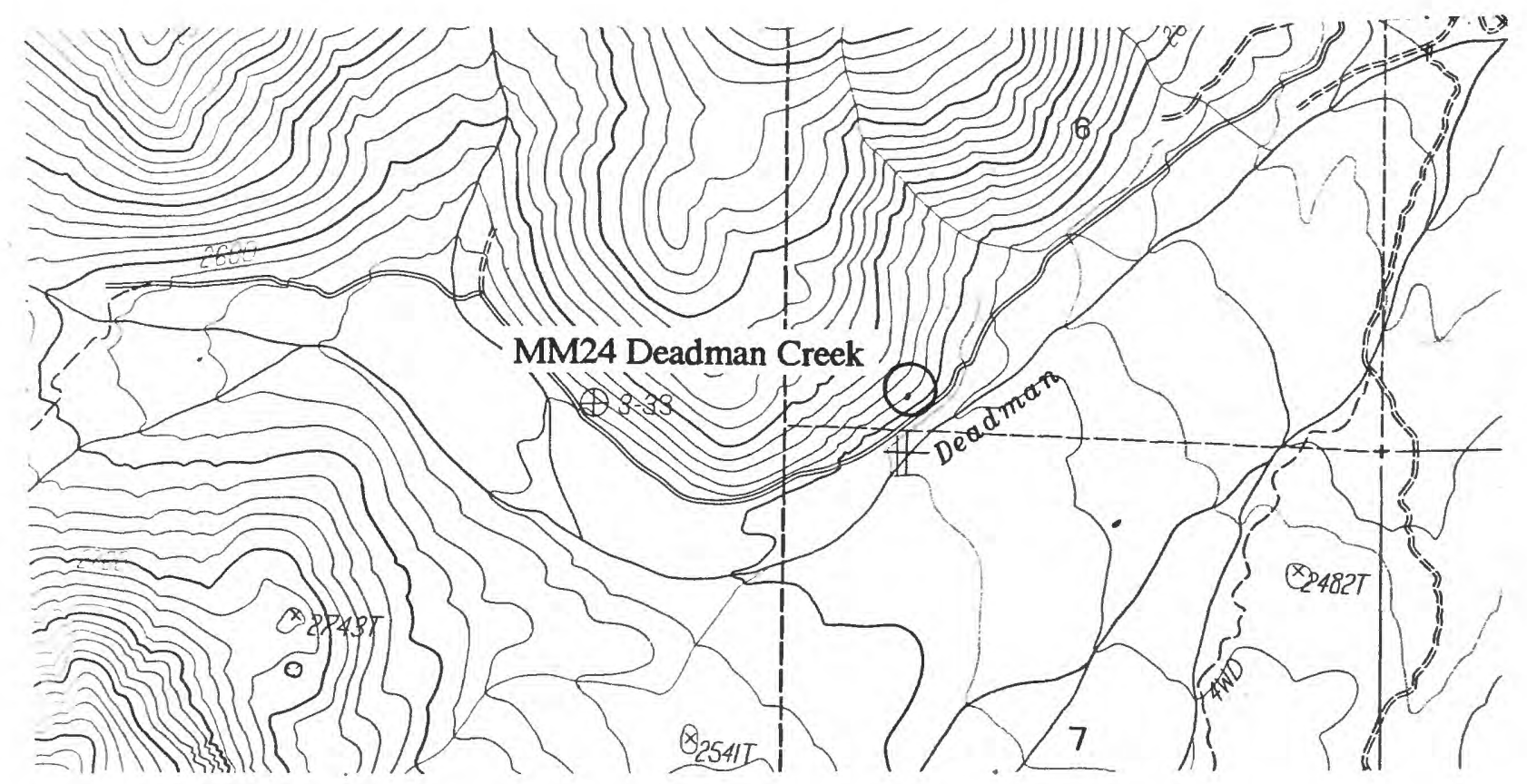

MM24 Deadman Creek: From US 395, drive west on Deadman Creek Rd., continuing straight at the junctions at $4.8 \mathrm{~km}(3.0 \mathrm{mi})$ and $6.1 \mathrm{~km}(3.8 \mathrm{mi})$. The station was $8.0 \mathrm{~km}(5.0 \mathrm{mi})$ from US 395 on an outcrop about 30 meters above the road on the right (NW) side, next to the NCSN station. (Photos 24.1-24.3) [Mammoth Mtn. 7.5' quad., 1992]. 


\section{APPENDIX 2: STATION PIOTOGRAPIIS}

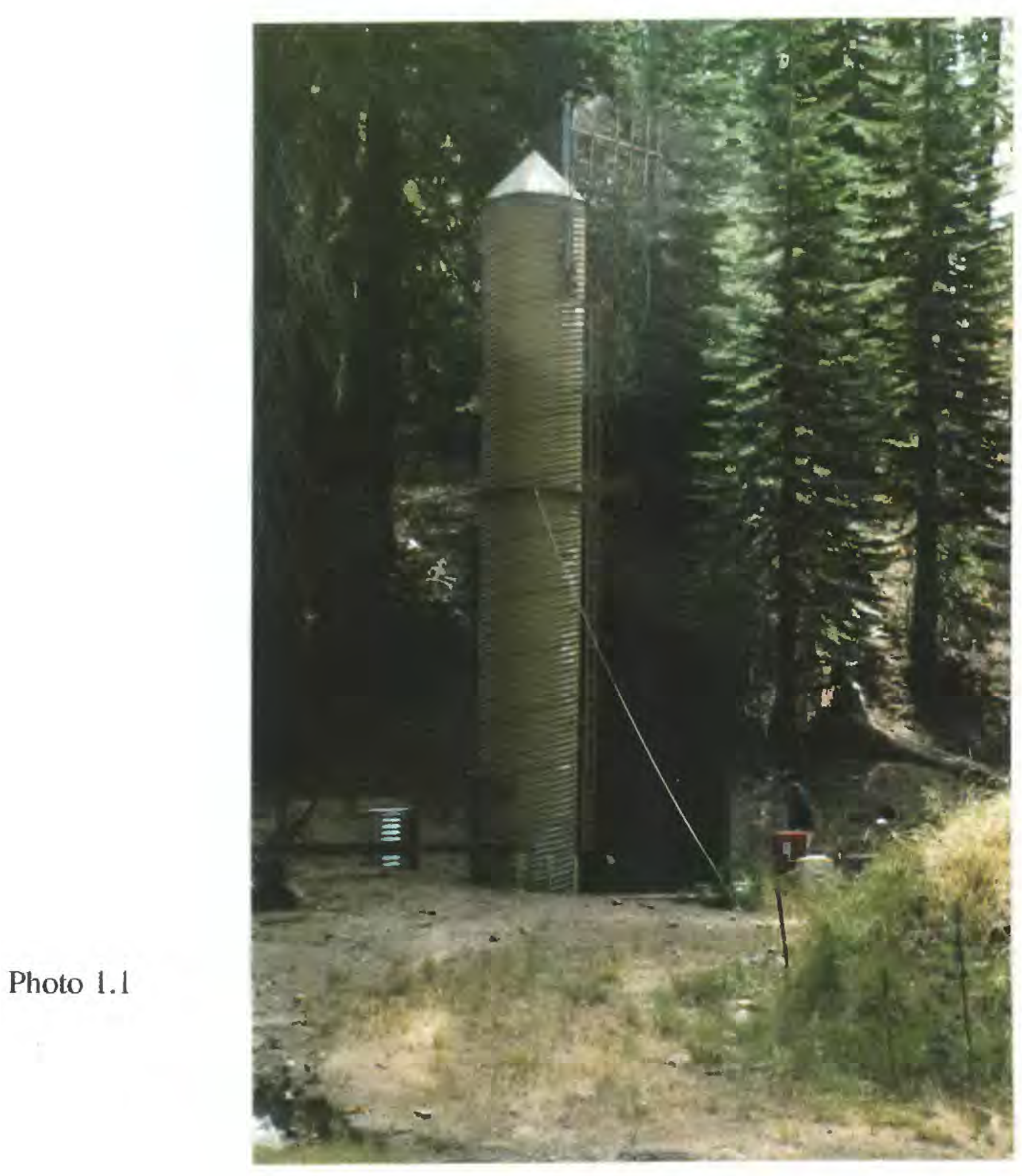

MM01 Devil's Postpile: Station was installed in USGS dilatometer shed (Photo 1.1). Key is required for access. 


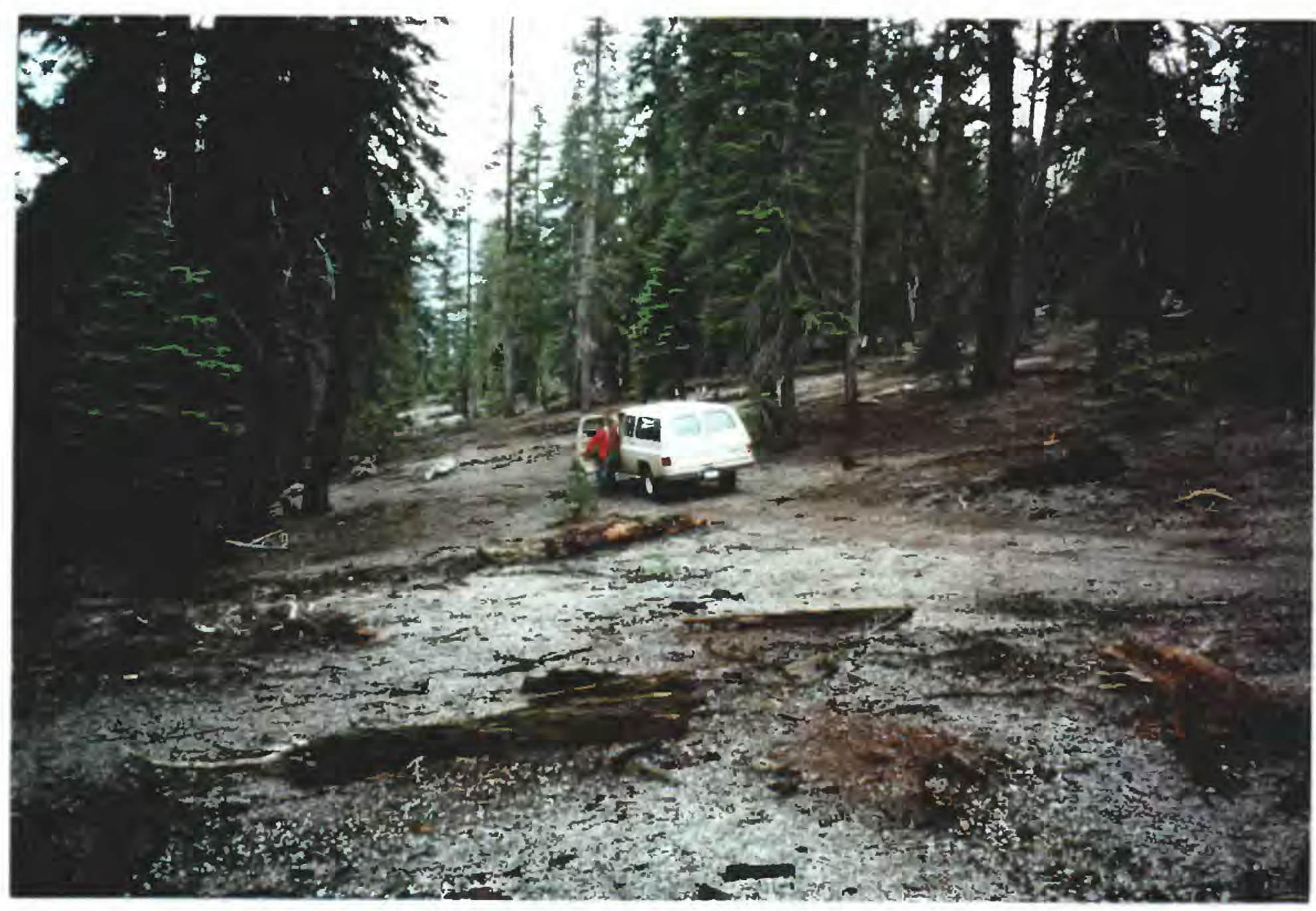

Photo 2.1

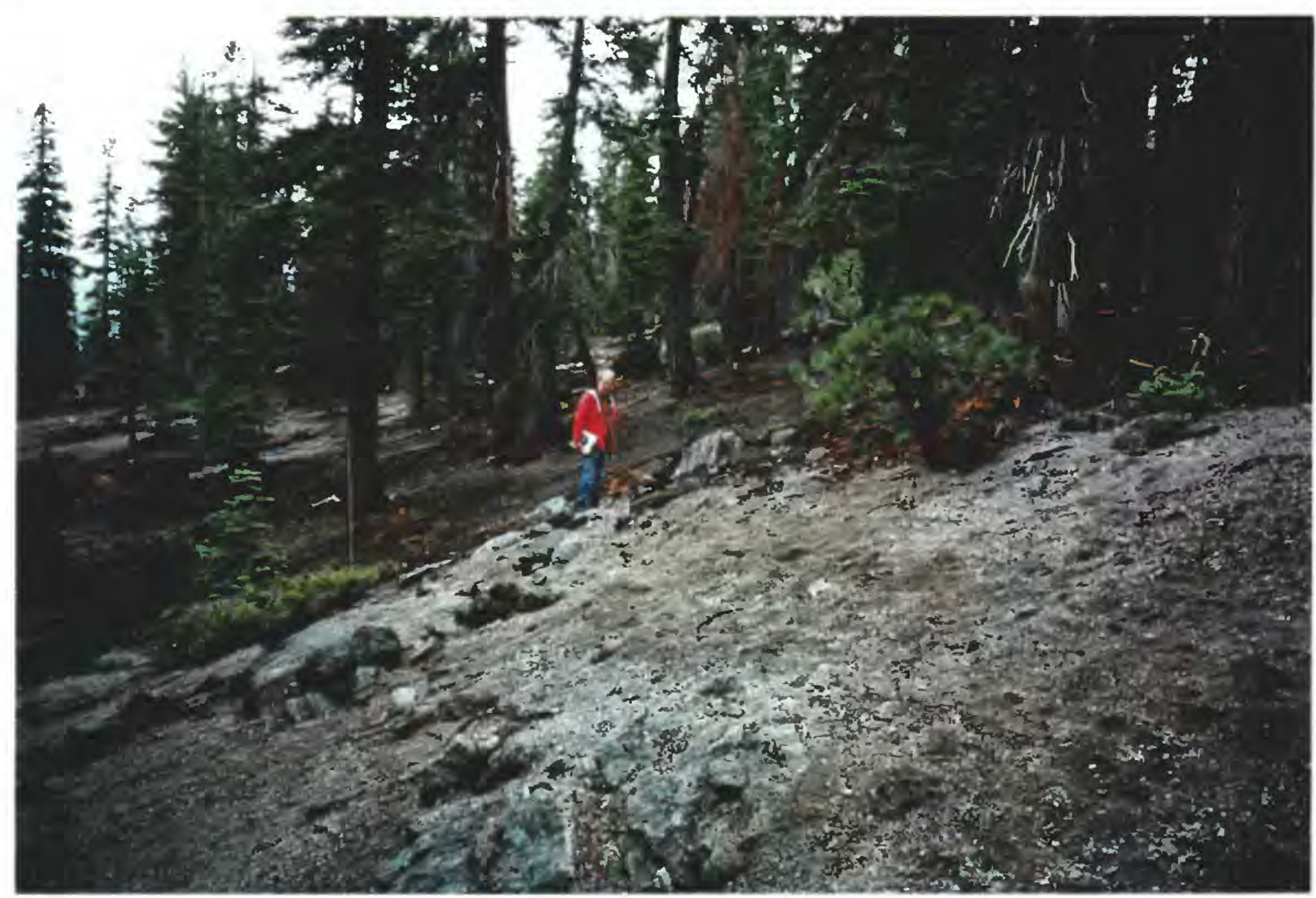

Photo 2.2

MM02 Earthquake Fault: From Earthquake Fault entrance,. drive north $1.0 \mathrm{~km}(0.6 \mathrm{mi})$ along 4WD trail and park on left oppposite large boulder (Photos 2.1, 2.2). Station was on a rhyolite outcrop (Photo 2.3) about 50 meters ahead of the truck's location in Photos $2.1 \& 2.2$. 


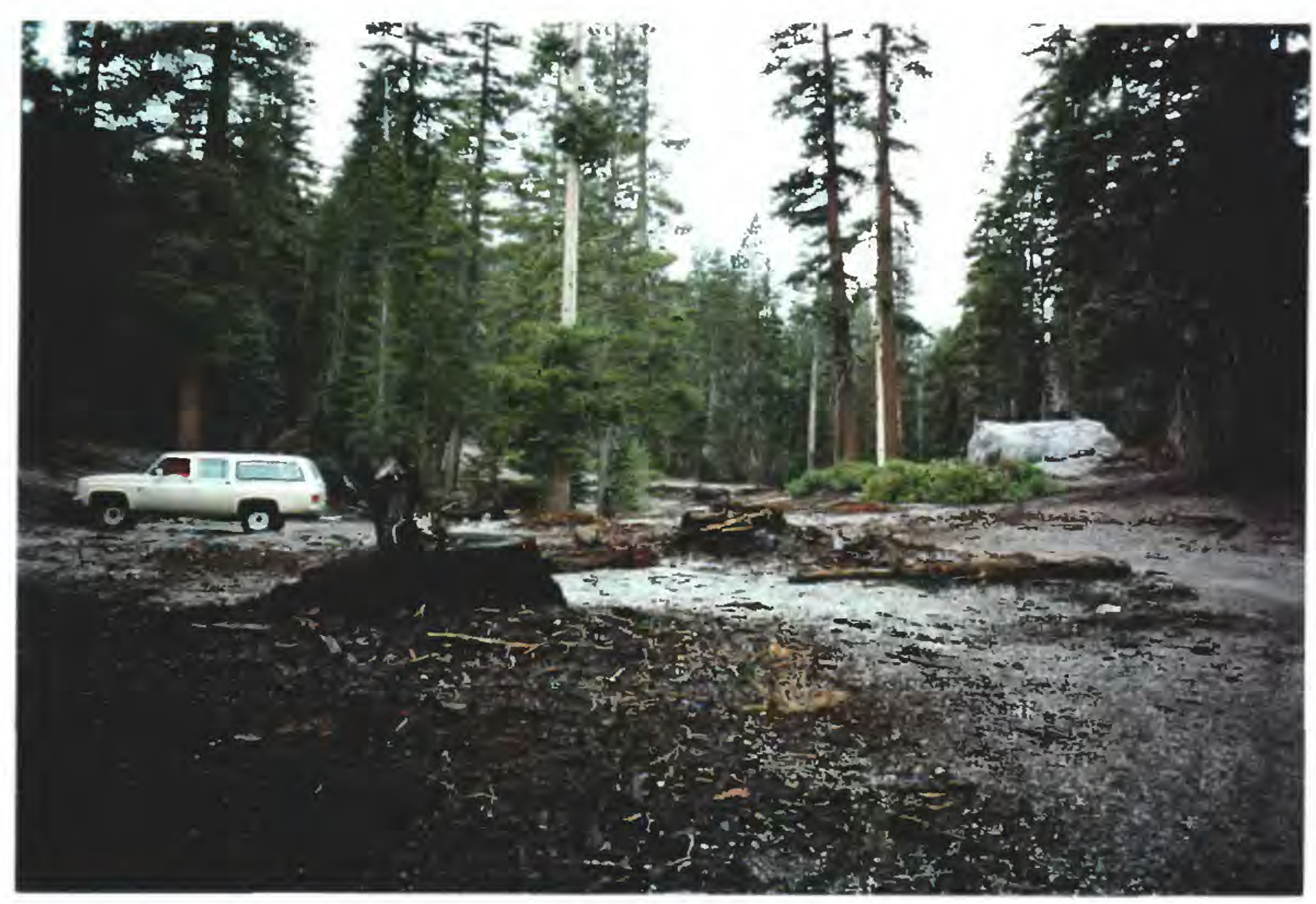

Photo 2.3

MM02 Earthquake Fault (continued). 


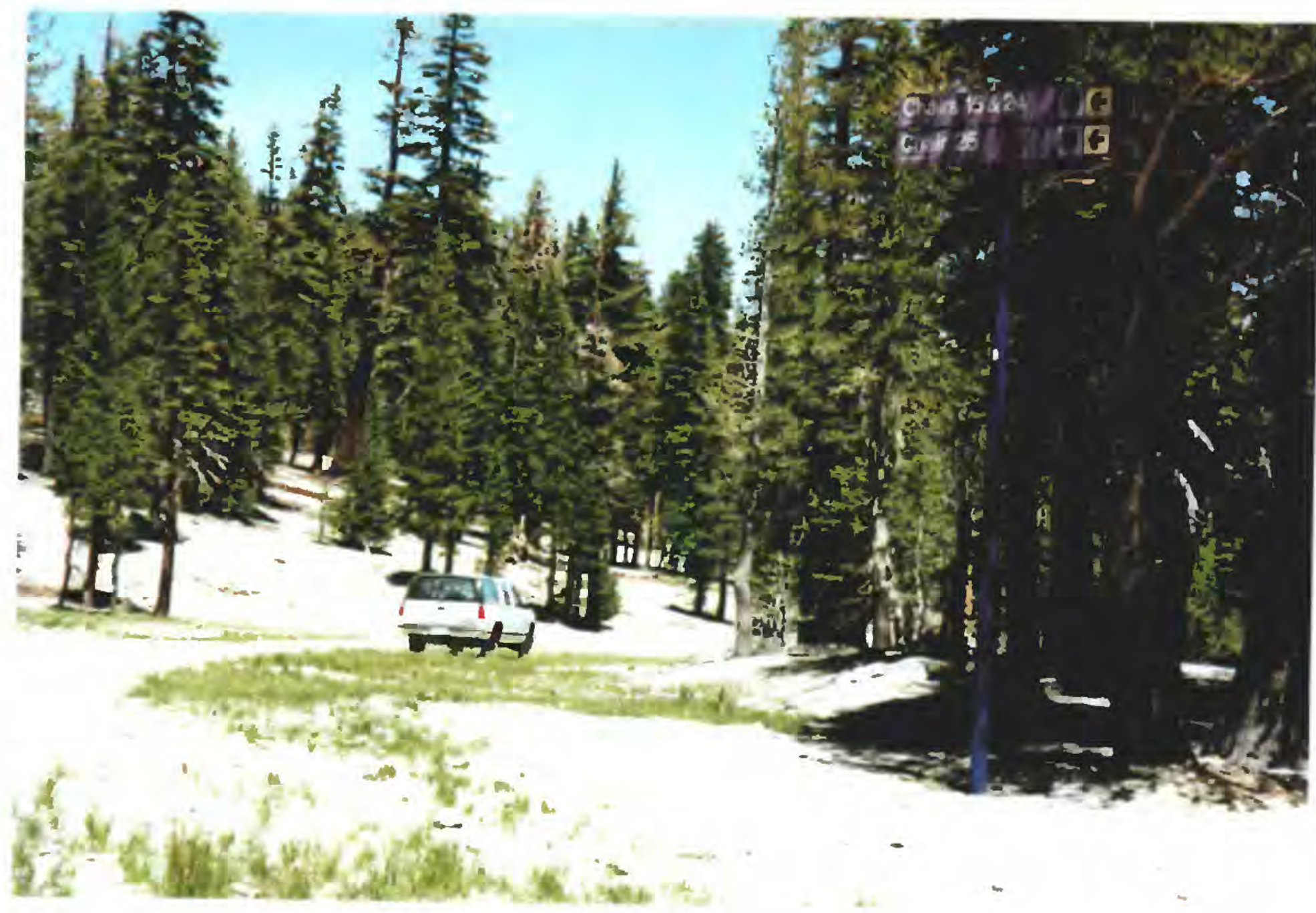

Photo 3.1

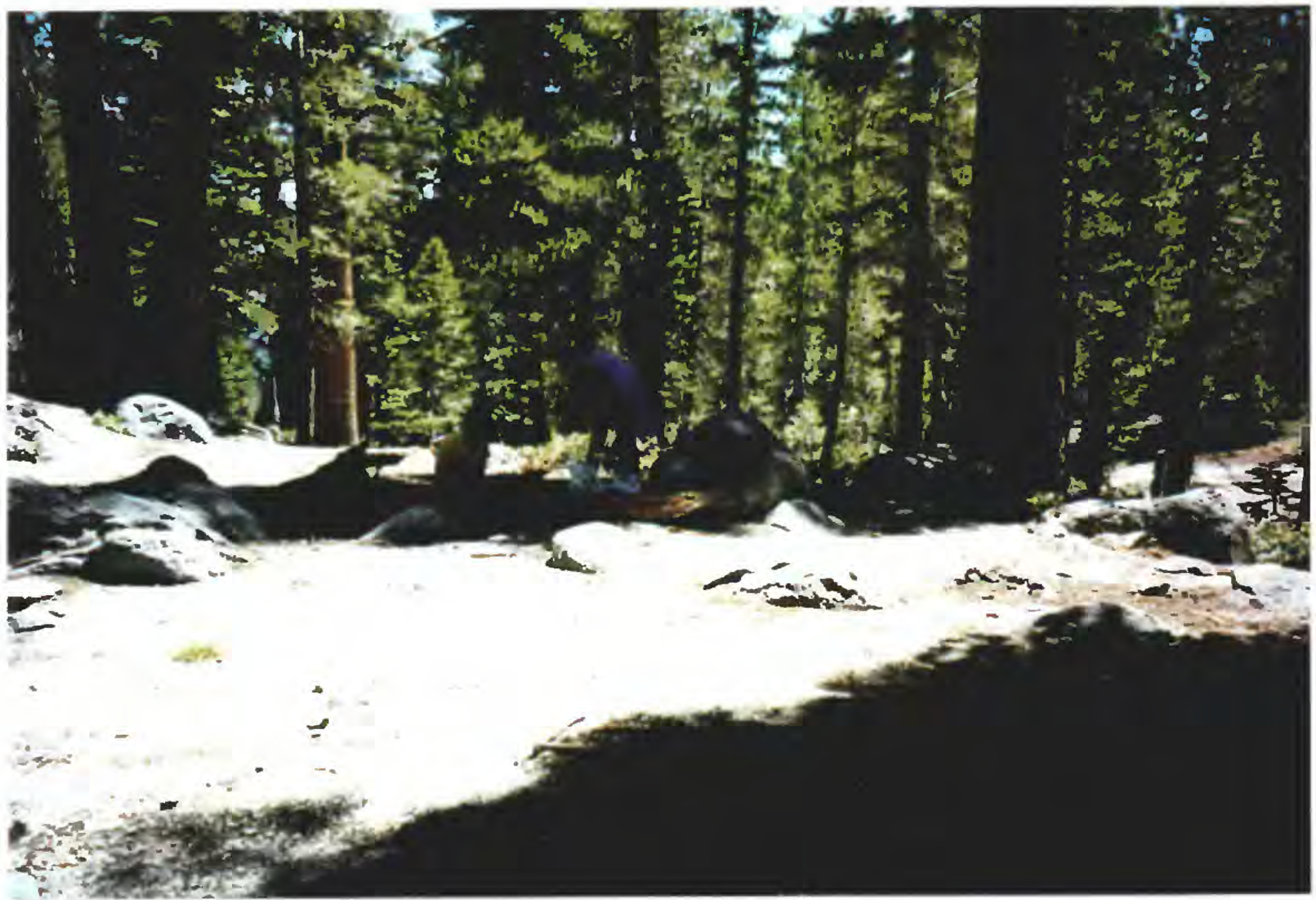

Photo 3.2

MM03 Ski Lifts: Follow the road marked on the map south to a hairpin turn to the left. After the turn, park just past the sign to chairlifts $15 \& 24$ and 25 (Photo 3.1). The station was about 20 meters into the woods to the right of the truck, on an outcrop or large boulder (Photo 3.2). 


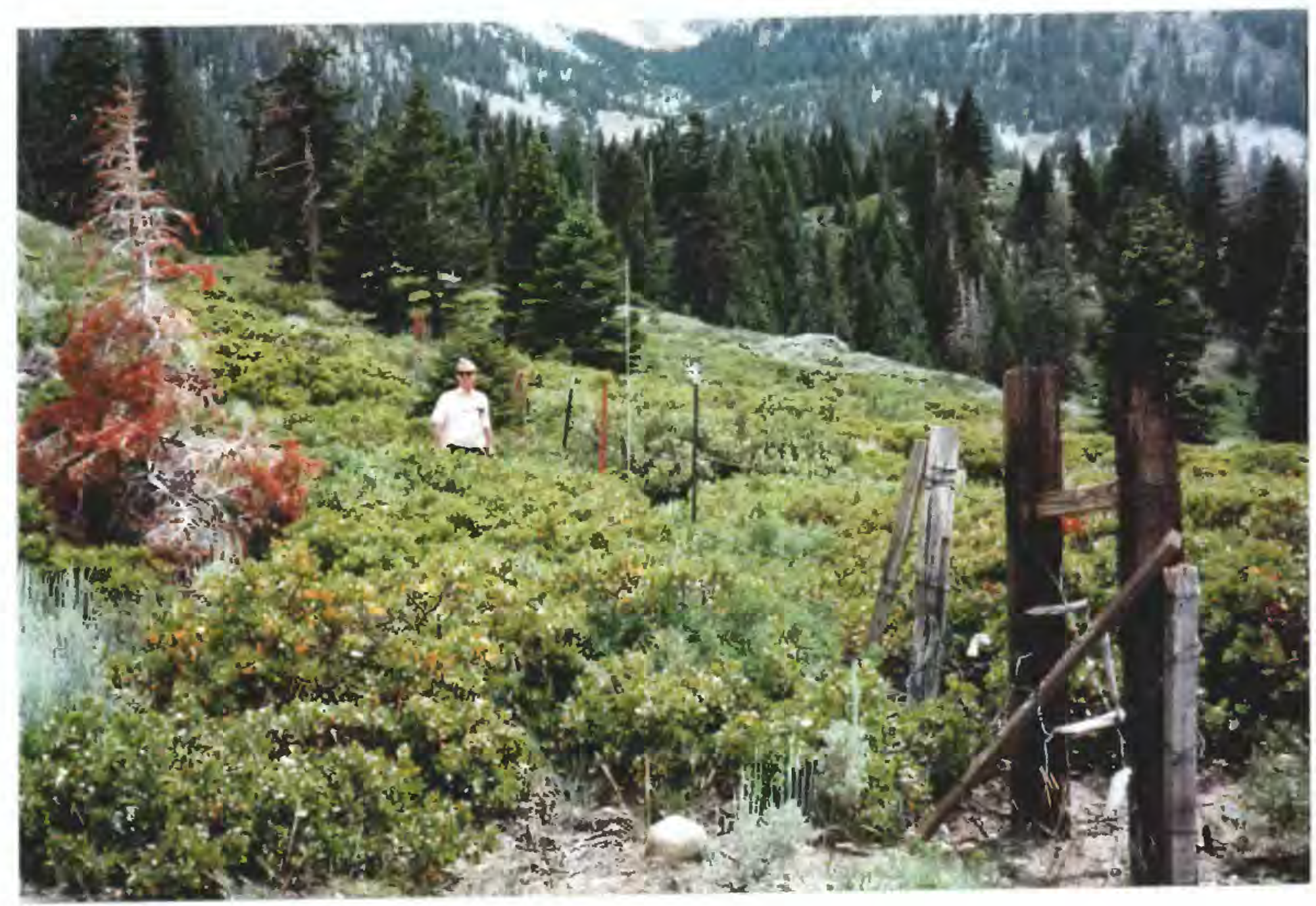

Photo 4.1

MM04 Corrals: Station was about 15 meters south of road, near figure (Photo 4.1). 


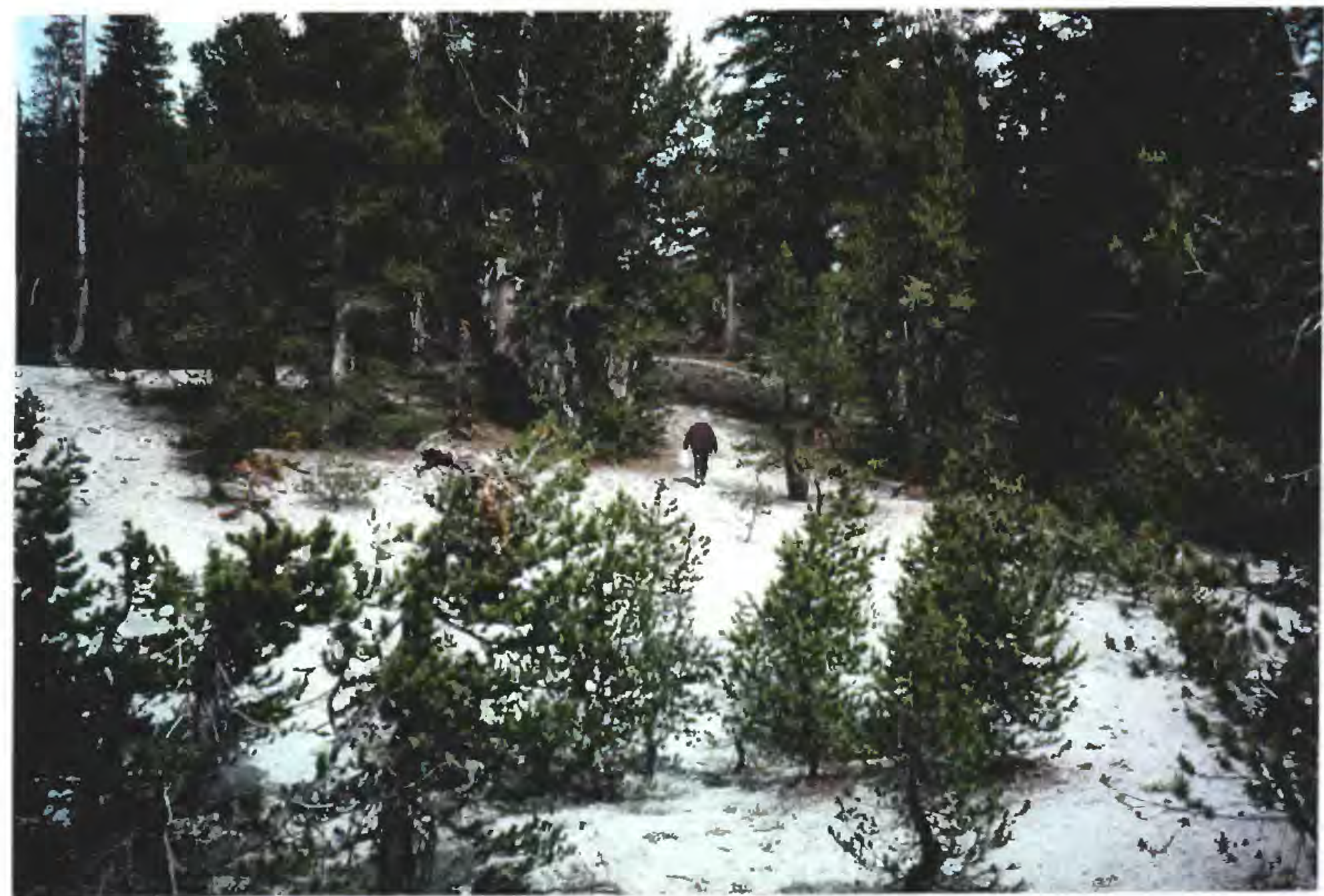

Photo 5.1

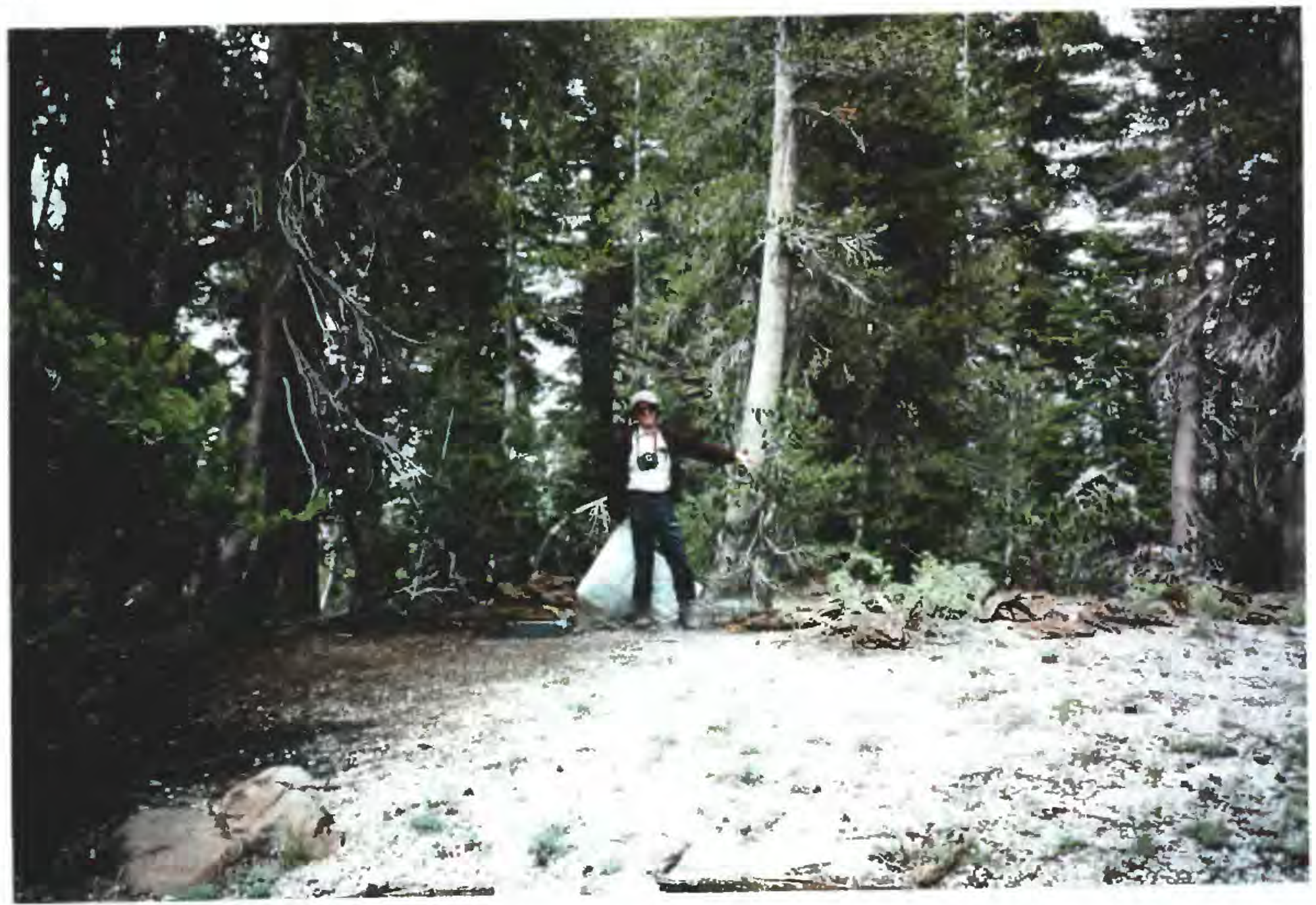

Photo 5.2

MM05 Minaret Summit: A few meters past the bend in the trail, leave the trail and walk 70 meters to the station on top of the low hill on the right (Photos 5.1, 5.2). 


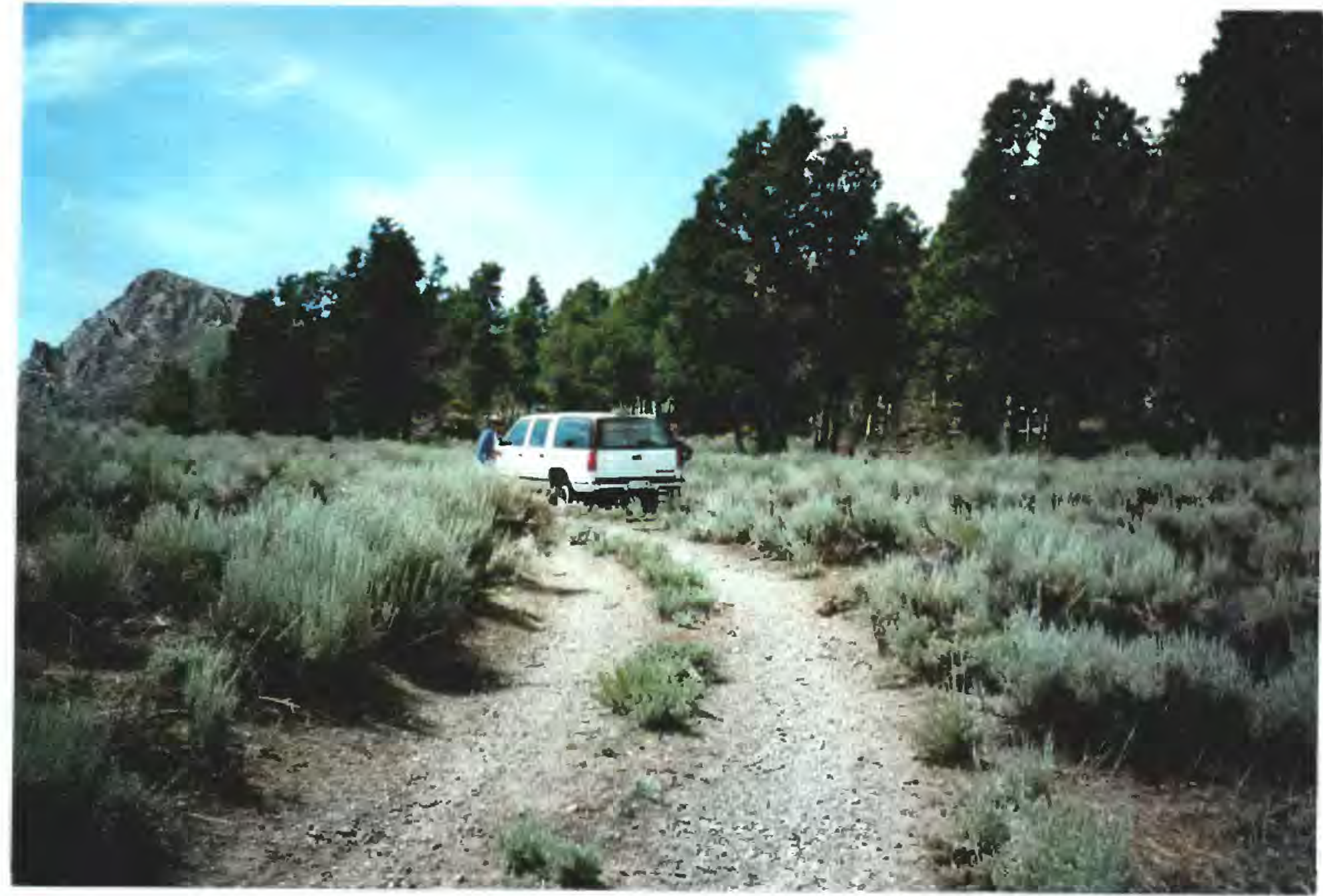

Photo 6.1

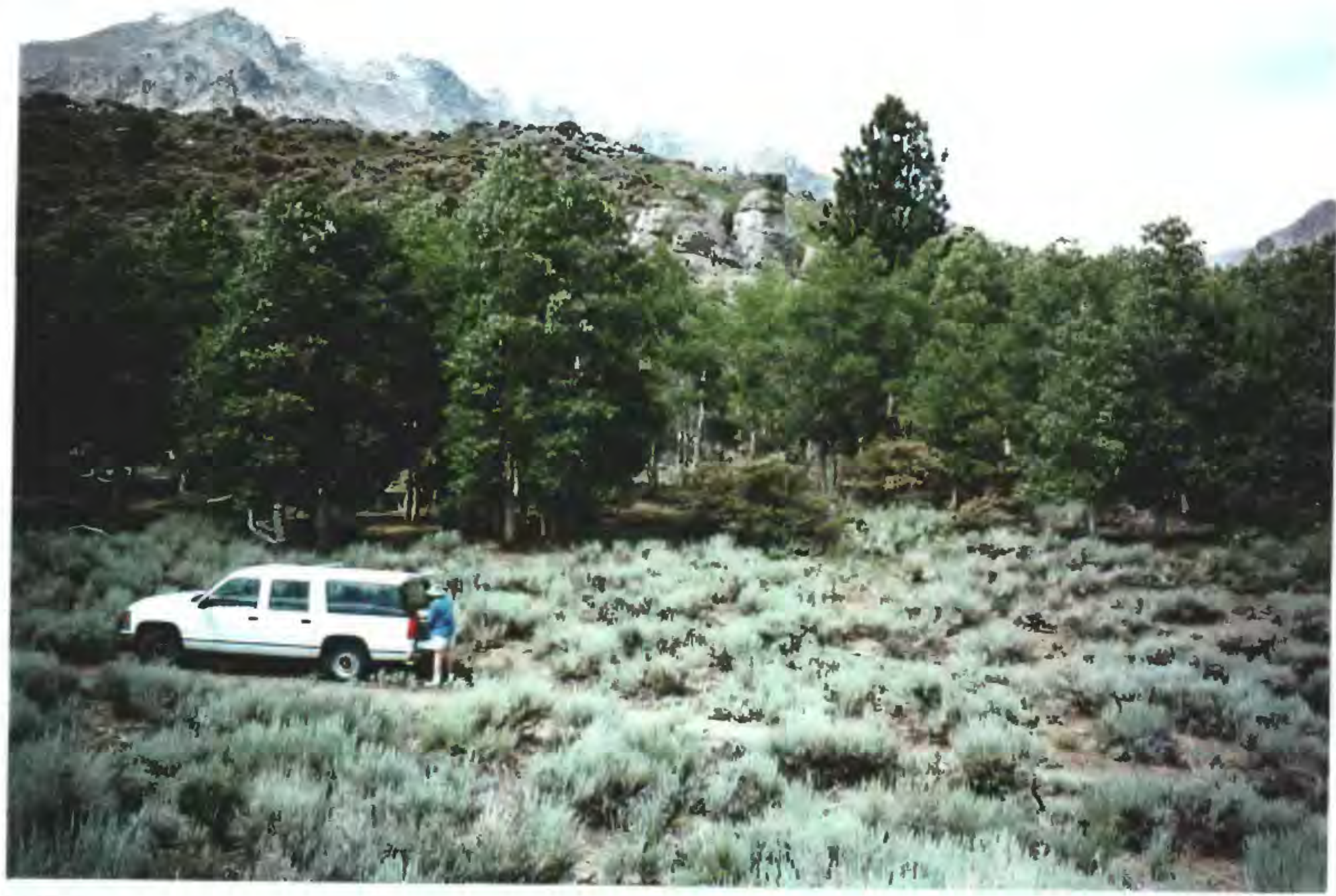

Photo 6.2

MM06 Grant Lake: Drive along 4WD road until you meet a small grove on the right (west) (Photo 6.1). An outcrop with a distinctive capped pinnacle lies behind this wood. It is not visible from the road but can be seen clearly from the slope to the left (east) of the road (Photo 6.2). The station was at the foot of the capped pinnacle (Photo 6.3). 


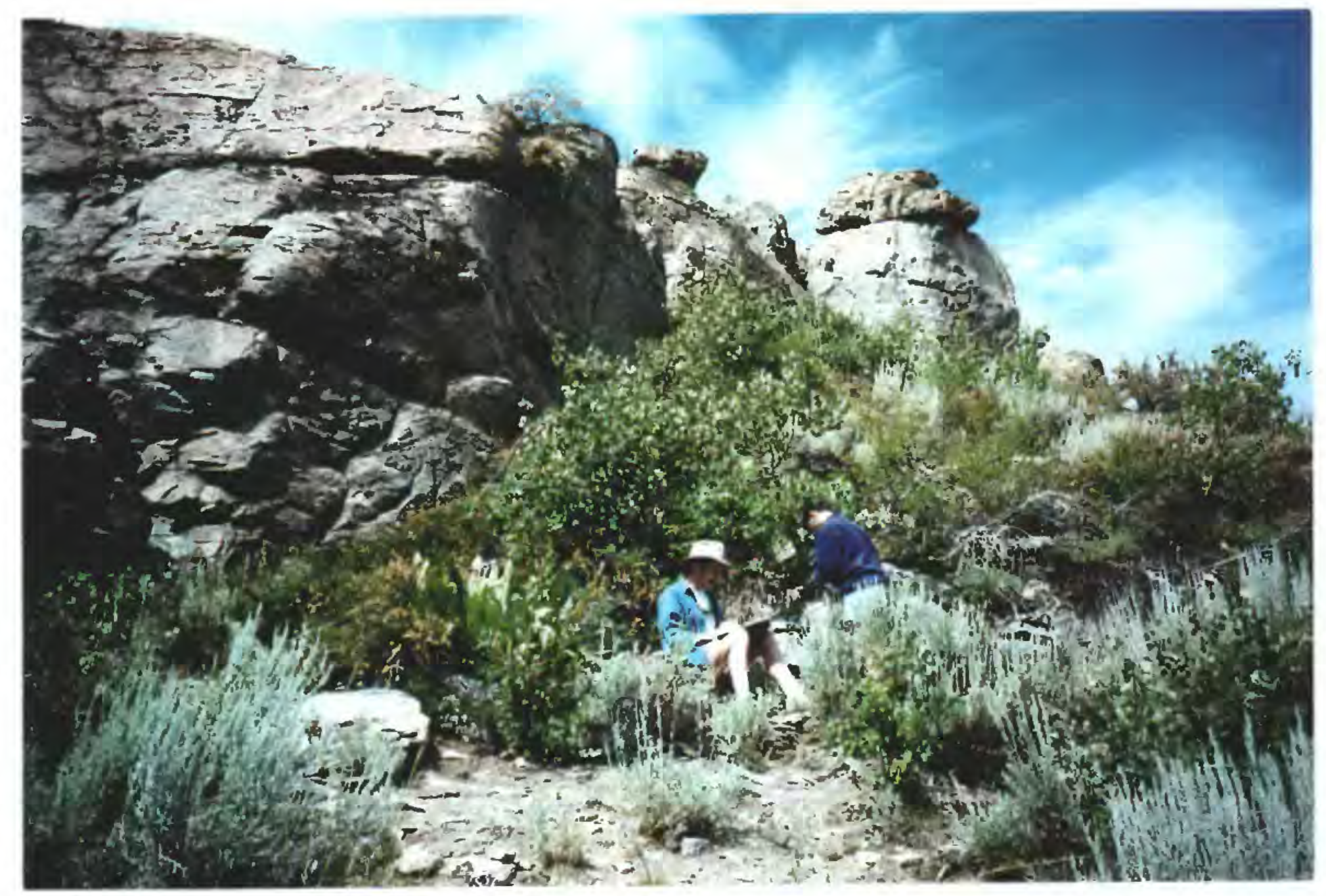

Photo 6.3

MM06 Grant Lake (continued). 


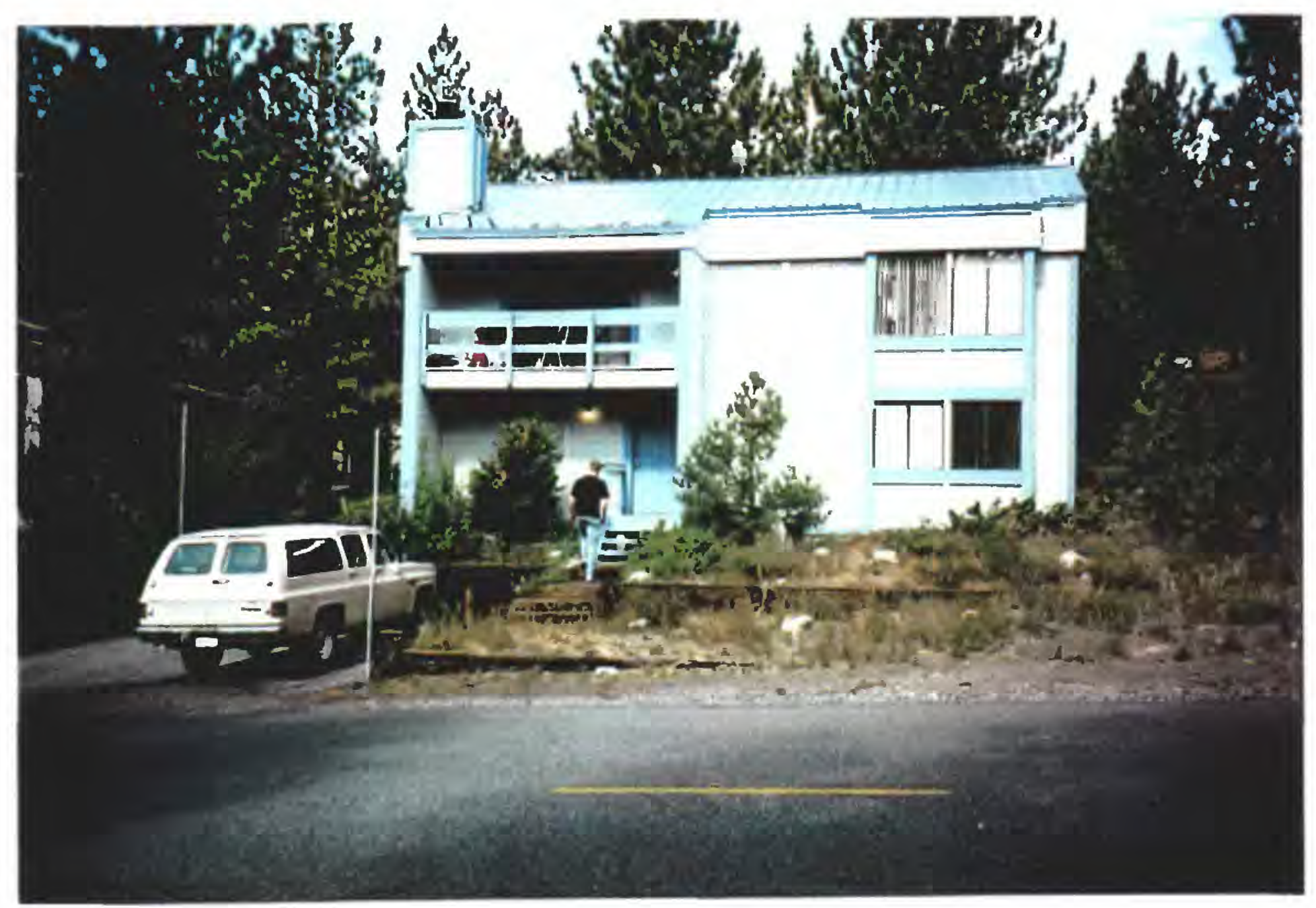

Photo 7.1

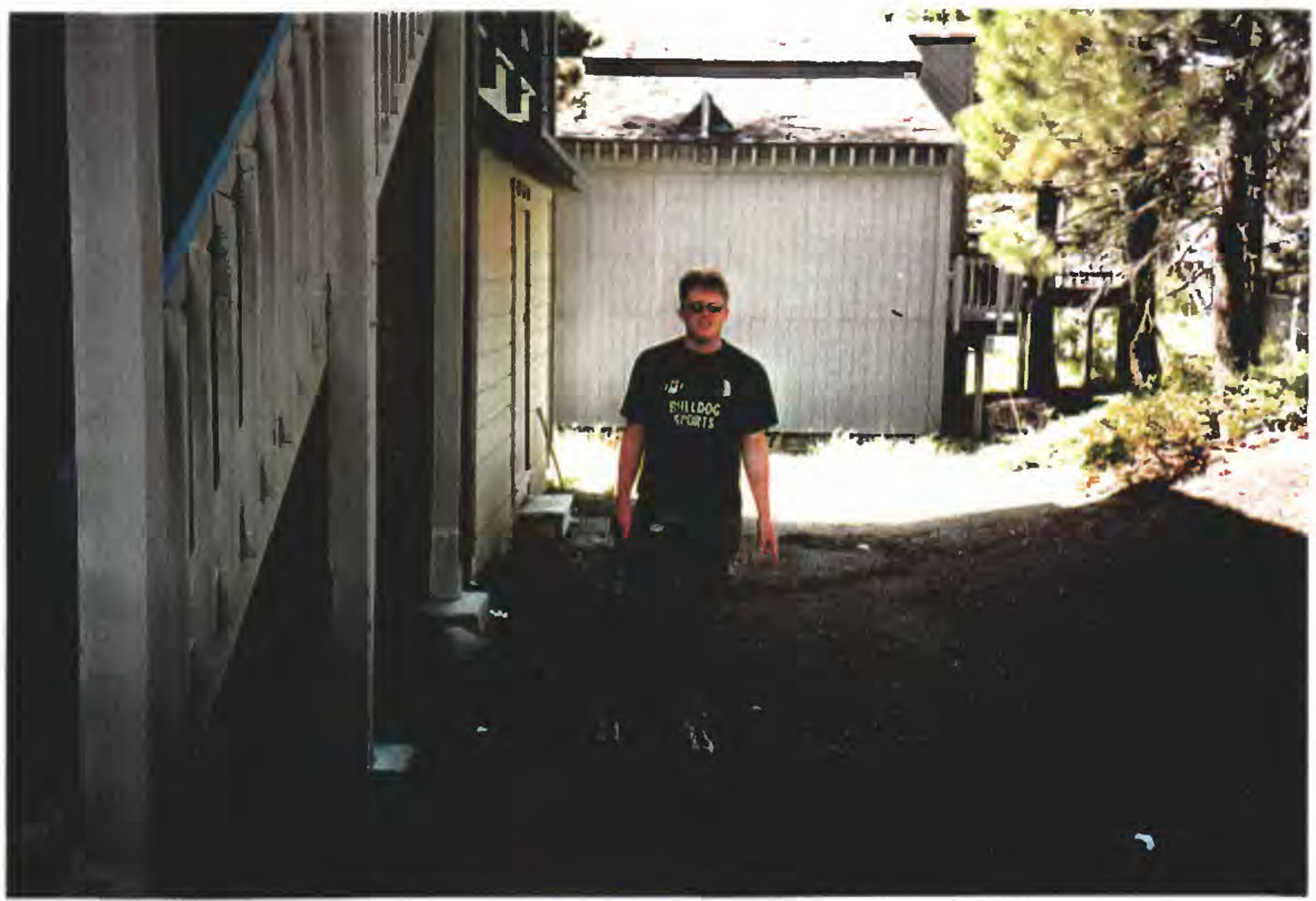

Photo 7.2

MM07 Backyard: Immediately behind house at 1191 Majestic Pines (Photos 7.1 \& 7.2). 


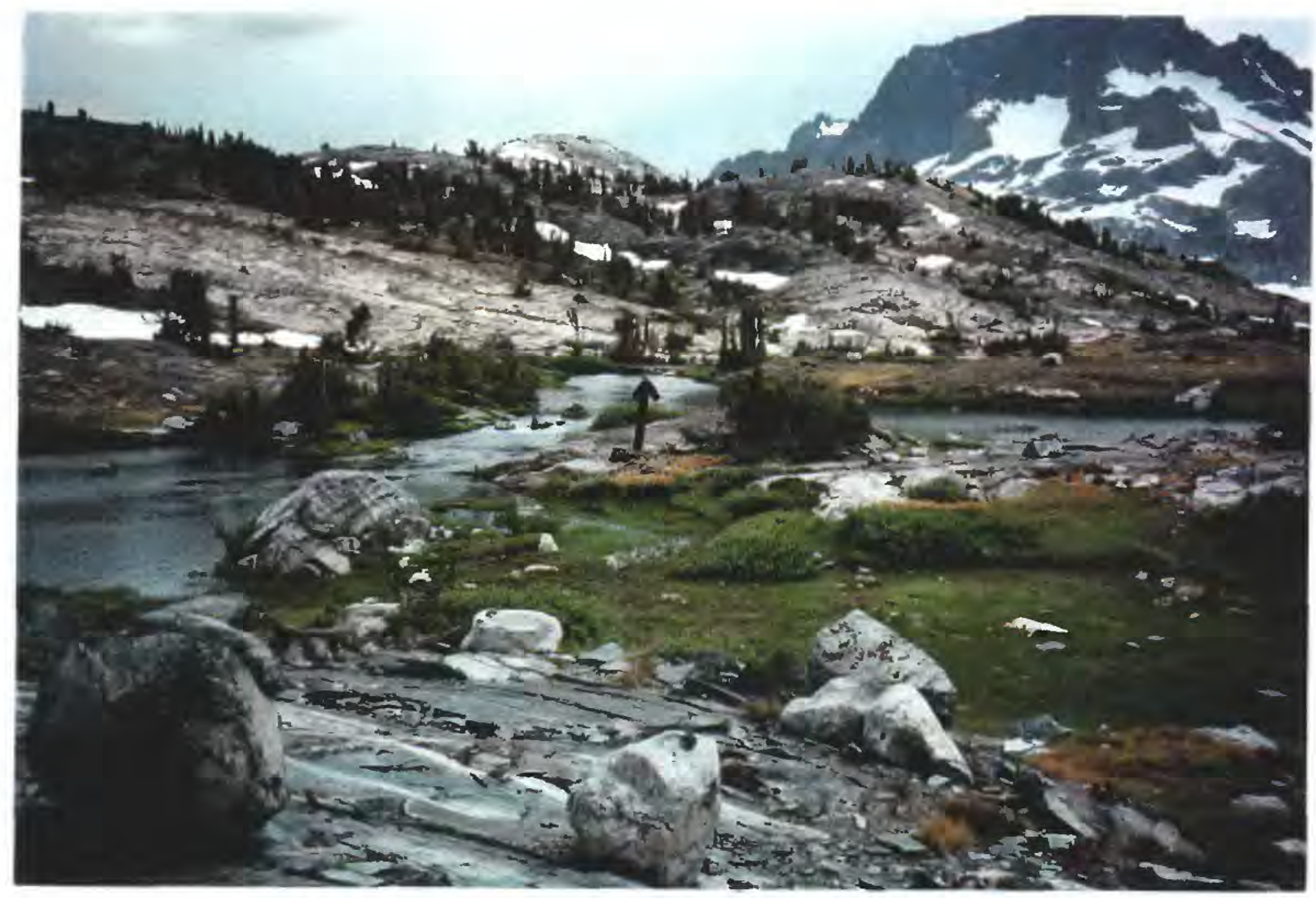

Photo 8.1

MM08 Thousand Island Lake: About 3 hours walk from Agnew Meadow via the River Trail, a small footbridge across the outflow from Thousand Island Lake comes into sight (Photo 8.1). Climb the gully on the right and cross the saddle (Photo 8.2, next page). The station was on outcrop beside grassy area at the foot of the smooth rock face (Photo 8.3, next page). 


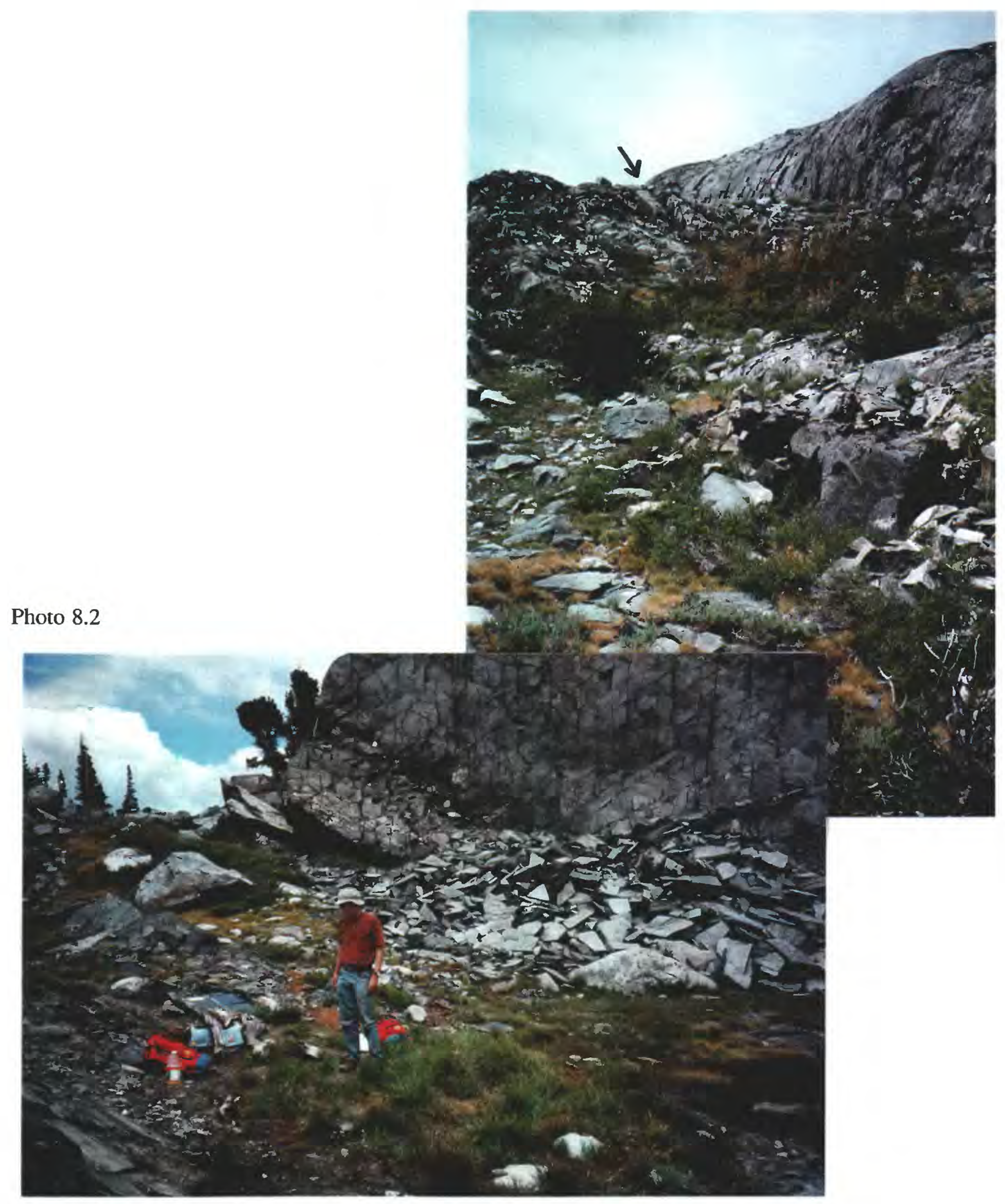

Photo 8.3

MM08 Thousand Island Lake (continued) 


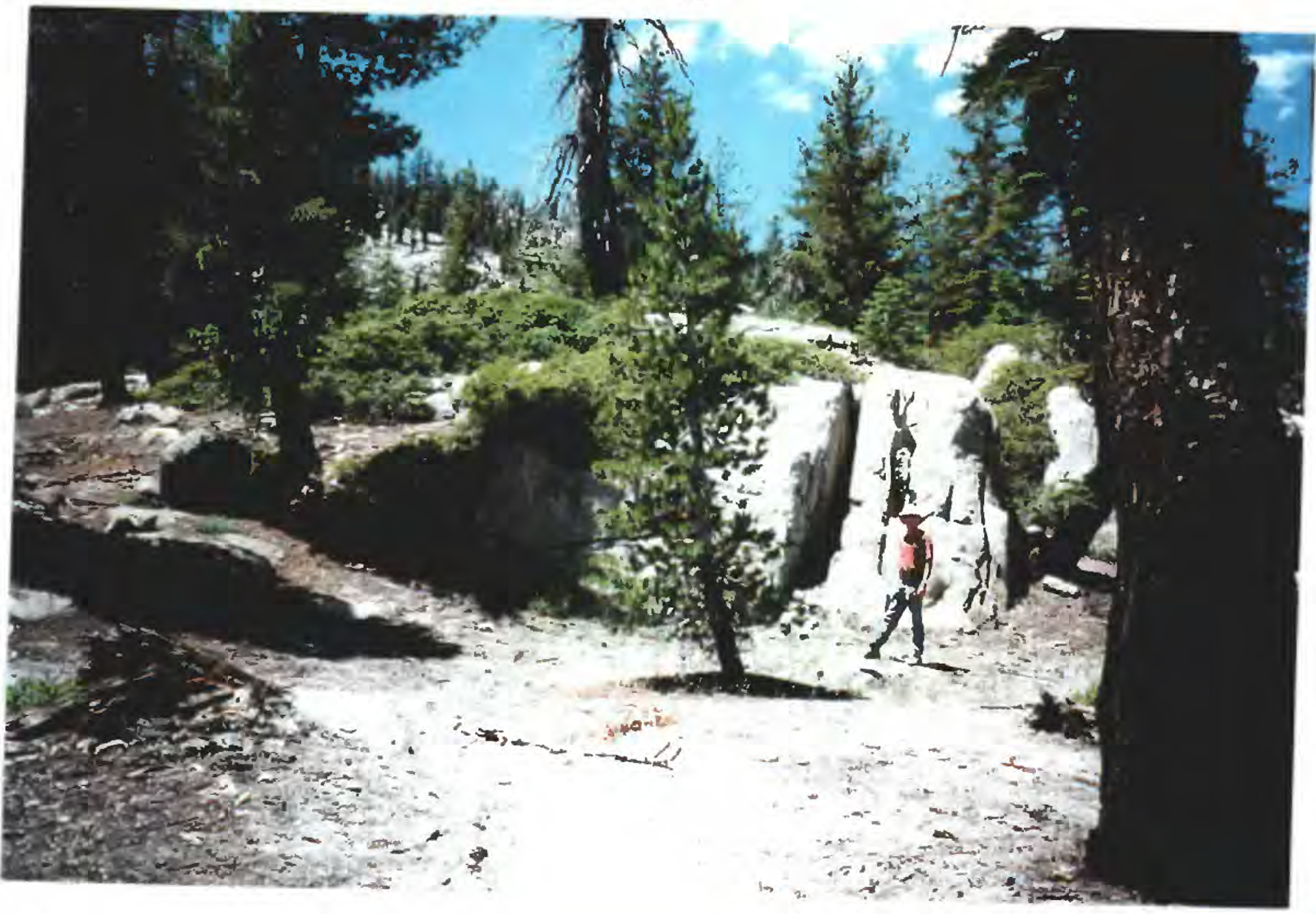

Photo 9.1

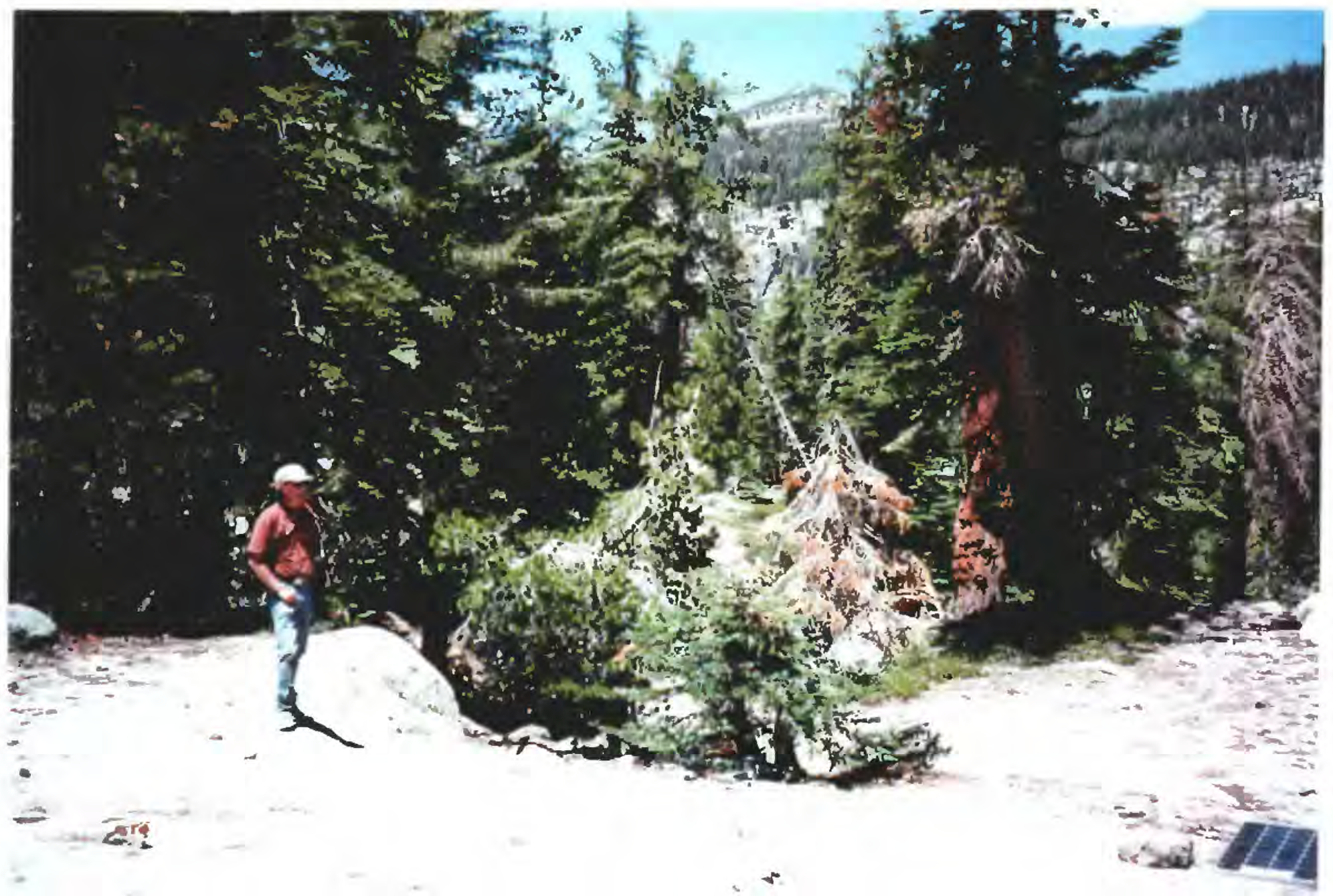

Photo 9.2

MM09 King Creek: The trail climbs steeply to a point where it curves left onto a shoulder. Just before the curve you will see the outcrop shown in Photo 9.1 straight ahead. The station was located on the outcrop, about 30 meters from the trail (Photo 9.2). 


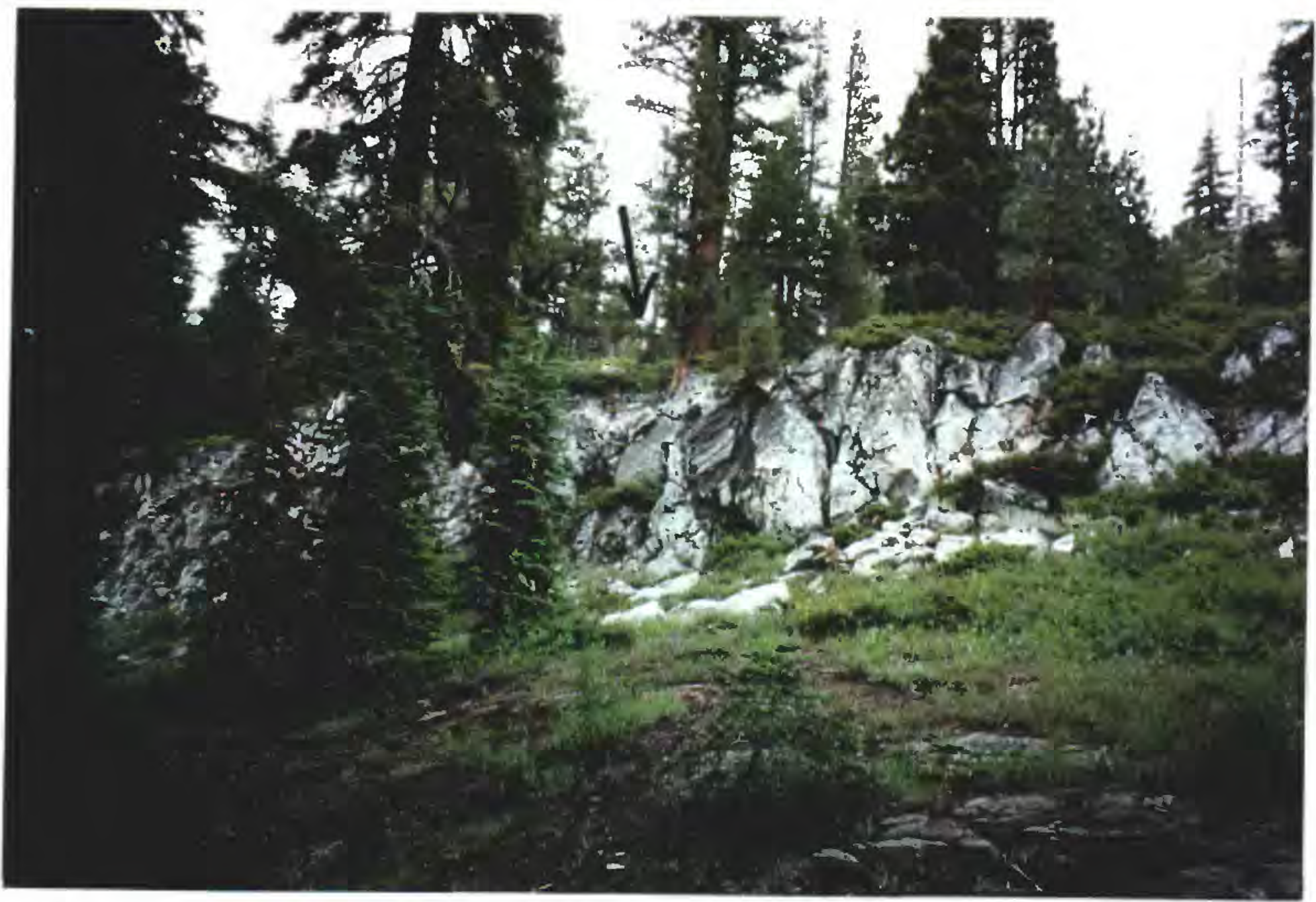

Photo 10.1

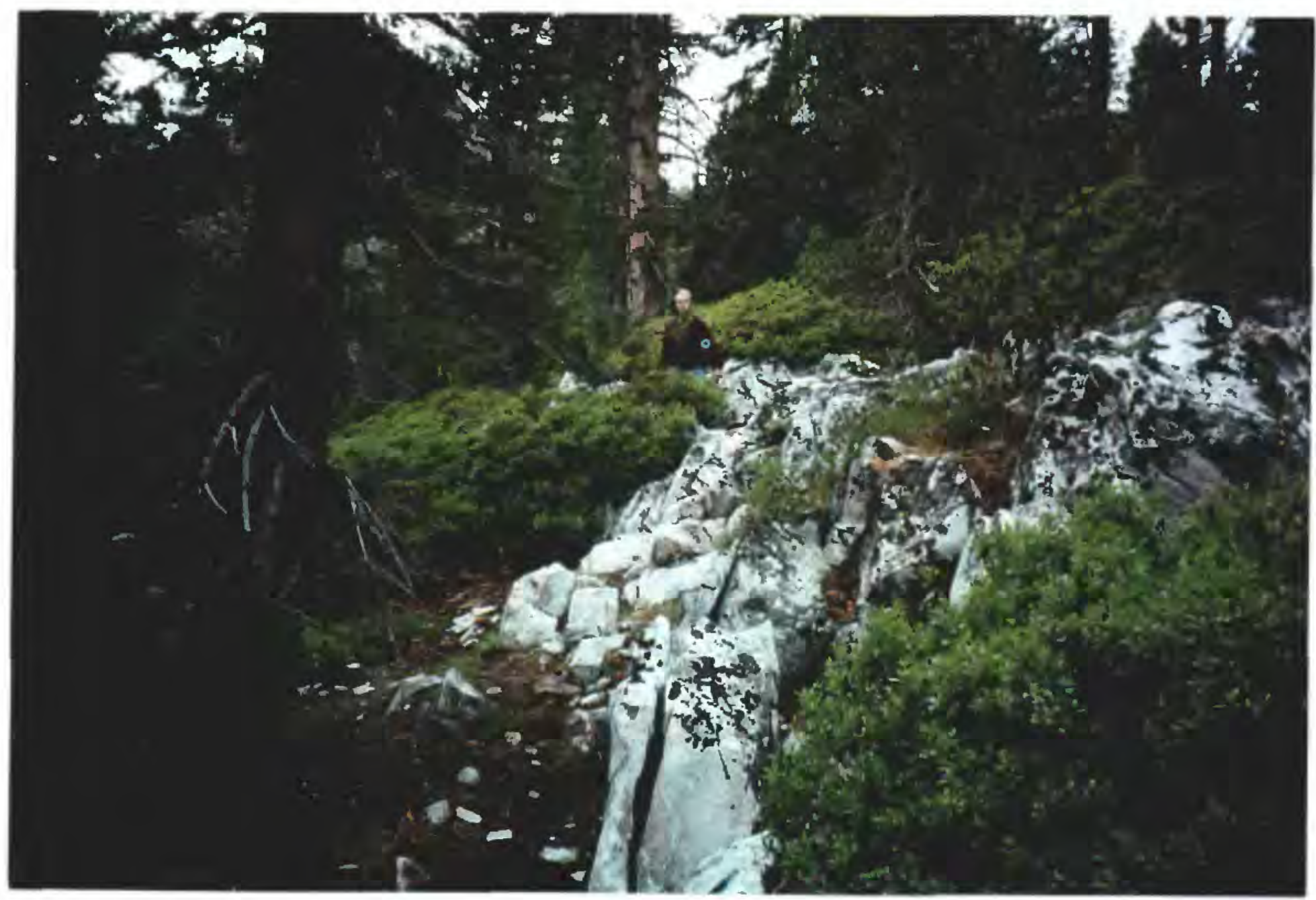

Photo 10.2

MM10 Agnew Meadows: Park at end of road in Agnew Meadows Group Campground. Station was on shoulder of rock above road on right (Photo 10.1). Photo 10.2, showing site location, was taken from a point a few meters to the right of Bruce's position in Photo 10.1. 
Photo 11.1

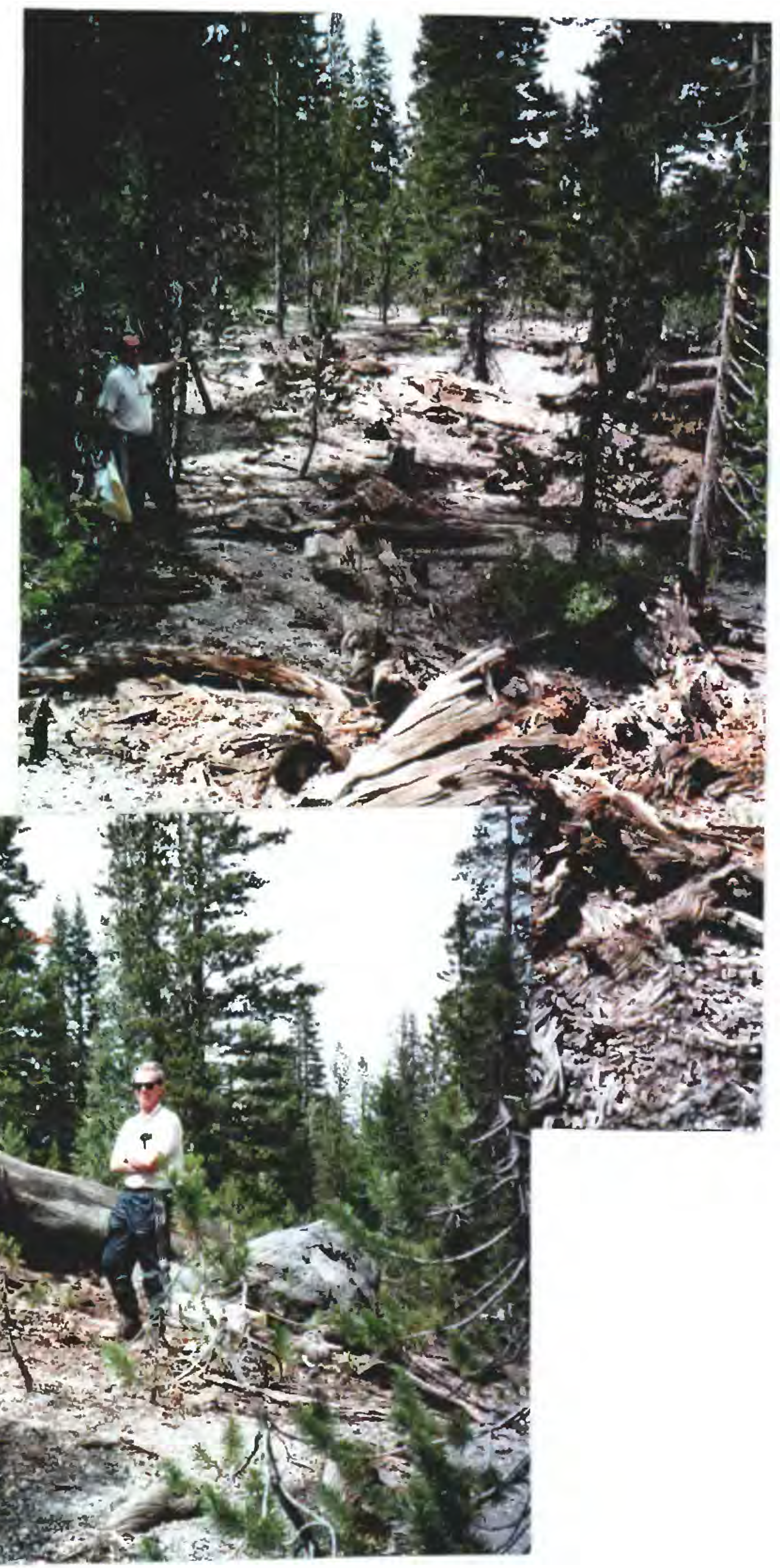

Photo 11.2

MM11 Crater Flat: Park car on right side of loop at the end of the road. Walk at right angles north from the road into the forest (Photo 11.1). The station was located on the first small outcrop you come to, which had a fallen tree on it in 1997 (Photo 11.2). 


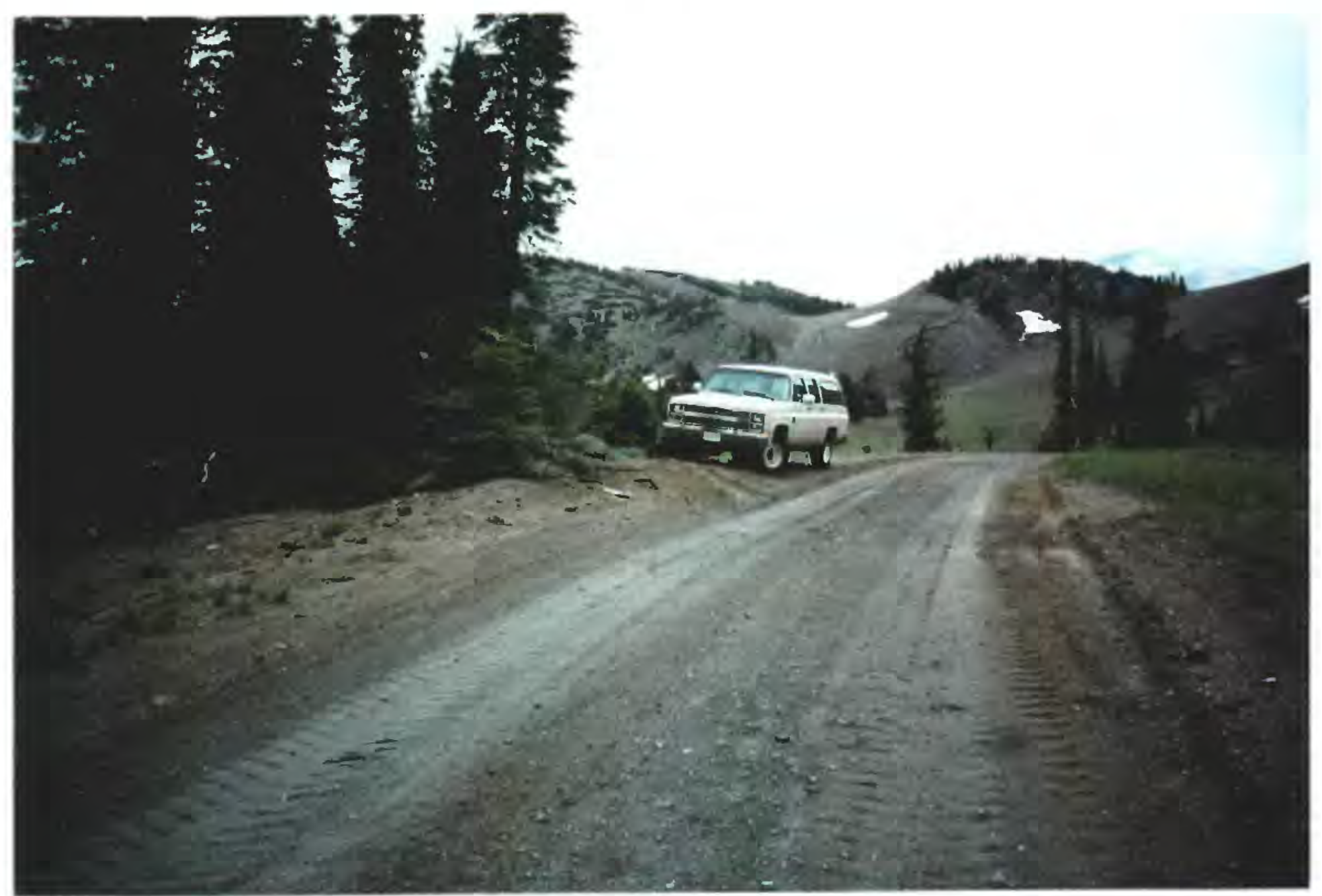

Photo 12.1

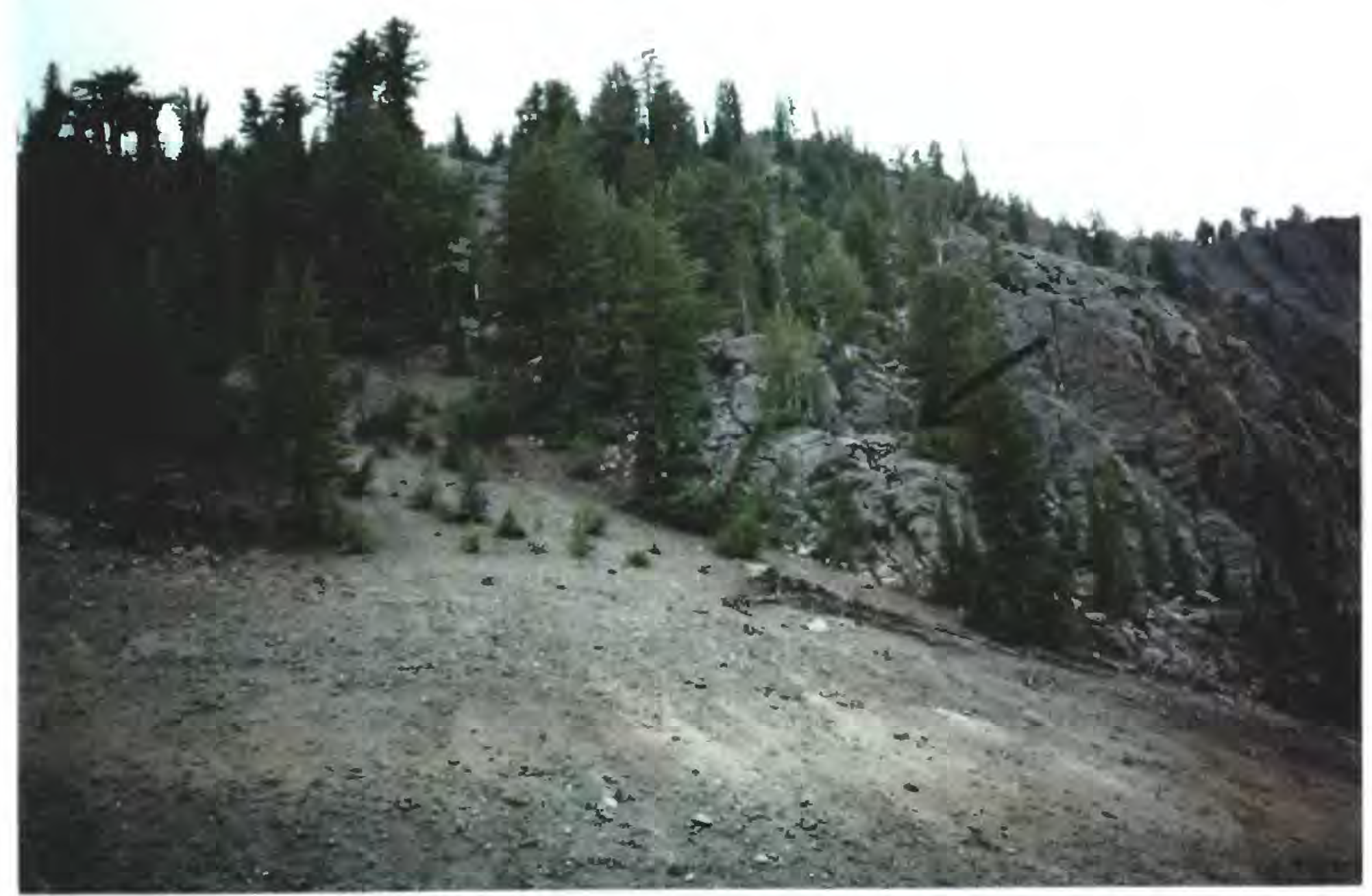

Photo 12.2

MM12 North Mammoth Mountain: Drive to the brow of the hill. At the foot of the ski lift, turn around and park on the right 50 meters down the hill (Photo 12.1). The station was on a rhyolite outcrop west of the road (on the left as you face downhill) (Photo 12.2). 


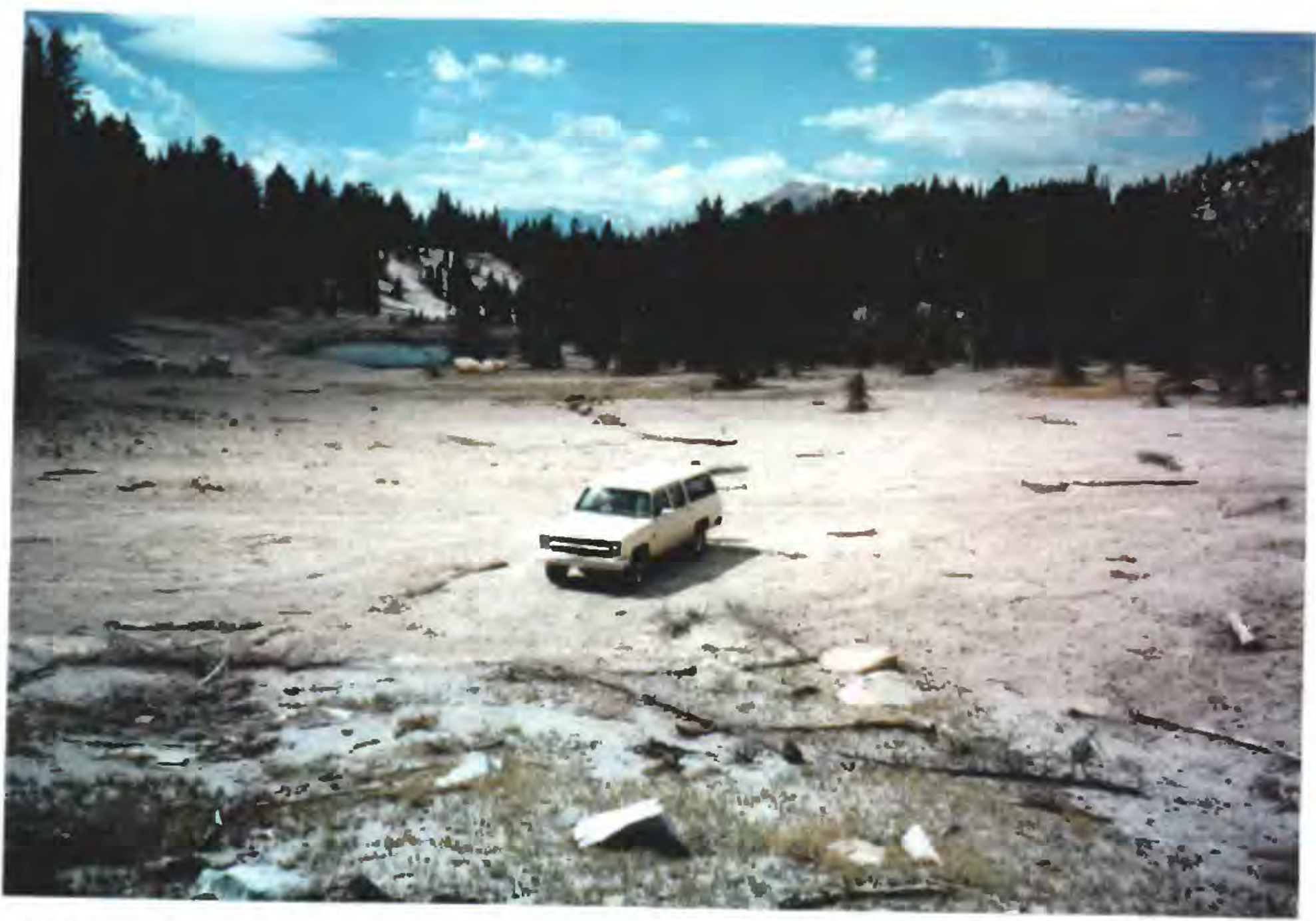

Photo 13.1

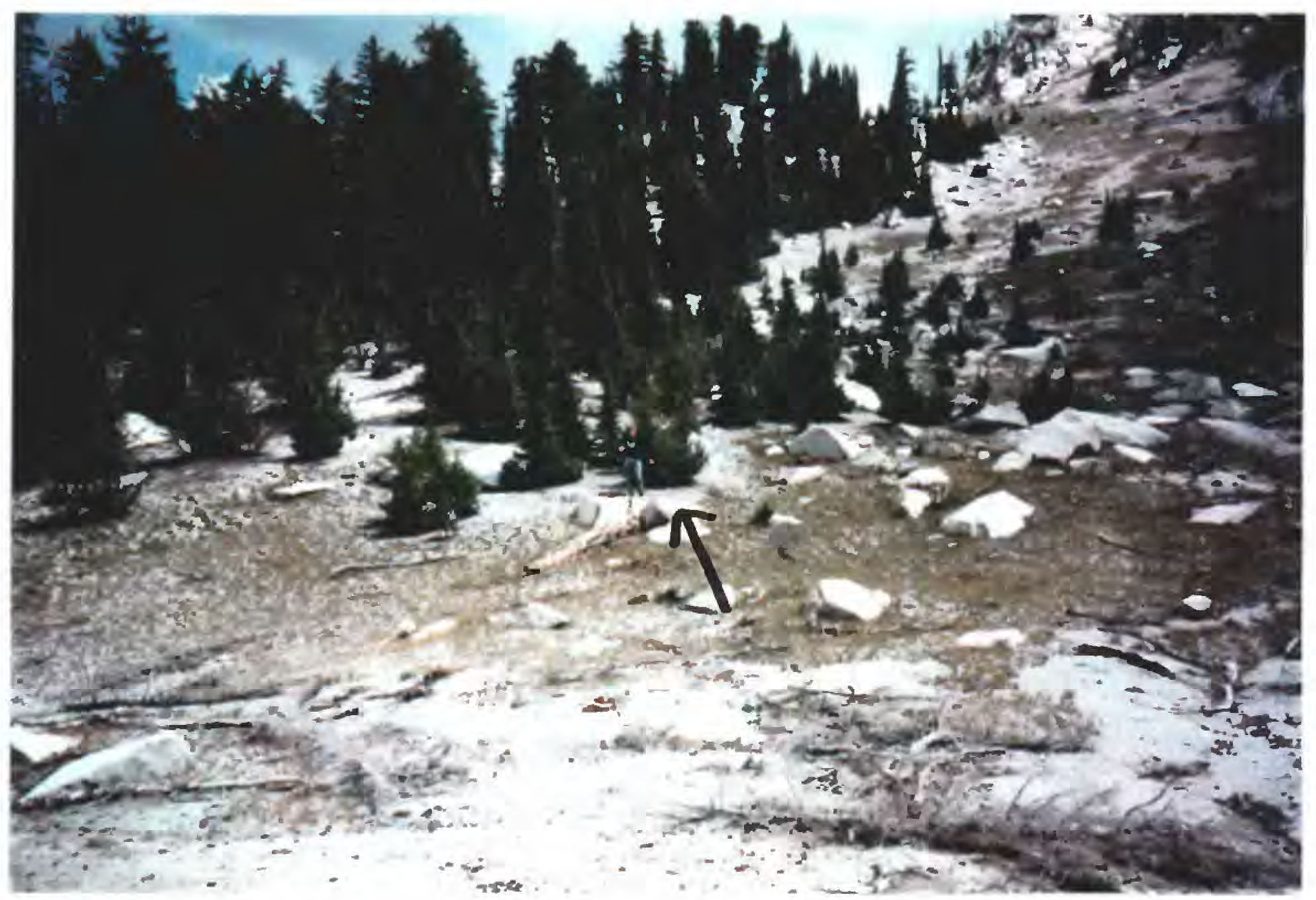

Photo 13.2

MM13 Red's Lake: At the end of the dirt road, park on the sandy flat facing the hillside SSE of Red's Lake (Photo 13.1). Station was on the hillside where Lárus is pointing (Photo 13.2). 


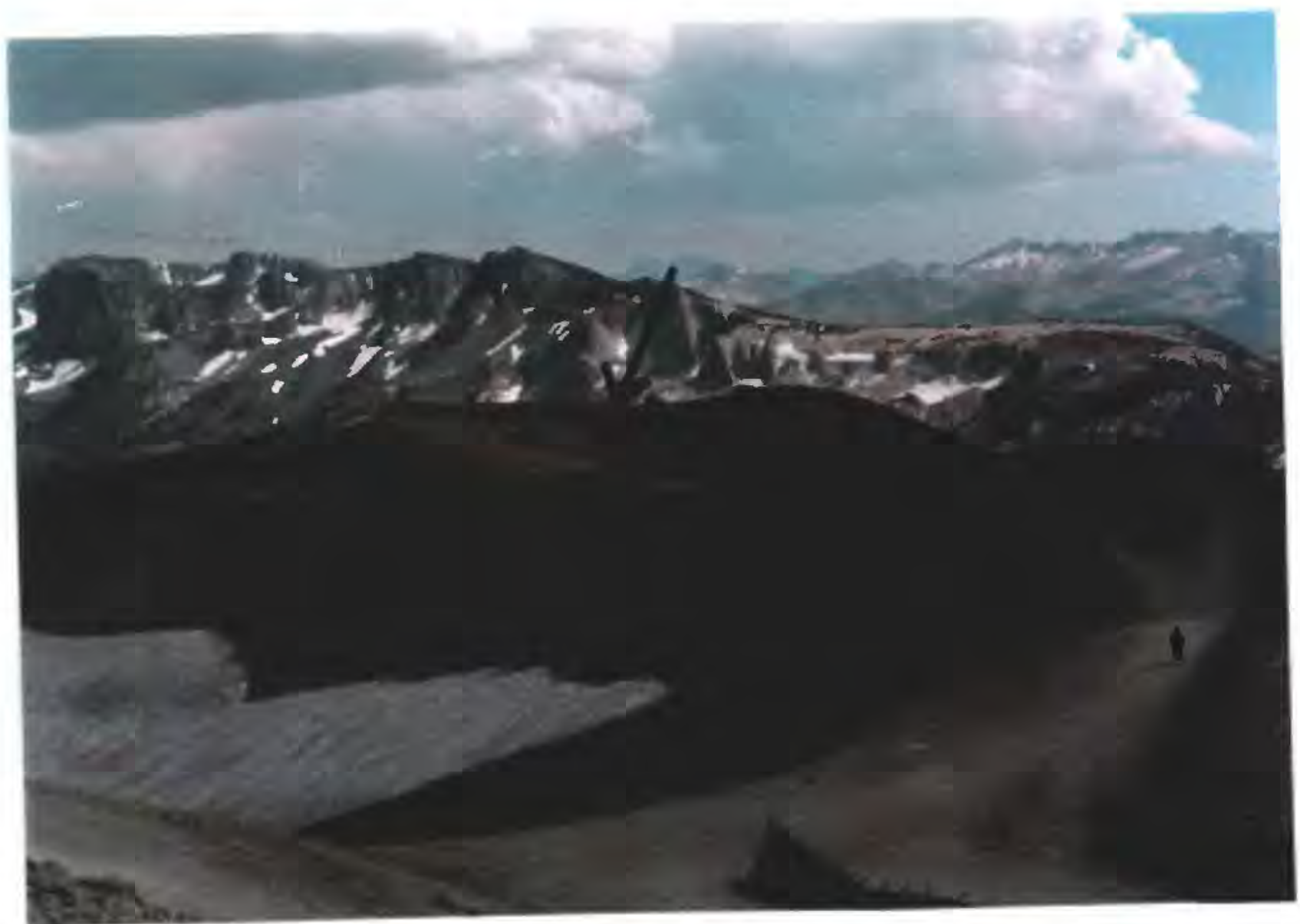

Photo 14.1

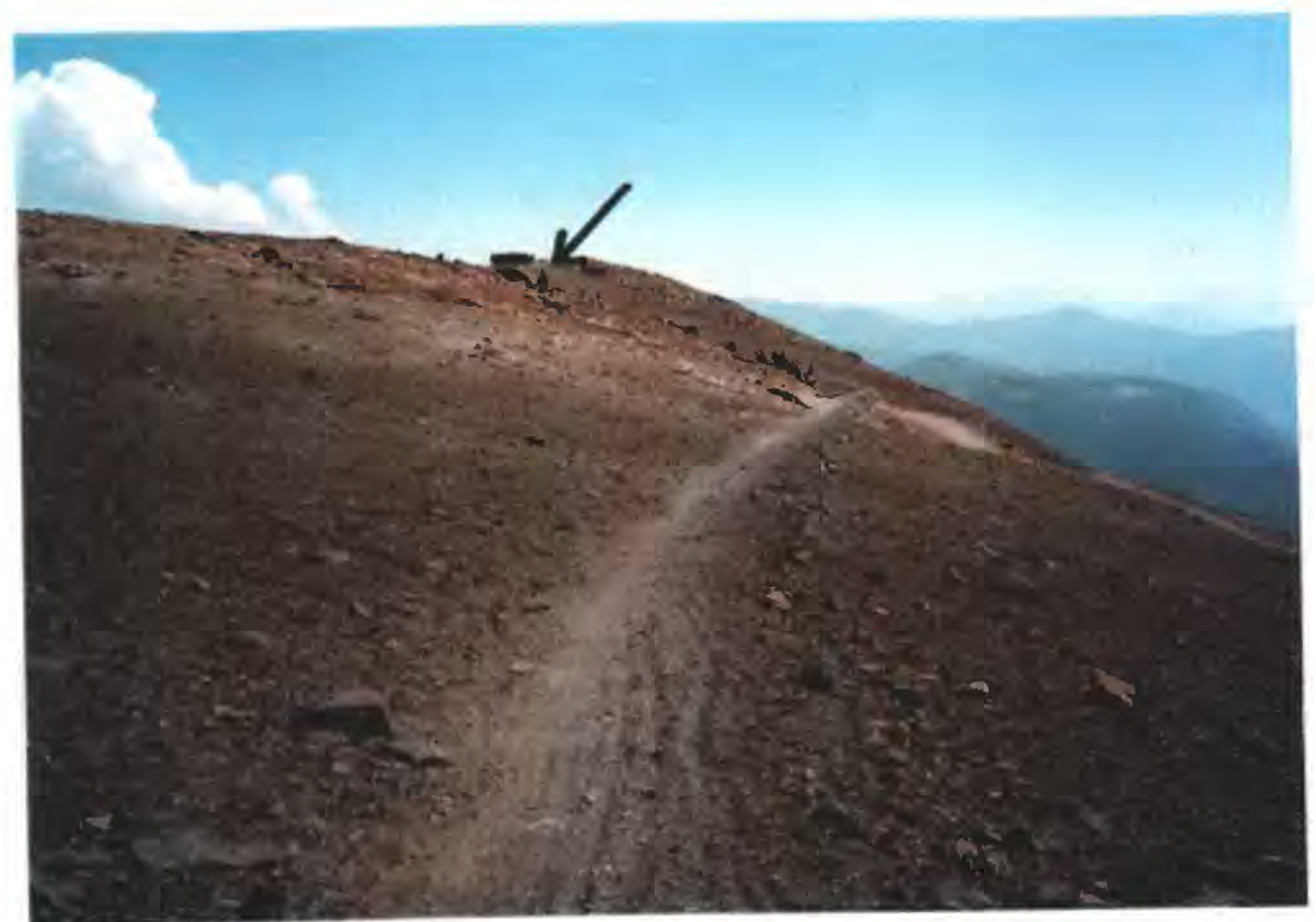

Photo 14.2

MM14 Mammoth Summit: From the gondola building at the summit walk about 500 meters south along the ridge (Photo 14.1). The station was on an outcrop a few meters east of a bike trail (Photos 14.2 and 14.3). 


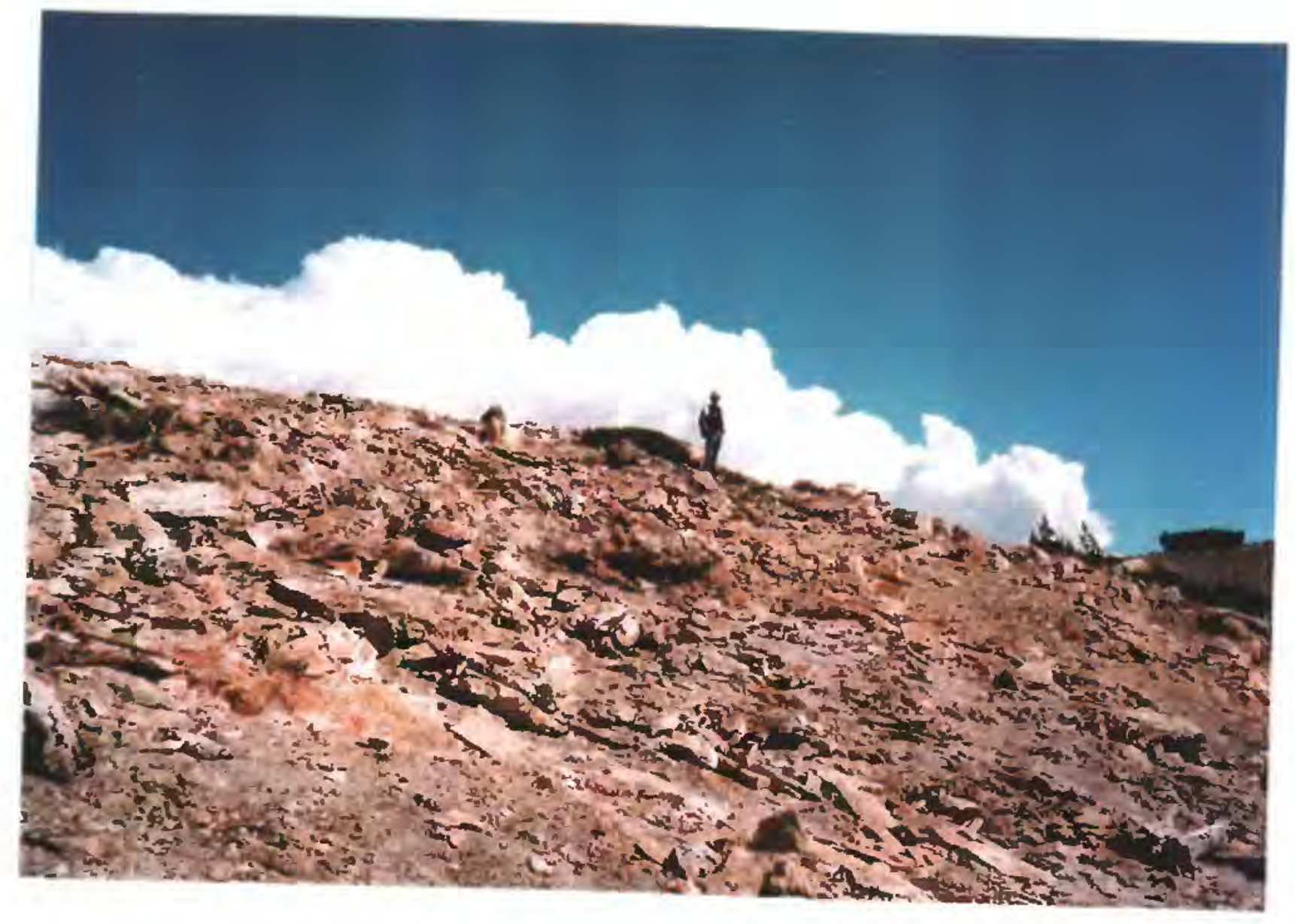

Photo 14.3 


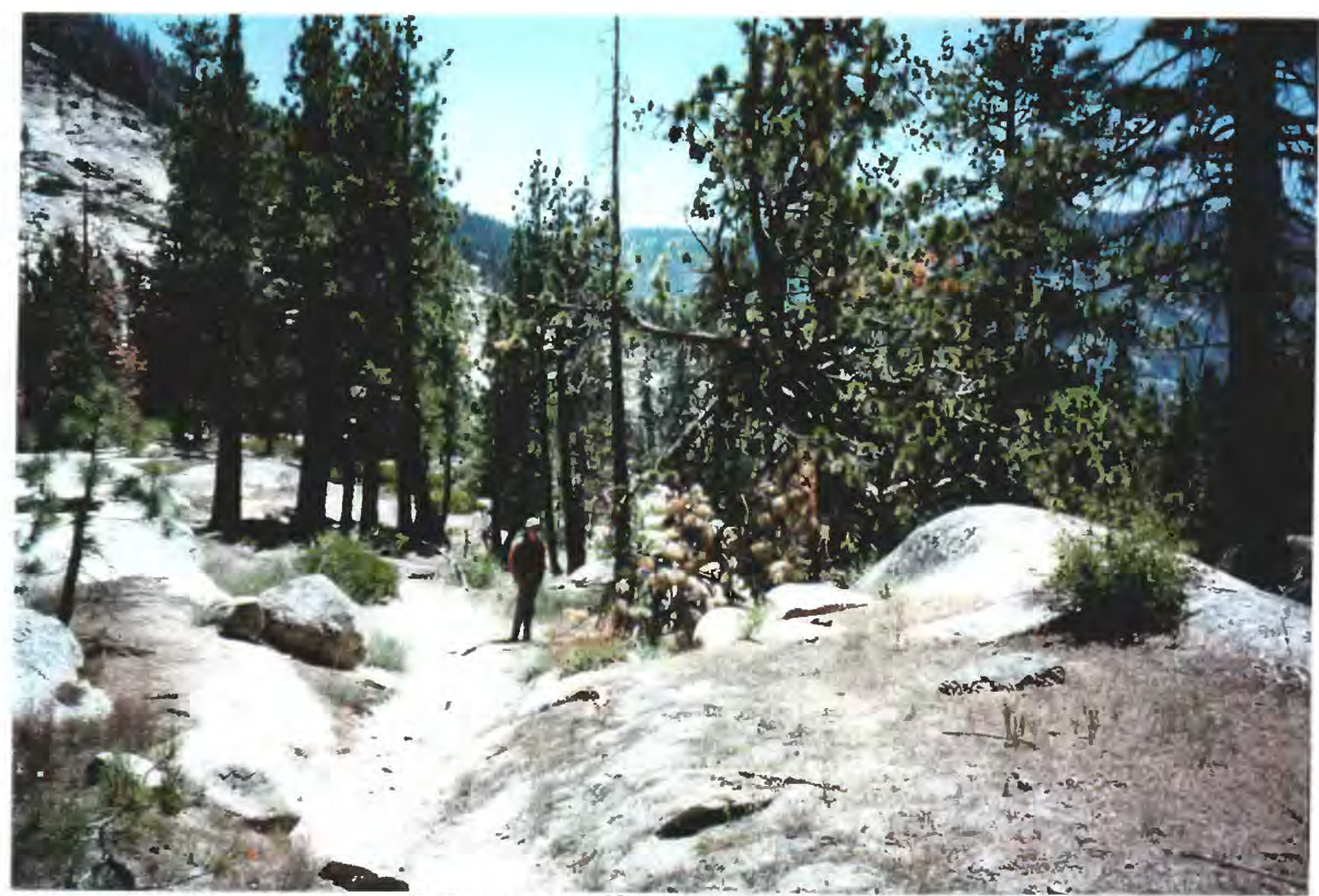

Photo 15.1 - View toward the south from turnoff on trail.

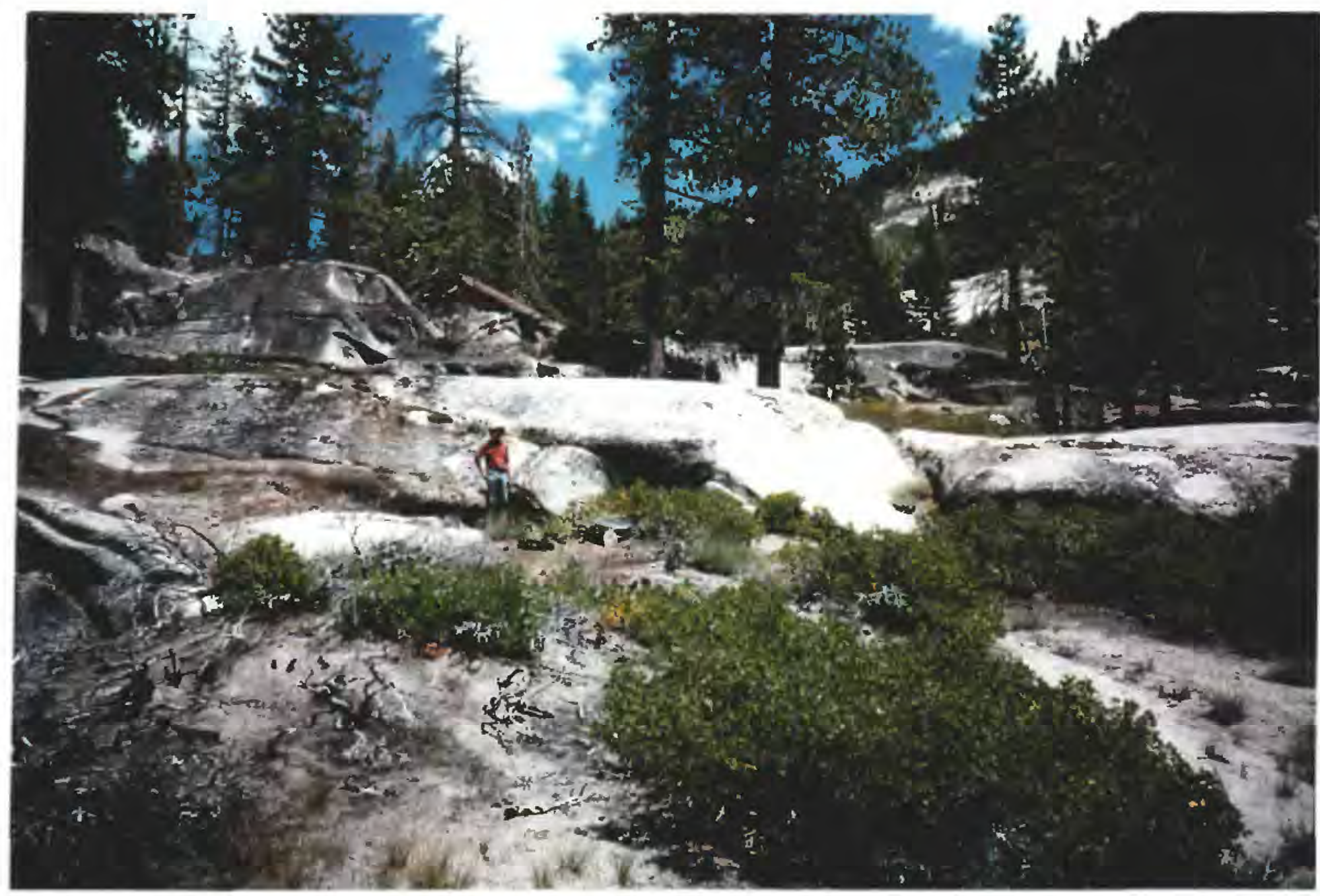

Photo 15.2 - View of station, looking NE.

MM15 Cold Creek: About 630 meters after crossing Cold Creek by a log bridge, there is a large fallen tree to the right of the trail (Photo 15.1). This tree can also be seen in Photo 15.2. Leave the trail to the right (west) and walk downhill about 60 meters to the station (Photo 15.2). 


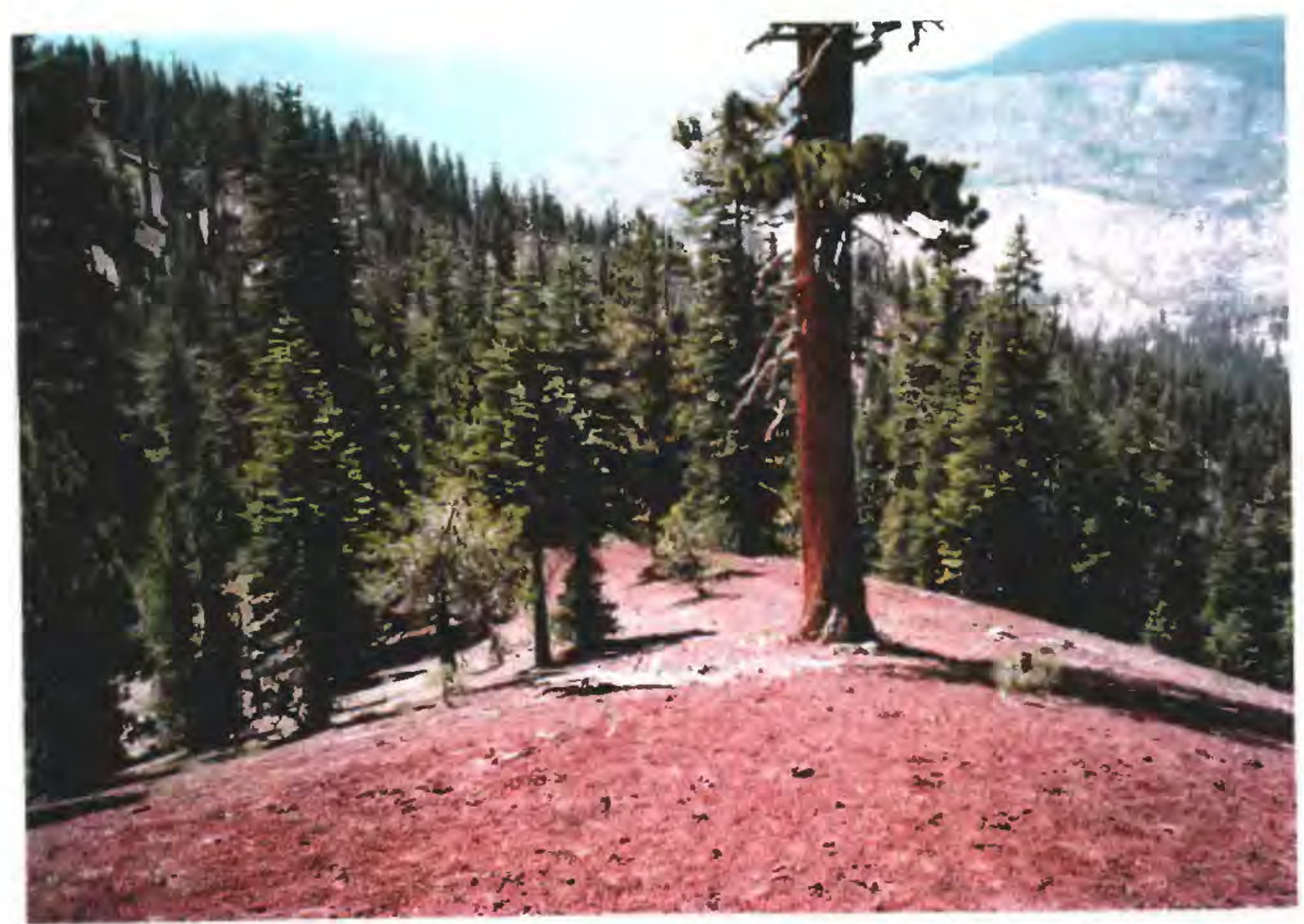

Photo 17.1 - View looking SSW on west side of northern Red Cone.

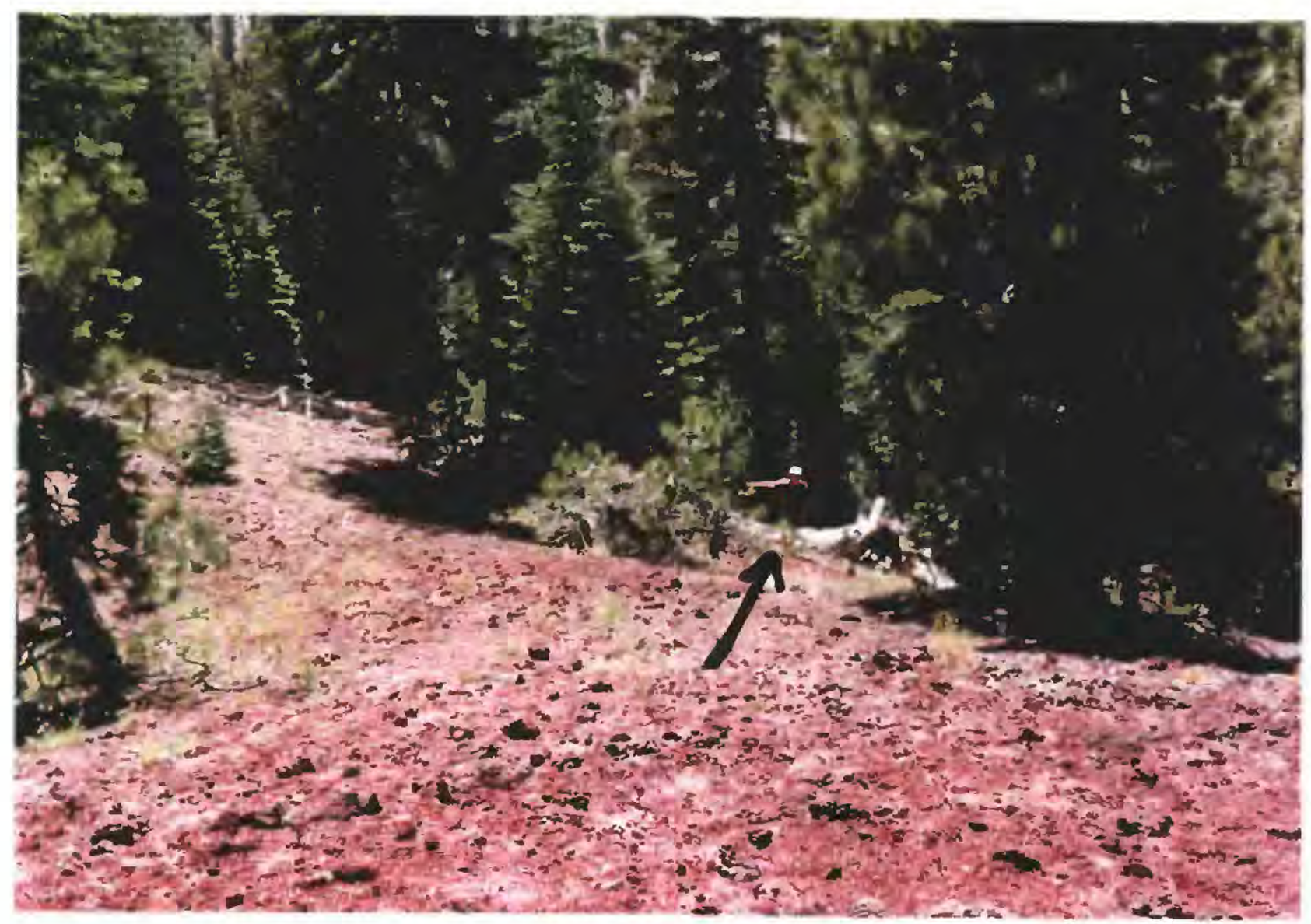

Photo 17.2

MM17 Red Cones: On arriving at the northern cone, leave the trail to the right and walk around the summit of the cone on the north side. Photo 17.1 shows the view when walking south along the western rim as you approach the station. Photos 17.2 and 17.3 show close views of the station location, which was below the rim of the cone on the SW side, below a big tree near a fallen tree. 


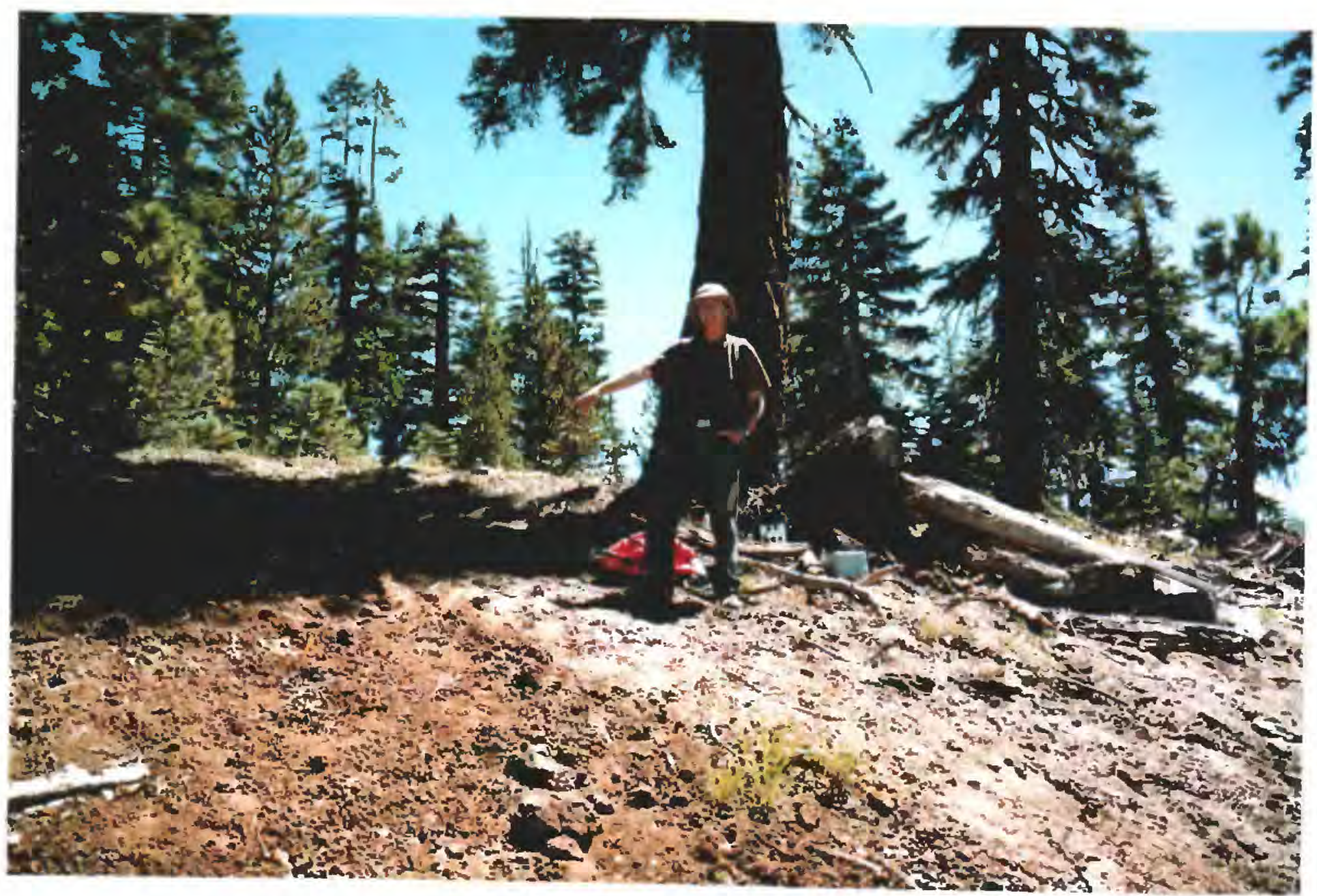

Photo 17.3 - View of station site, looking east. 


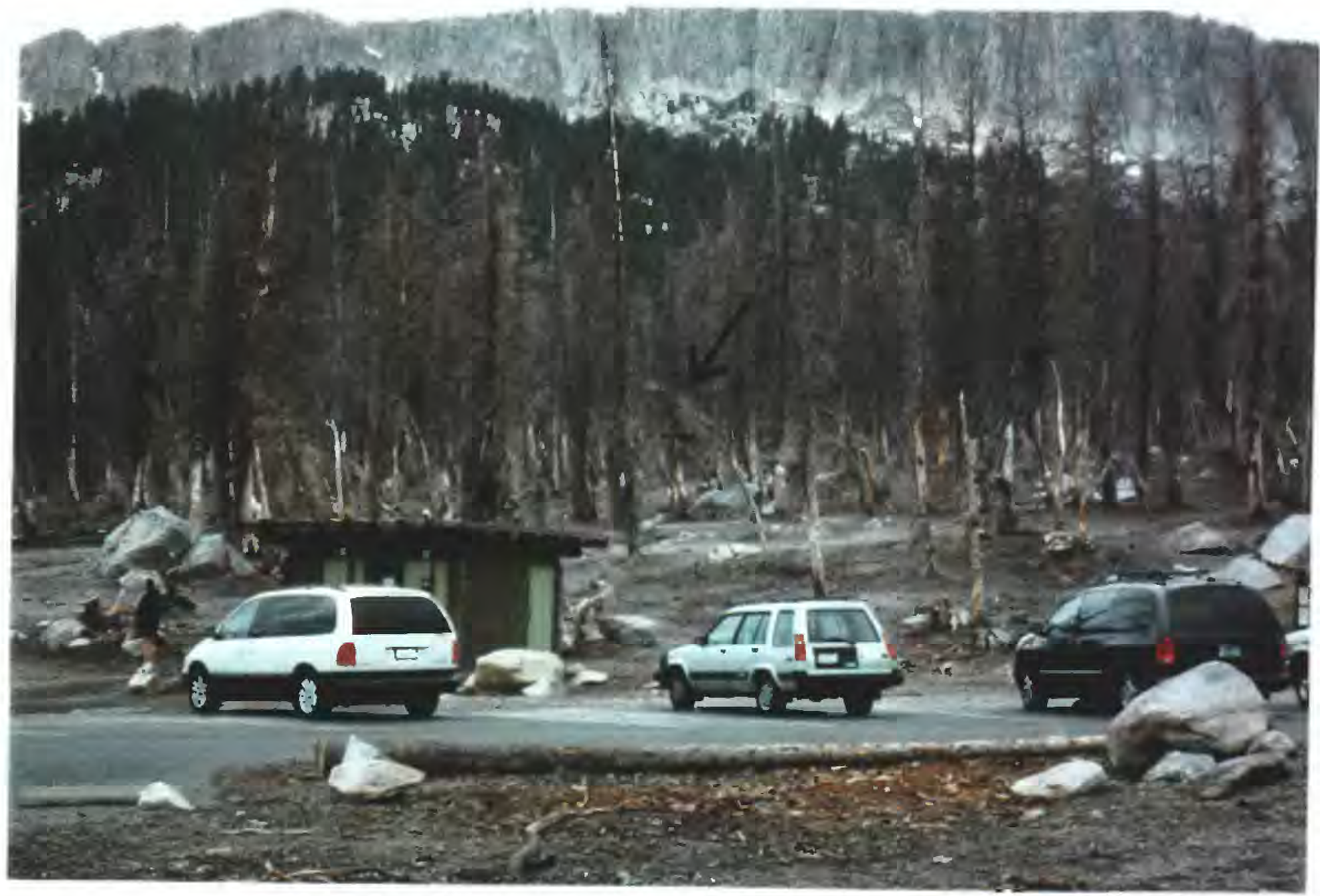

Photo 18.1 - View looking SW from parking lot.

MM18 Horseshoe Lake: Station was in small, broken-down, green-roofed Forestry Service shack in dead trees SW of public toilets (Photo 18.1). 


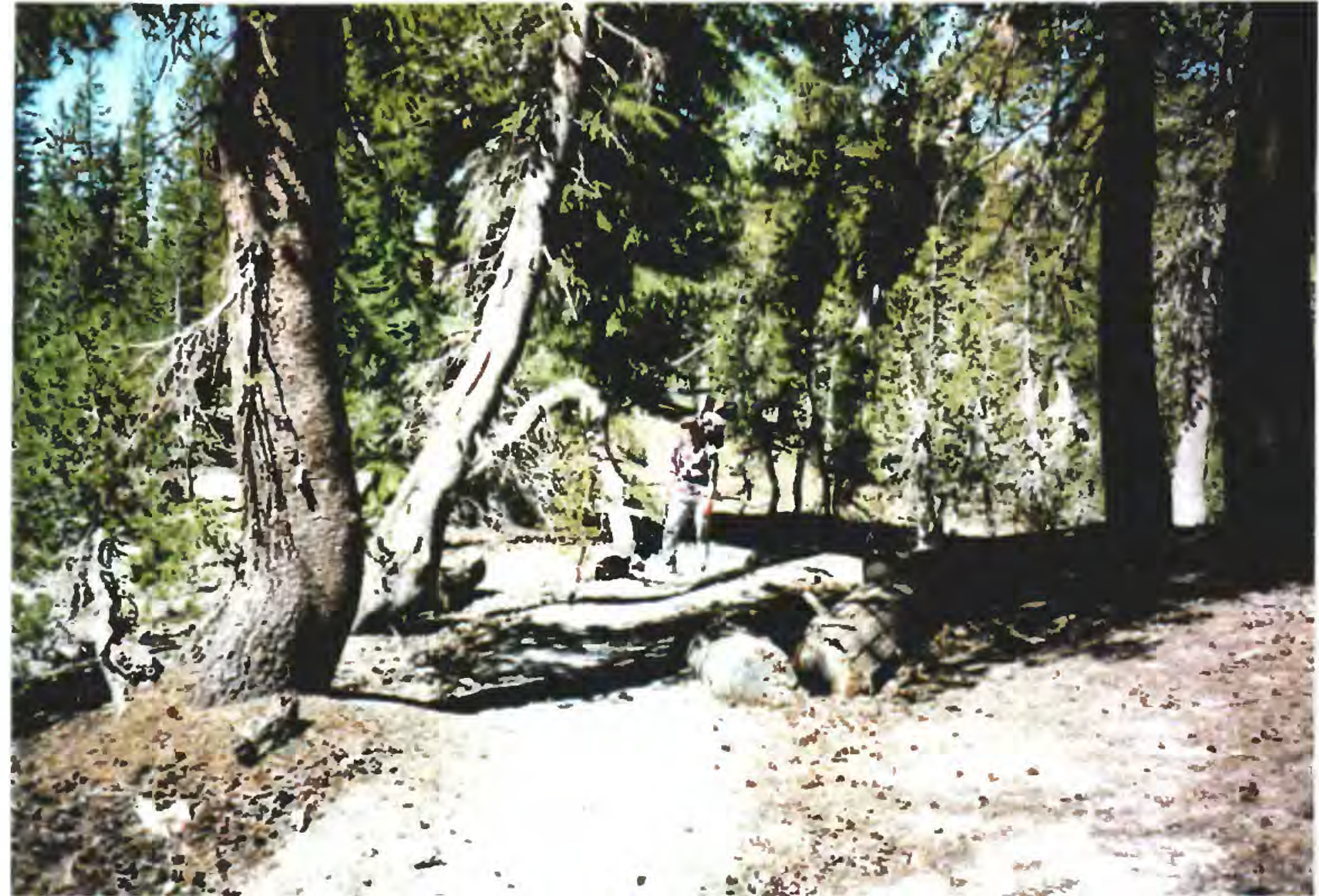

Photo 19.1 - View looking west along trail. Note "dog-legged" tree.

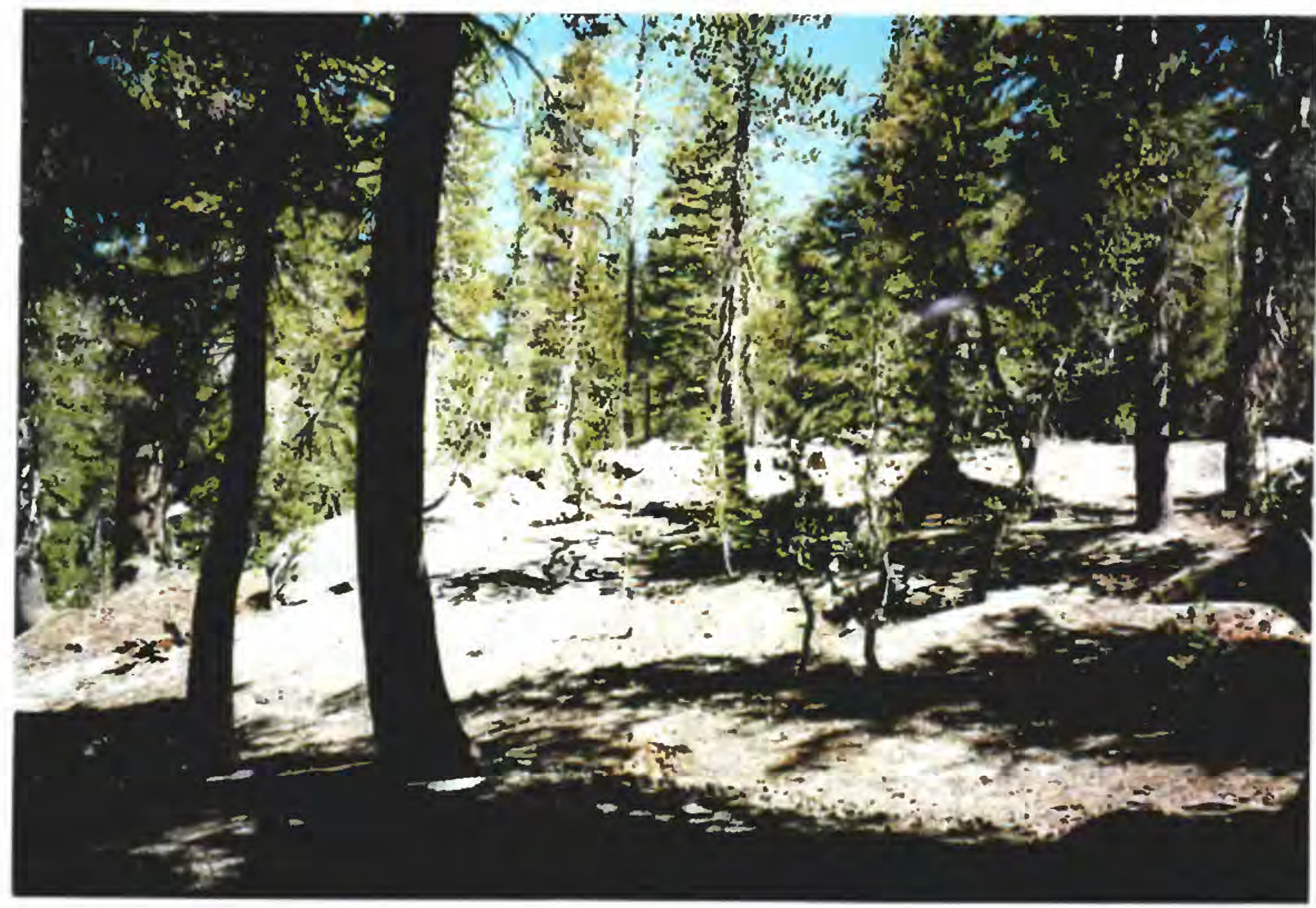

Photo 19.2 - View looking northwest from the trail. Station is on far side of outcrop.

MM19 Boundary Creek: The station is in nondescript forest. Basalt outcrops appear when you near the station, and the trail begins to slope downhill. A distinctive dog-legged tree grows on the south side of the trail (Photo 19.1). Walk up the slope on the right (north) for about 50 meters (Photo 19.2). The station was on an outcrop just over the crest of the slope (Photos 19.3 \& 19.4). 


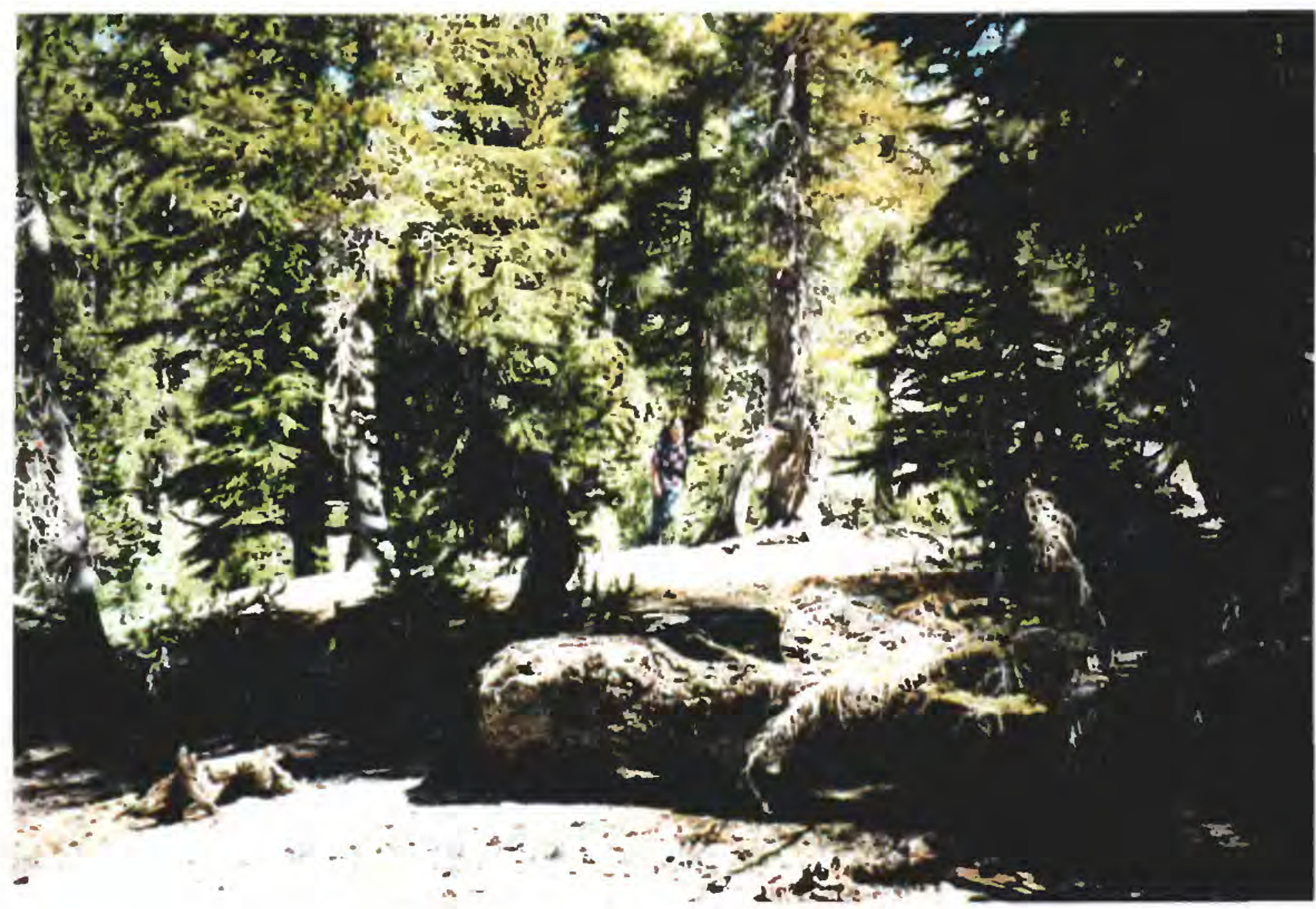

Photo 19.3 - View of station, looking to the north.

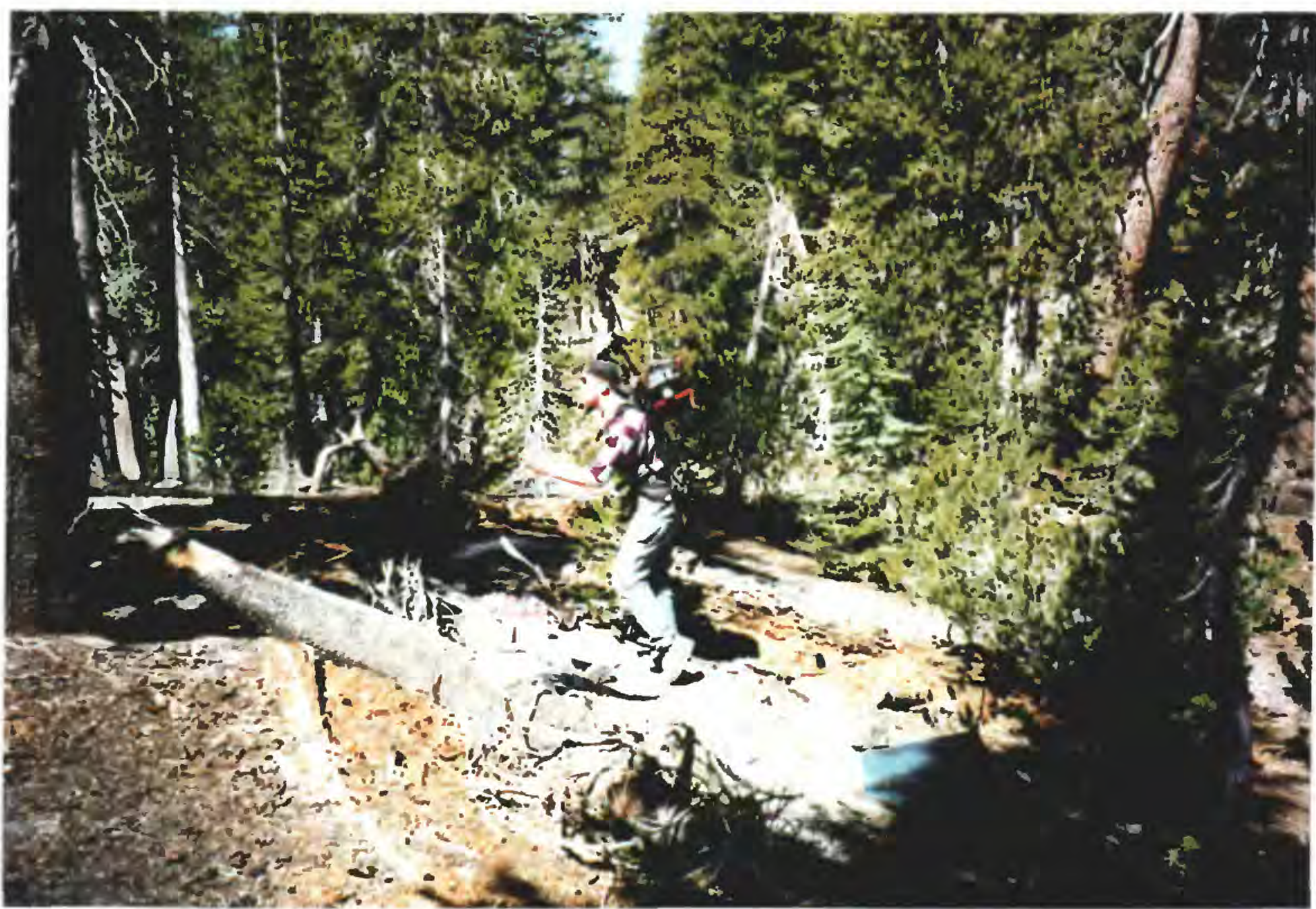

Photo 19.4 - View of station, looking to the west. 


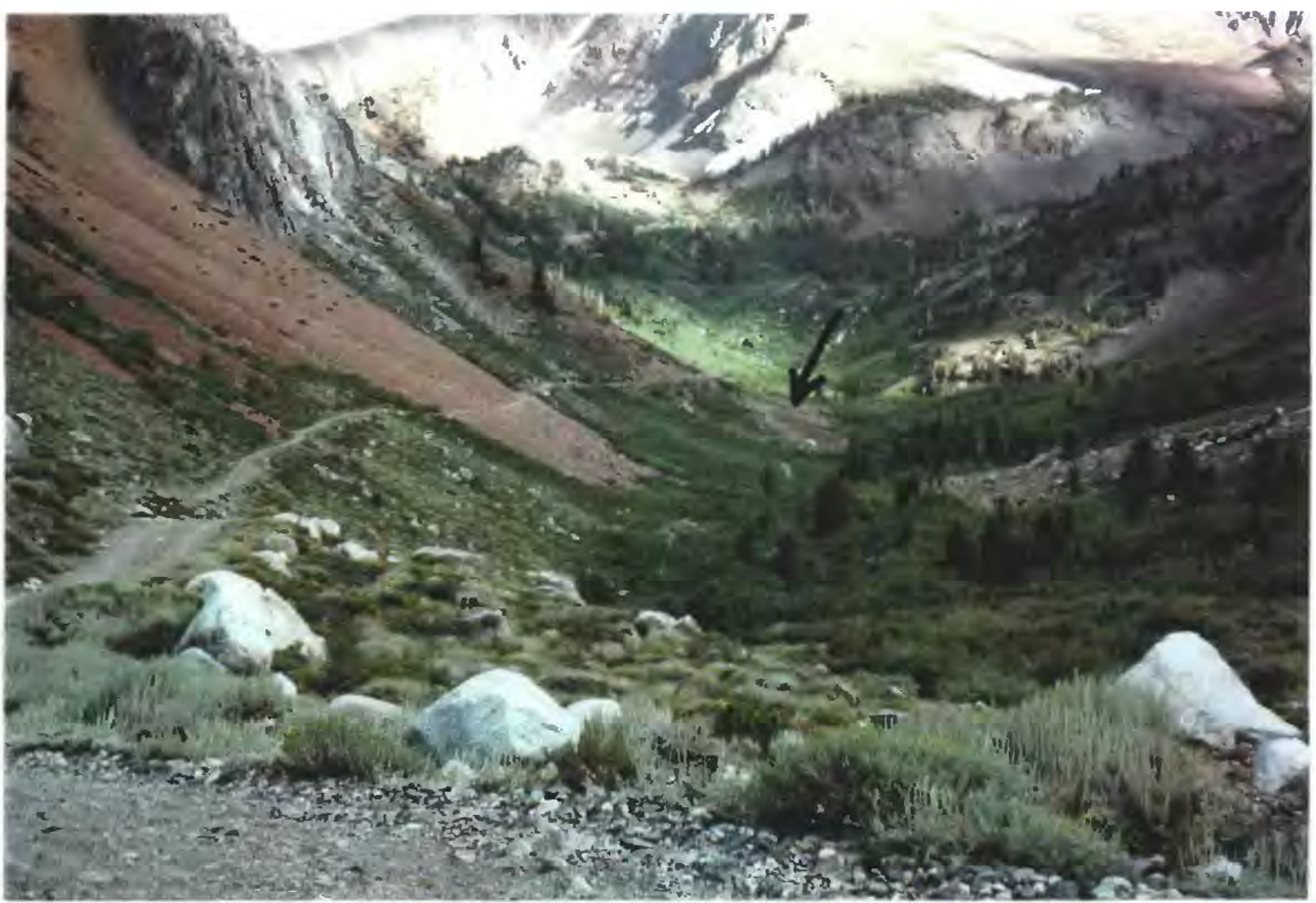

Photo 20.1 - View looking to the SSE toward station. Note red talus slope.

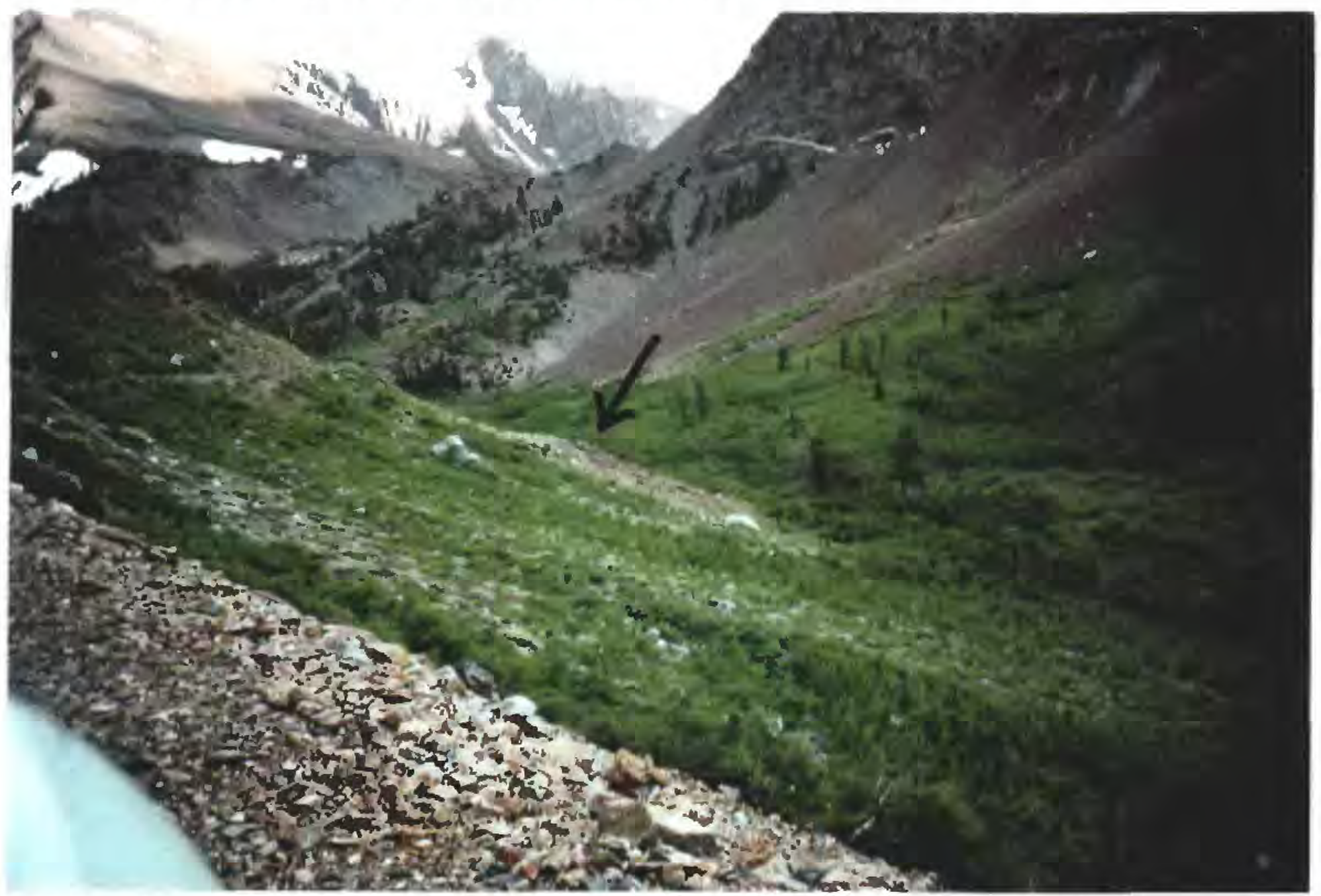

Photo 20.2 - View looking to the SSE toward station, which is on outcrop marked by arrow.

MM20 Laurel Canyon: Drive along rocky 4WD road for about 30 mins until you cross a reddish talus slope (Photo 20.1). The station was on a substantial outcrop about 30 meters below the road (Photo 20.2). Bruce is seen standing by the OMEGA antenna in Photo 20.3. 


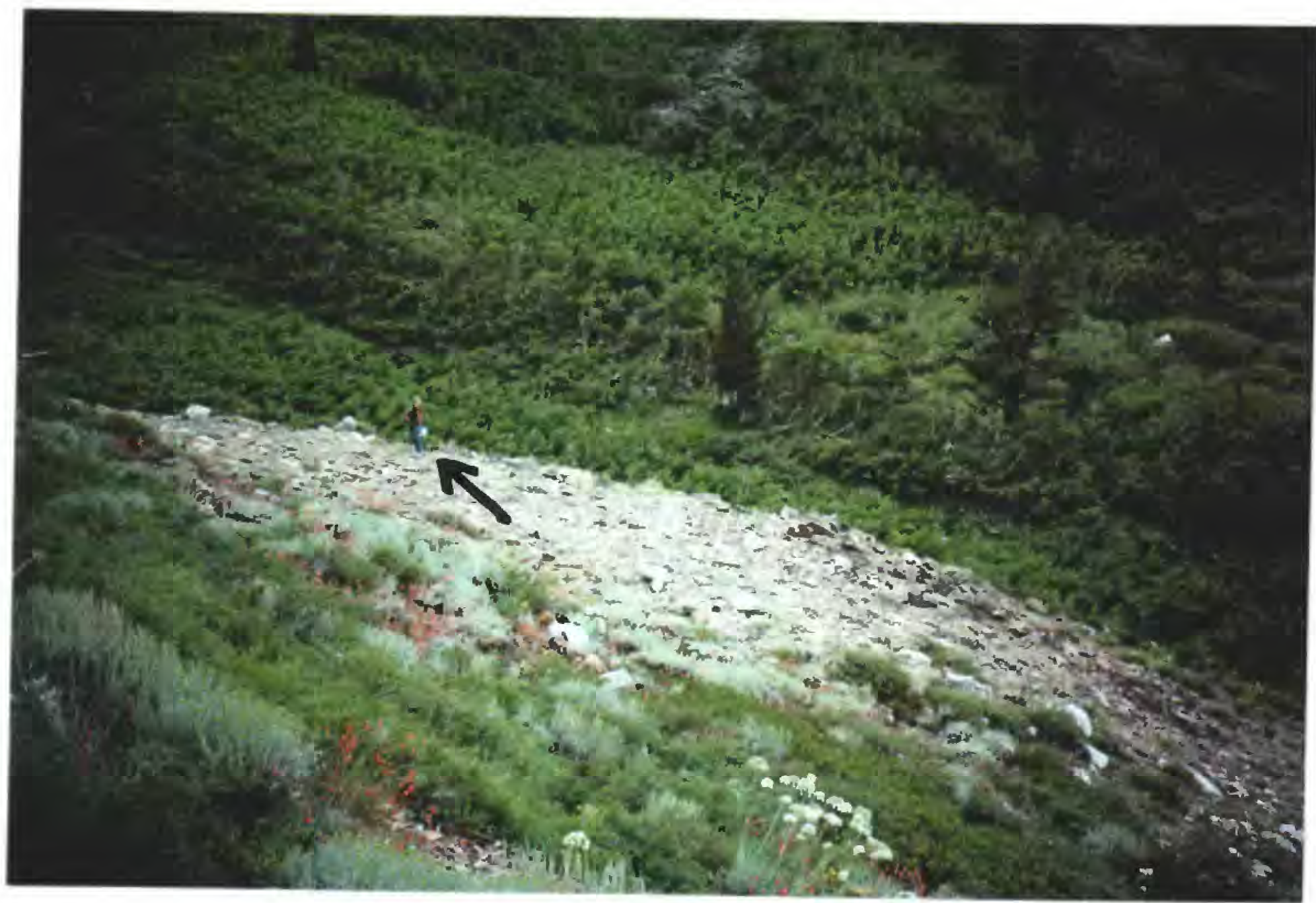

Photo 20.3 - View of station, looking to the SW from the road. 


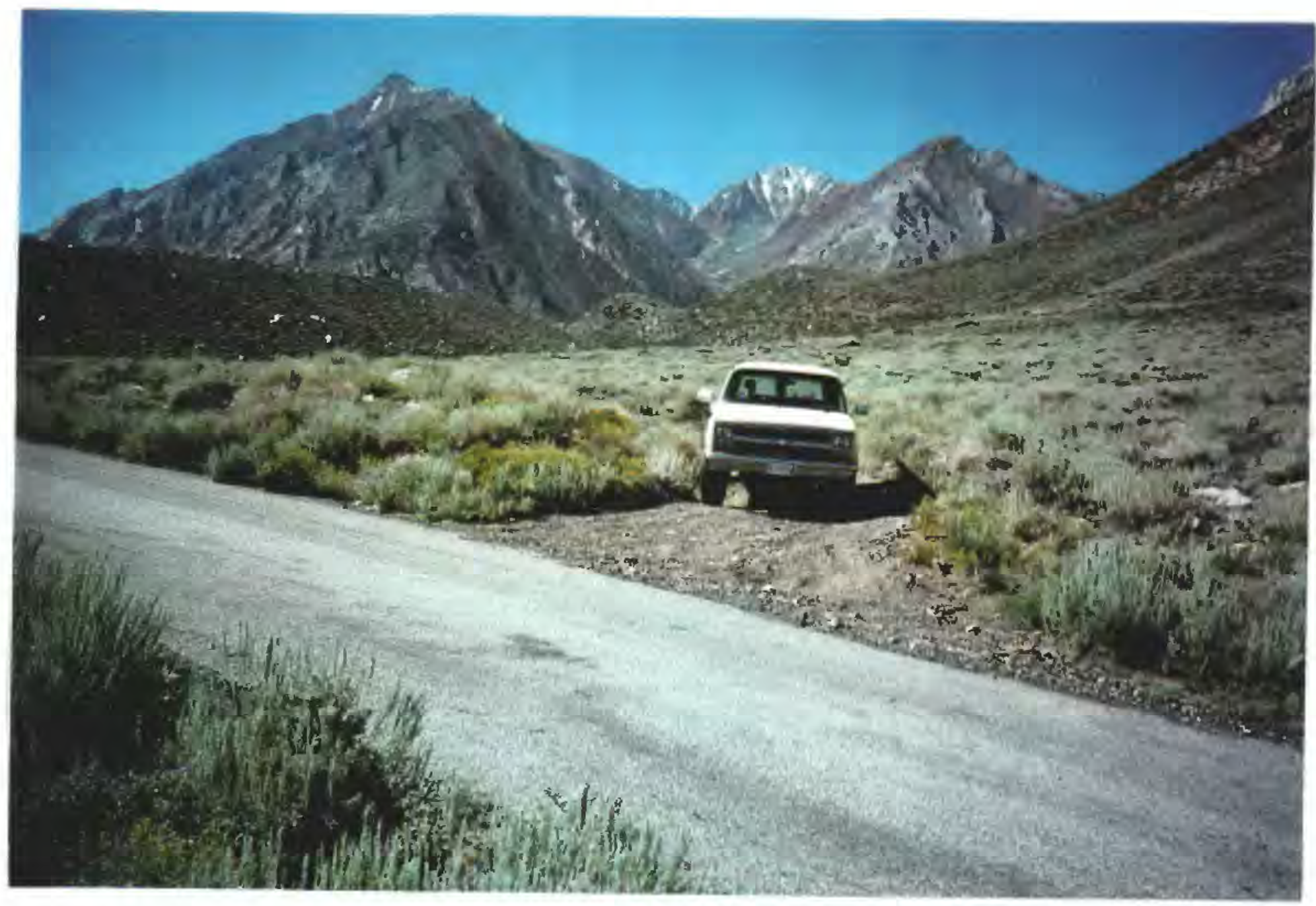

Photo 21.1 - View looking to the south from turnoff onto dirt road toward station.

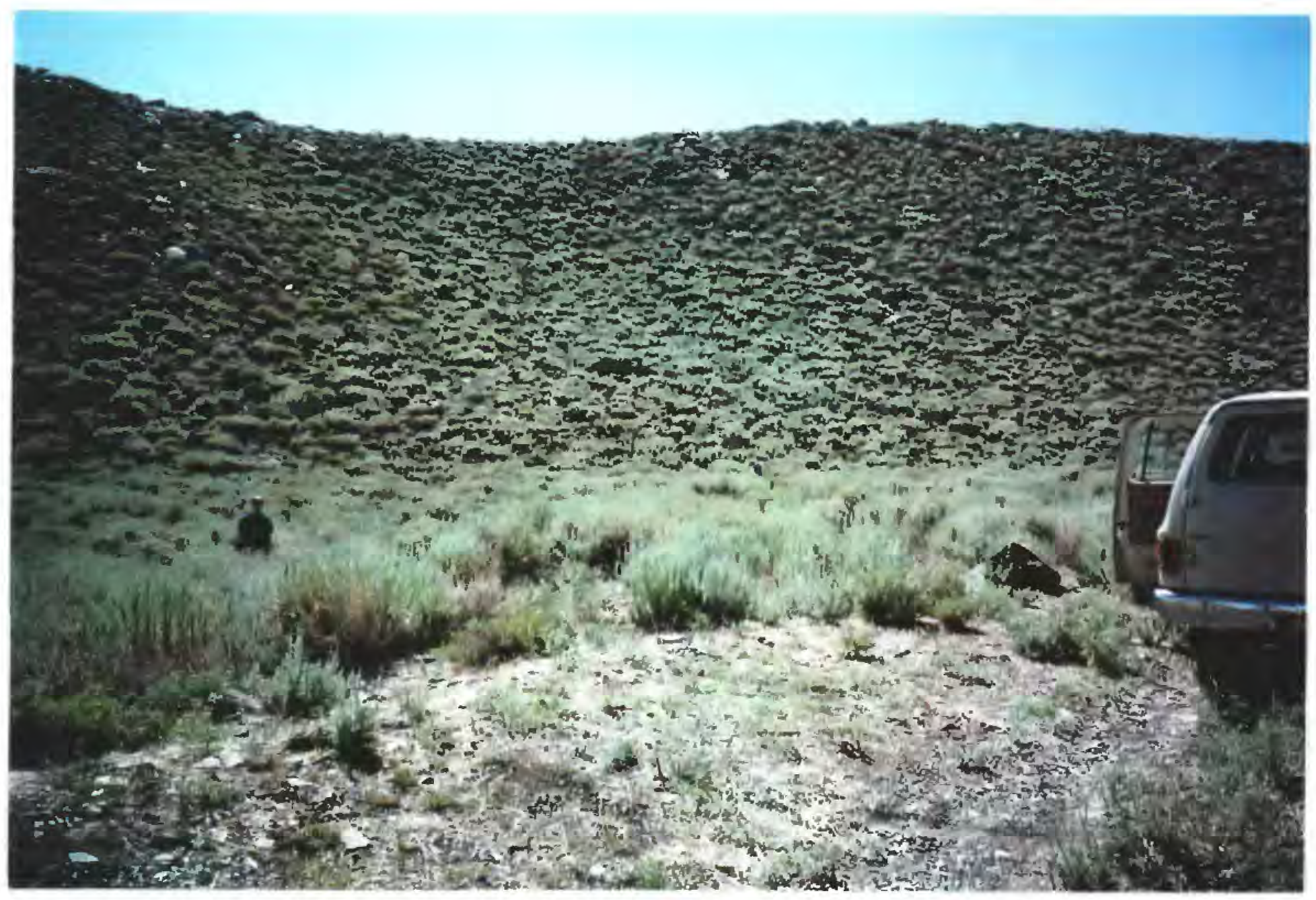

Photo 21.2 - View looking to the SE from dirt road. Becky is standing at the station.

MM21 McGee Moraine: From right turn on dirt trail (Photo 21.1), drive south 180 meters. Station was about 20 meters into the sagebrush on the east (Photos 21.2 \& 21.3). 


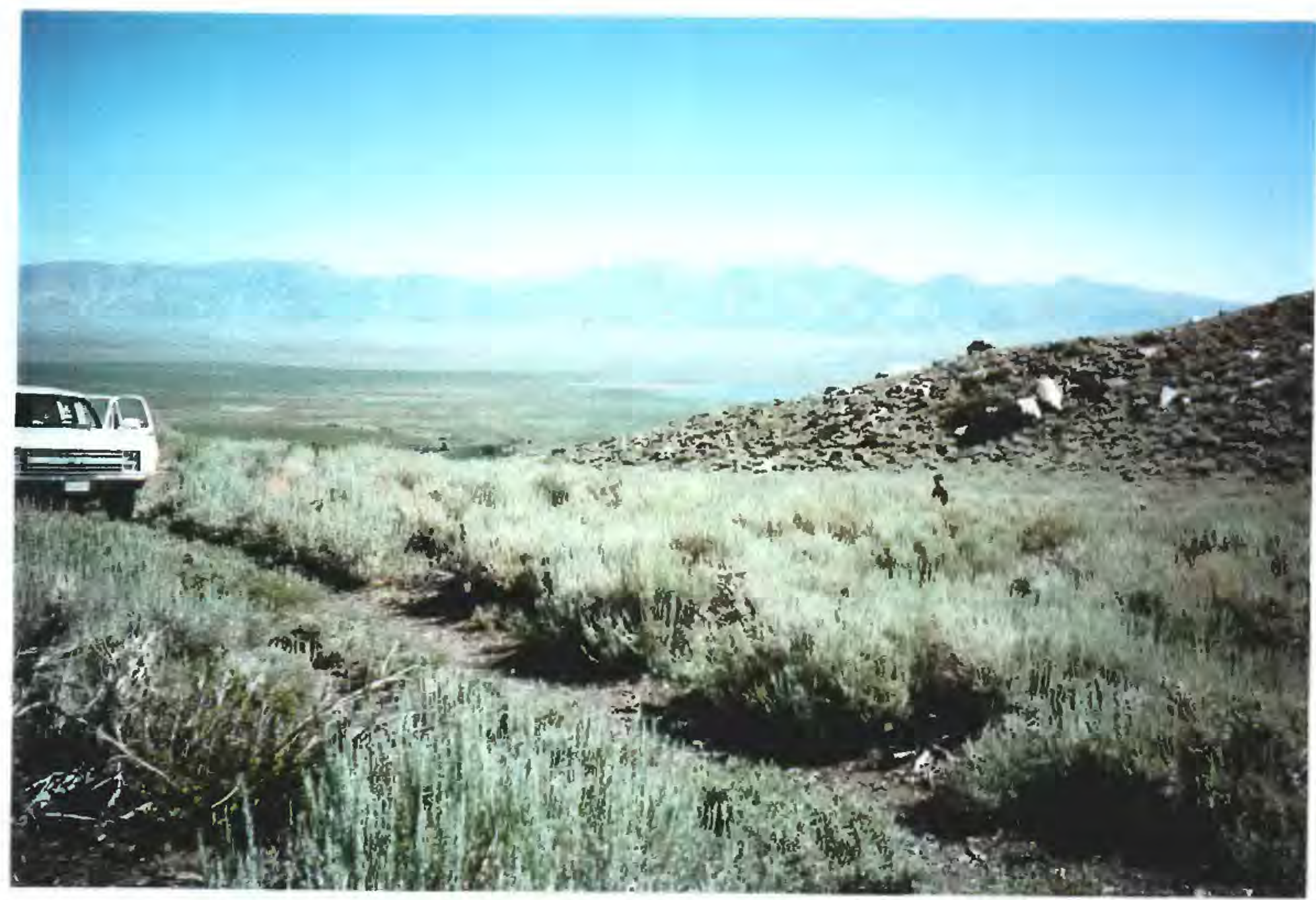

Photo 21.3 - View looking to the NE from dirt road. Gillian is standing at the station. 


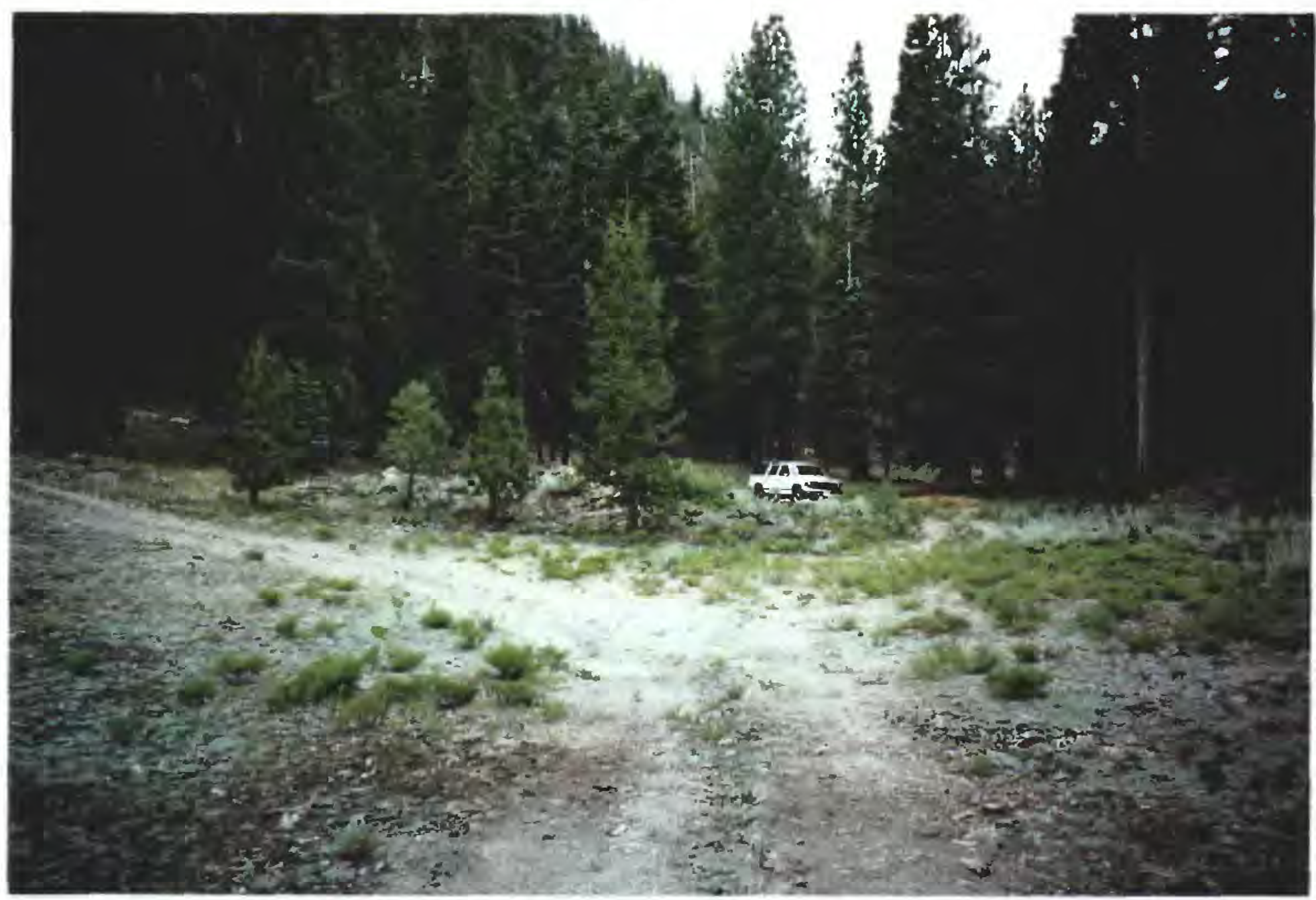

Photo 22.1 - View looking to the SW from "very indistinct fork" on dirt road.

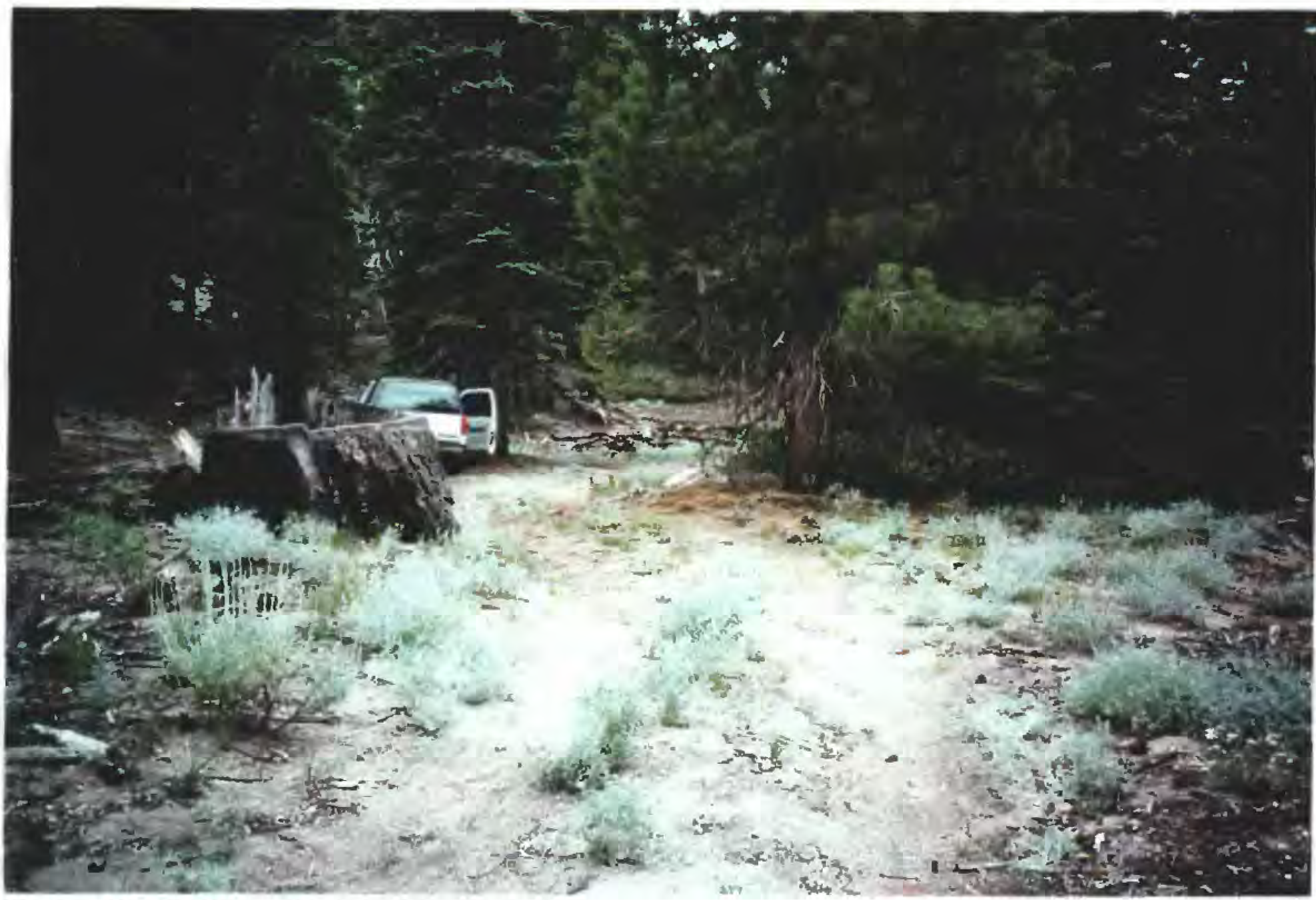

Photo 22.2 - Parking spot beyond tree stump.

MM22 Dry Creek: Drive along dirt road until it bends left and starts to climb steeply. Do not bend left but go straight (SW) at indistinct fork onto indistinct 4WD trail (Photo 22.1). Continue $0.16 \mathrm{~km}(0.1 \mathrm{mi})$ up gentle slope and park just beyond tree stump (Photo 22.2). Sensor was buried at base of large boulder/outcrop where Dave is pointing (Photo 22.3). 


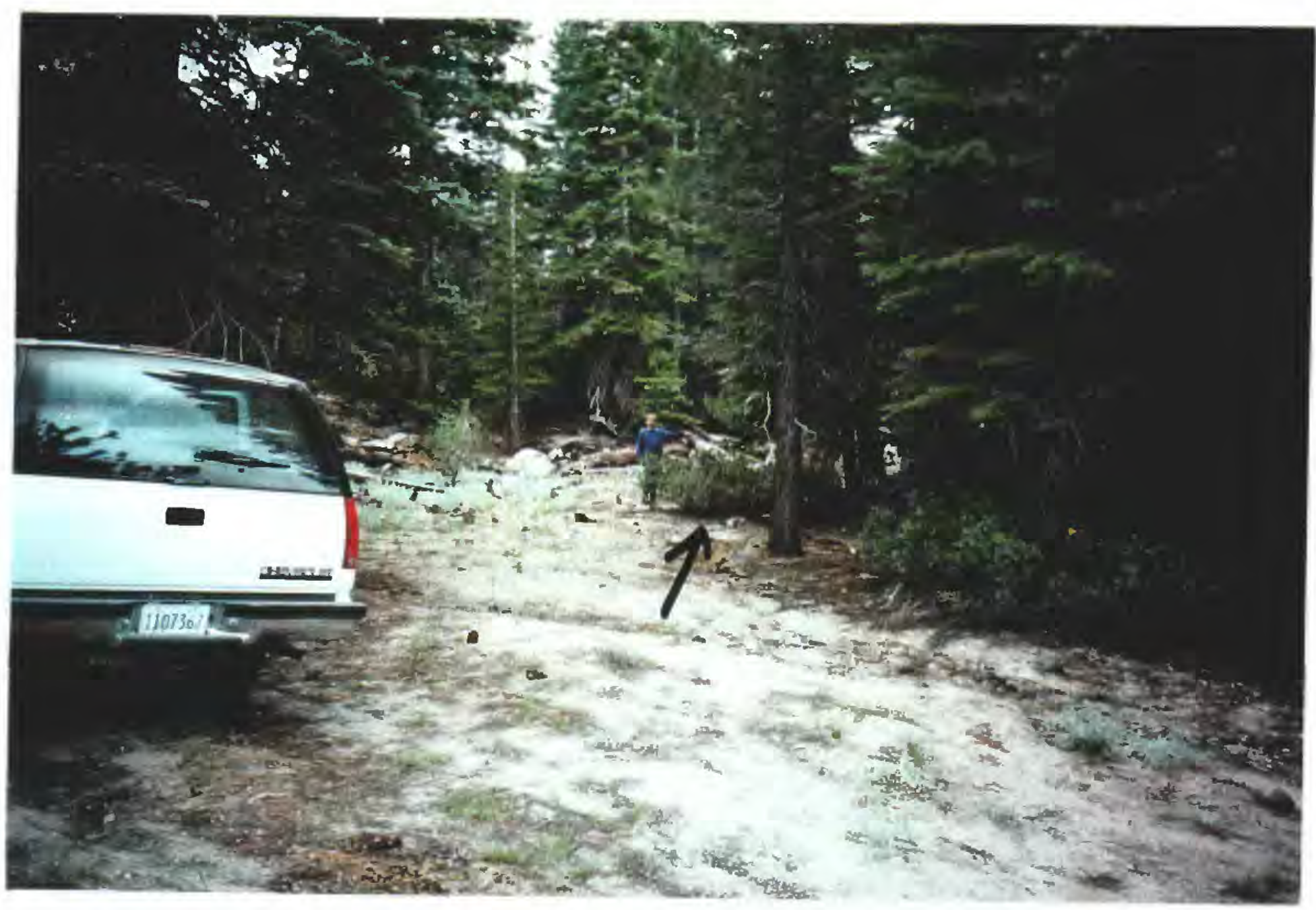

Photo 22.3

MM22 Dry Creek (continued). 


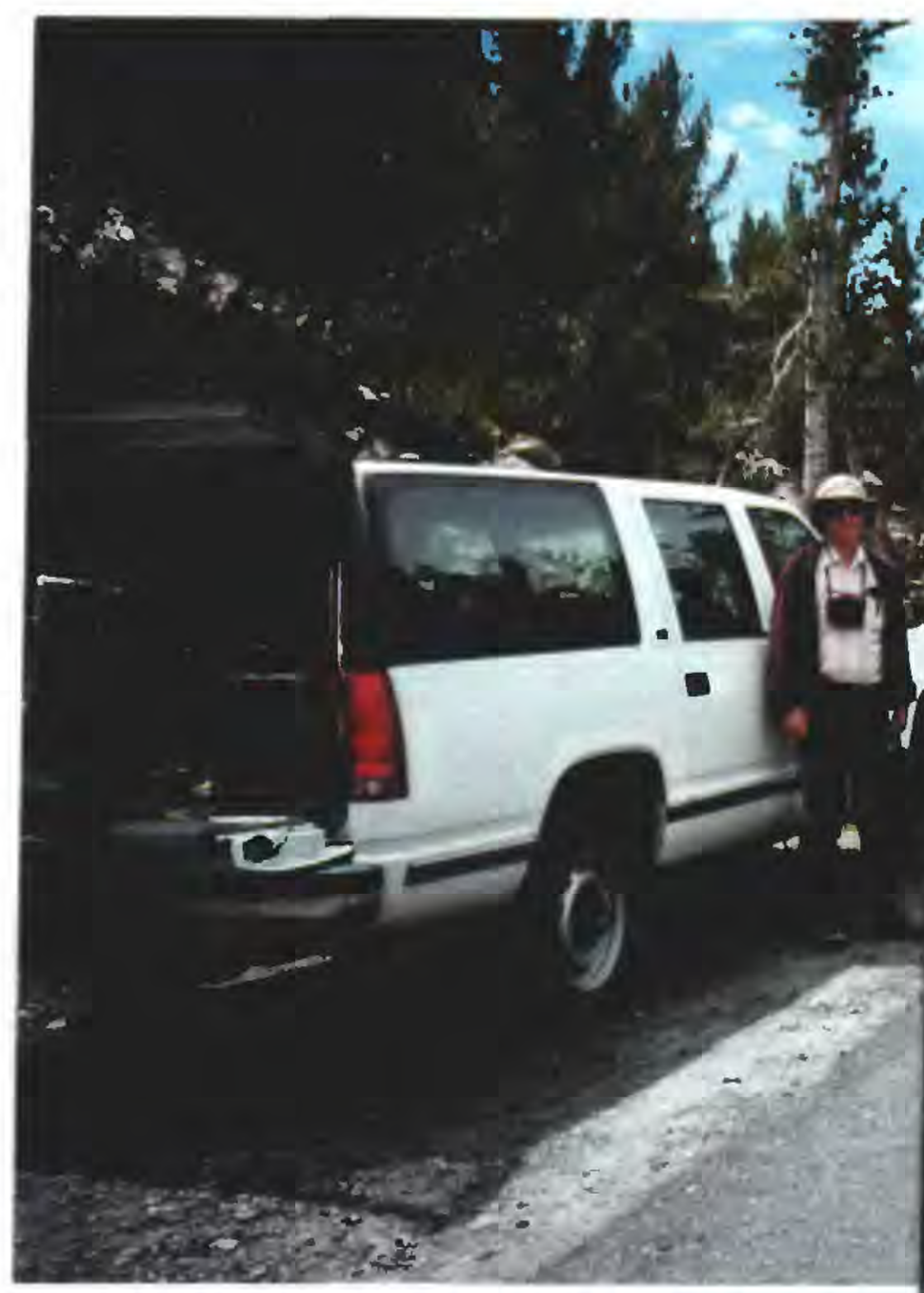

Photo 23.1 - View looking to the south, showin

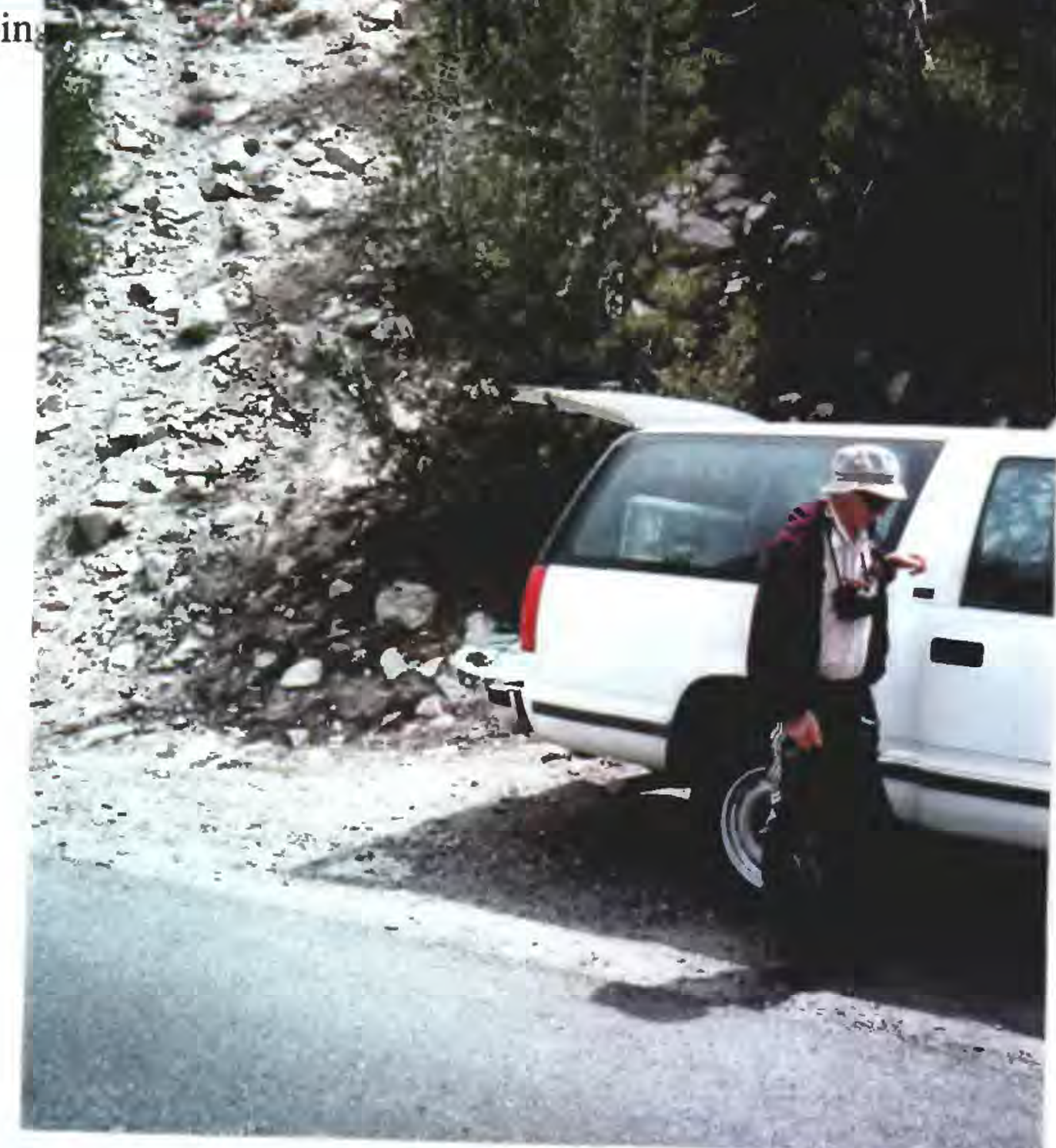

Photo 23.2 - View looking to the east from (No) parking spot, up steep slope toward station.

MM23 Upper Rock Creek: Park either by "No Parking any time" sign on bridge (Photo 23.1), or, if you are chicken, in the car park about 100 meters north. Scramble up steep slope just north of bridge on east side of road (Photo 23.2). Station was located on outcrop near the top of the slope (Photo 23.3, over). 


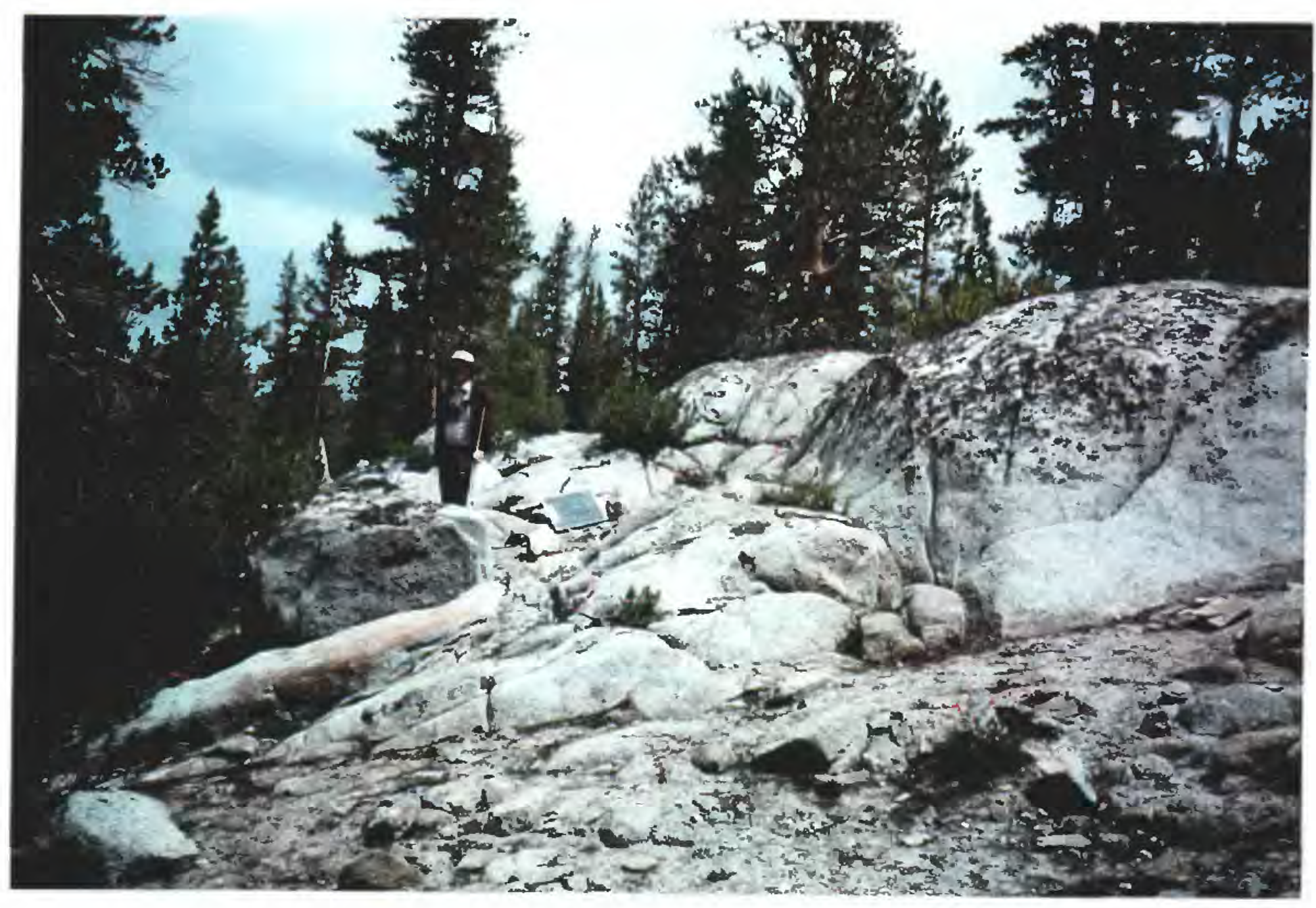

Photo 23.3 - View of station, looking to the north. 


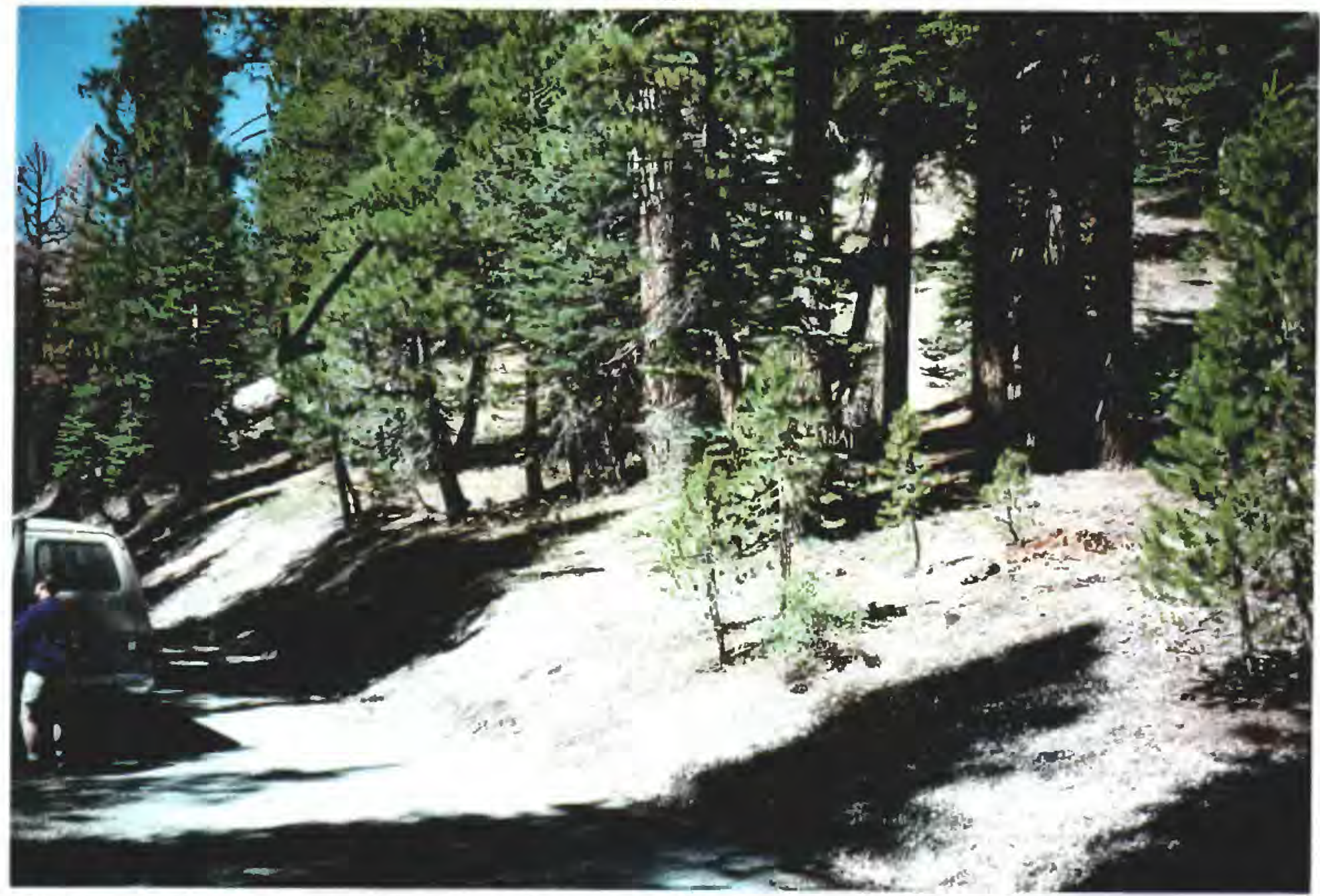

Photo 24.1 - Parking spot on Deadman Creek Rd. View to the NNW. Note boulder.

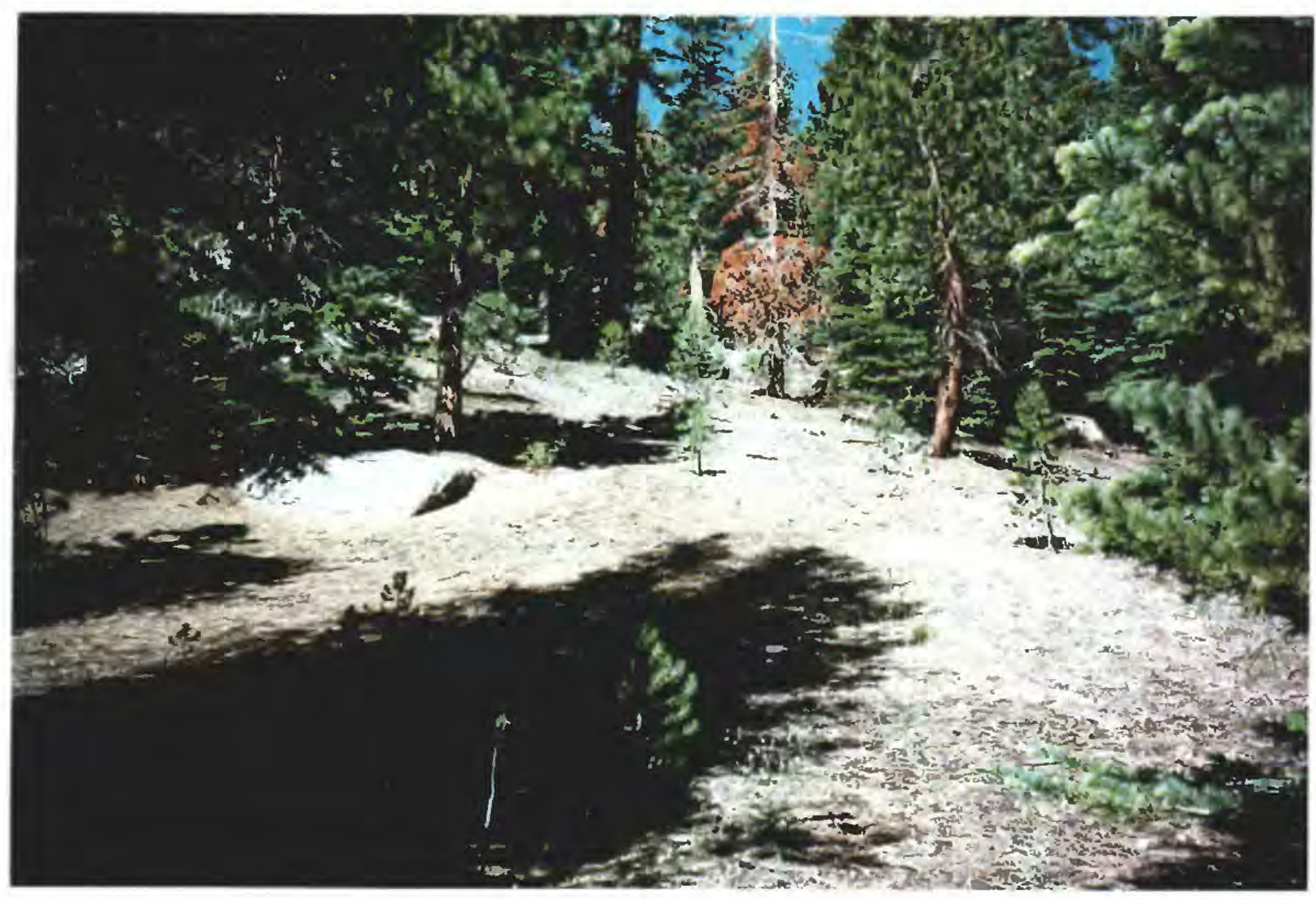

Photo 24.2 - Hillside below station. View looking to the north.

MM24 Deadman Creek: Drive east along Deadman Creek Rd. the distances given on the map description. Park on the road just below a steep hillside on the right (NE). A rare boulder can be seen through the trees (Photo 24.1). Walk north up the hillside about 50 meters (Photo 24.2) to an outcrop. The sensor was located just below an NCSN vault (Photo 24.3). 


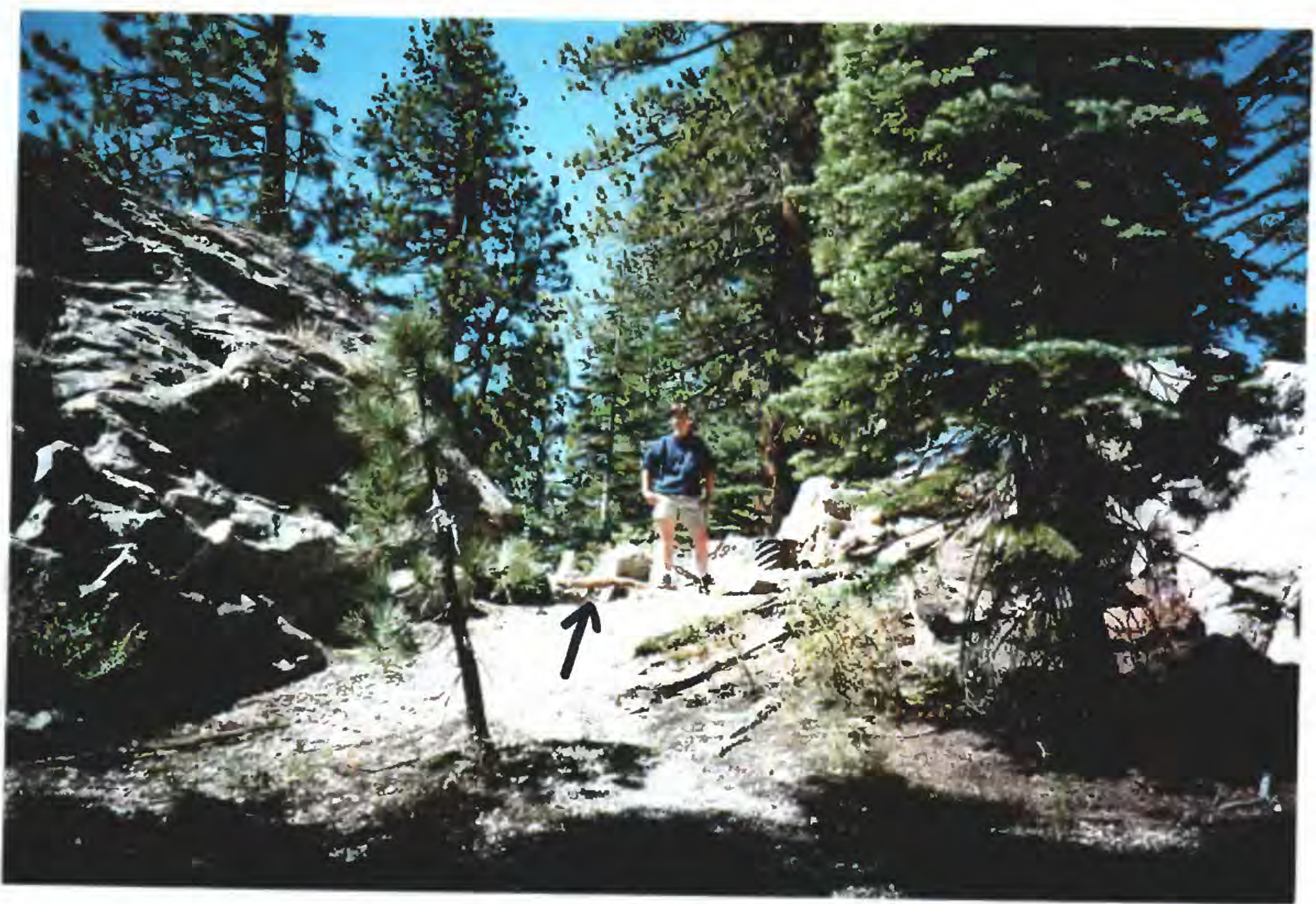

Photo 24.3 - Station, Gillian, and NCSN vault. View looking to the WNW. 